\title{
HEDGE FUNDS AND \\ THEIR IMPLICATIONS FOR \\ FINANCIAL STABILITY
}

by Tomas Garbaravicius

and Frank Dierick 
EUROPEAN CENTRAL BANK

OCCASIONAL PAPER SERIES

N0. 34 I AUGUST 2005

HEDGE FUNDS AND

THEIR IMPLICATIONS FOR

FINANCIAL STABILITY*

by Tomas Garbaravicius
and Frank Dierick

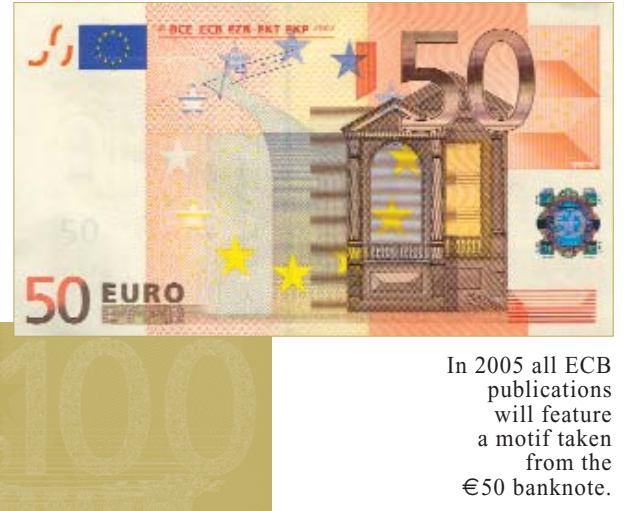

This paper can be downloaded without charge from the ECB's website (http://www.ecb.int) or from the Social Science Research Network electronic library at http://ssrn.com/abstract_id=752094.

\footnotetext{
The authors work in the Directorate Financial Stability and Supervision of the ECB. They are grateful for comments received from Inês Cabral, John Fell, Mauro Grande and Panagiotis Strouzas. All remaining errors and omissions are those of the authors. The views expressed in this paper are the authors' and do not necessarily reflect those of the $E C B$ or the Eurosystem.
} 
() European Central Bank, 2005

\section{Address}

Kaiserstrasse 29

60311 Frankfurt am Main

Germany

Postal address

Postfach 160319

60066 Frankfurt am Main

Germany

Telephone

+496913440

Website

http://www.ecb.int

Fax

+496913446000

Telex

$411144 \mathrm{ecb} d$

All rights reserved. Reproduction for educational and non-commercial purposes is permitted provided that the source is acknowledged.

The views expressed in this paper do not necessarily reflect those of the European Central Bank.

ISSN 1607-1484 (print)

ISSN 1725-6534 (online) 


\section{CONTENTS}

ABSTRACT

\section{EXECUTIVE SUMMARY}

I INTRODUCTION

2 THE CONCEPT OF HEDGE FUNDS

3 TYPOLOGY OF HEDGE FUNDS

4 CHARACTERISTICS OFTHE HEDGE FUND INDUSTRY

4.1 Location of hedge funds and their managers

4.2 Incentive structure and failure rates

4.3 Parties involved

4.4 Investors

4.5 Fund size

5 RECENT EVOLUTION OFTHE HEDGE FUND BUSINESS

6 FINANCIAL STABILITY IMPLICATIONS 25

6.1 Possible positive effects 25

6.2 Possible negative effects 27

6.2.1 Through leverage and liquidity risks of hedge funds 28

6.2.2 Through impact on credit institutions

6.2.3 Through impact on financial markets IMPLICATIONS

7.1 Risk management practices

7.2 Disclosure, transparency and the valuation of positions

7.3 Sound business practices

7.4 Regulatory issues

8 CONCLUSIONS $\quad 55$

\section{ANNEXES}

A Evolution of the hedge fund industry

B Major international initiatives to address concerns related to hedge funds

\section{Conventions used in the tables}

“-” data do not exist/data are not applicable/ data not available to authors

“." data are not yet available

“... nil or negligible 


\section{ABSTRACT}

The paper provides an overview of the hedge fund industry, mainly from a financial stability and European angle. It is primarily based on an extensive analysis of information from the TASS database. On the positive side of the financial stability assessment, hedge funds have a role as providers of diversification and liquidity, and they contribute to the integration and completeness of financial markets. Possible negative effects occur through their impact on financial markets (e.g. via crowded trades) and financial institutions (e.g. via prime brokerage). Several initiatives have been launched to address these concerns and most of them follow indirect regulation via banks. If any direct regulation were to be considered, it would probably have to be implemented in a coordinated manner at the international level. At the EU level there is currently no common regulatory regime, although some Member States have adopted national legislation.

Key words: asset management, crowded trades, financial regulation, financial stability, hedge funds, prime brokerage, risk management.

JEL classification: G15, G18, G21, G23, G24 


\section{EXECUTIVE SUMMARY}

This paper provides an overview of the hedge fund industry, mainly from a financial stability angle and with an emphasis on its European Union (EU) dimension. Hedge funds still represent a relatively small share of the asset management industry. Nevertheless they have been growing impressively, with total capital under management now estimated to be over USD 1 trillion globally. Their active role in financial markets means that they are much more important than suggested by their size alone. These developments have ensured that hedge funds have the continued attention of public authorities and the financial community, the more so since there remains a large degree of uncertainty regarding the implications for financial stability.

Although there is no common definition of what constitutes a hedge fund, it can be described as an unregulated or loosely regulated fund which can freely use various active investment strategies to achieve positive absolute returns. Typically, the fees of fund managers are related to the performance of the fund in question and managers often commit their own money. Although the investment strategy, by definition, varies widely, hedge funds can be broadly classified as directional, market neutral or event driven funds. Although they typically target high net worth individuals and institutional investors, their products have recently become increasingly available to retail investors due to the development of funds investing in hedge funds and structured financial instruments with hedge fund-linked performance. A multitude of parties are involved in the operation of such funds: managers, administrators, custodian banks, prime brokers, investors, etc. Some of these roles are also being assumed by banks, and more banks are seen to be setting up their own hedge funds.

Hedge funds are primarily domiciled in offshore centres because of the ensuing light regulatory treatment and favourable tax regimes. Most hedge funds are relatively small, with capital under management of less than USD 100 million, although this varies according to the investment strategy applied. EU hedge funds, i.e. funds domiciled in the EU and/or with managers residing in the EU, are mainly established in Luxembourg and Ireland and their managers are generally based in London. The market share of EU hedge funds have continued to expand, mainly at the expense of funds managed from the United States.

It is challenging to make an unambiguous assessment of the impact of hedge funds on financial stability, not least because of the lack of complete information on their activity, financial structure and interaction with banks. As active market participants they often take contrarian positions, thus contributing to market liquidity, dampening market volatility and acting as a counterbalance to market herding. In addition, they offer diversification possibilities and allow new risk-return combinations to be achieved, leading to more complete financial markets. It can also be argued that by eliminating market inefficiencies hedge funds have probably contributed to the integration of financial markets.

The near-collapse of LTCM in 1998 highlights how hedge fund activities can also seriously harm financial stability. Such negative effects basically occur through their impact on financial markets and financial institutions, in particular via banks that act as prime brokers or that take similar market positions as hedge funds. The management of banks' exposures to hedge funds is complex and requires continuous improvements and vigilance to keep up with developments. As the number of hedge funds attempting to exploit the same market opportunities increases, there are also concerns that this same positioning may seriously affect certain markets in the event of simultaneous selling. It is particularly challenging to assess how hedge funds affect and are being affected by the interaction of market risk, liquidity risk, credit risk and leverage. 
Since the near-default of LTCM, several public and private initiatives have been launched to address some of the concerns related to hedge funds. Most of these initiatives recognise that it is very difficult to regulate hedge funds directly given the ease with which they can change their domicile and avoid regulation. These initiatives therefore focus on indirect regulation which targets the counterparties of hedge funds, in particular banks. Such indirect regulation aims at enhancing risk management practices in banks and improving disclosure by hedge funds. If any direct regulation were to be considered, it would probably have to be implemented in a strongly coordinated manner at the international (transatlantic) level. Finally, as hedge funds become increasingly available to retail investors, though generally in an indirect way, there might also be a need to address investor protection concerns. At present there is no common regulatory regime for hedge funds in the EU, although a number of Member States have adopted national legislation.

\section{INTRODUCTION}

Hedge funds first came to prominence with the near-collapse of Long-Term Capital Management (LTCM) in September 1998. Recently, they have again started to attract the attention of the global financial community this time for their impressive growth and increasing proliferation as a mainstream alternative investment vehicle. Although the hedge fund industry is still relatively modest in size, the pace of growth indicates that hedge funds are heading towards becoming important non-bank financial intermediaries. However, while the role of other major institutional investors is well established, analysed and understood, the same is not true with regard to hedge funds, their activities, their impact on financial markets, and their implications for financial stability, all of which remain relatively less explored.

The purpose of this paper is to provide an overview of the hedge fund industry from a financial stability perspective, with some emphasis on the European Union (EU) dimension. The paper starts in Section 2 by providing a working definition of a hedge fund and by examining some of the key features of hedge funds. Hedge funds differ from each other in many respects, but their most notable distinguishing feature is the investment strategy they pursue. Section 3 accordingly provides a classification of such strategies. Section 4 reviews the basic characteristics of the hedge fund industry, and includes a synopsis of the different institutional relationships involved in hedge fund operations. Quantitative estimates of the recent expansion in hedge funds are provided in Section 5, along with a number of factors that could explain this evolution. Section 6 assesses the impact of hedge funds on financial stability. Section 7 addresses the supervisory concerns related to hedge fund activity and the various initiatives taken so far to address these concerns. Finally, Section 8 concludes by summarising the main issues and provides an outlook for the future.

\section{THE CONCEPT OF HEDGE FUNDS}

Strictly speaking, the term "hedge fund" is not a correct definition of the institutions under consideration. The term has historical significance, as in the beginning of the second half of the last century the first institutions of this kind were engaged in buying and shortselling equities with the aim of eliminating (hedging) the risk of market-wide fluctuations. However, the possibility of using short-selling and other types of hedging is not unique to hedge funds. Moreover, over time hedge funds have started to use a wide variety of other investment strategies that do not necessarily involve hedging.

There is no legal or even generally accepted definition of a hedge fund, although the US President's Working Group on Financial Markets (1999) characterised such entities as "any pooled investment vehicle that 


\begin{tabular}{|c|c|}
\hline Return objective & $\begin{array}{l}\text { Positive absolute returns under all market conditions, without regard to a particular benchmark. } \\
\text { Usually managers also commit their own money; therefore, the preservation of capital is very } \\
\text { important. }\end{array}$ \\
\hline Investment strategies & $\begin{array}{l}\text { Position-taking in a wide range of markets.Free to choose various investment techniques, } \\
\text { including short-selling, leverage and derivatives. }\end{array}$ \\
\hline Incentive structure & $\begin{array}{l}\text { Typically } 1-2 \% \text { management fee and } 15-25 \% \text { performance fee. } \\
\text { Quite often high watermarks apply (i.e. performance fees are paid only if cumulative performance } \\
\text { recovers any past shortfalls) and/or a certain hurdle rate must be exceeded before managers may } \\
\text { receive any incentive allocation. }\end{array}$ \\
\hline Subscription/Withdrawal & $\begin{array}{l}\text { Predefined schedule with quarterly or monthly subscription and redemption. } \\
\text { Lock-up periods for up to one year until first redemption. Some hedge funds retain the right to } \\
\text { suspend redemptions under exceptional circumstances. }\end{array}$ \\
\hline Domicile & $\begin{array}{l}\text { Offshore financial centres with low tax and regulatory regimes, and some other onshore financial } \\
\text { centres. }\end{array}$ \\
\hline Legal structure & $\begin{array}{l}\text { Private investment partnership that provides pass-through tax treatment or offshore investment } \\
\text { corporation. Master-feeder structure may be used for investors with different tax status, where } \\
\text { investors choose appropriate onshore or offshore feeder funds pooled into a master fund. }\end{array}$ \\
\hline Managers & $\begin{array}{l}\text { May or may not be registered or regulated by financial supervisors. Managers serve as general } \\
\text { partners in private partnership agreements. }\end{array}$ \\
\hline Investor base & $\begin{array}{l}\text { High net worth individuals and institutional investors. High minimum investment levels. } \\
\text { Not widely available to the public. Securities issued take the form of private placements. }\end{array}$ \\
\hline Regulation & $\begin{array}{l}\text { Generally minimal or no regulatory oversight due to their offshore residence or "light touch" } \\
\text { approach by onshore regulators; exempt from many investor protection and disclosure } \\
\text { requirements. }\end{array}$ \\
\hline Disclosure & Voluntary or very limited disclosure requirements in comparison with registered investment funds. \\
\hline
\end{tabular}

is privately organised, administered by professional investment managers, and not widely available to the public". ${ }^{1}$ While this definition distinguishes hedge funds from public investment companies, it does not capture many of the distinctive features of hedge funds and is so broad that it includes many other alternative investment vehicles, such as venture capital firms, private equity funds, real estate funds and commodity pools. In contrast to other pooled investment vehicles, hedge funds make extensive use of shortselling, leverage ${ }^{2}$ and derivatives. Nevertheless, it would be inaccurate to assign these attributes exclusively to hedge funds, as other financial companies, including banks and other registered and unregistered investment companies, also engage in such operations. The key difference is that hedge funds do not have any restrictions on the type of instruments or strategies they can use owing to their unregulated or lightly regulated nature. A summary of some key hedge fund characteristics is presented in Table 1, which demonstrates that hedge funds represent a flexible business model and investment process rather than an alternative asset class.

In addition to single hedge funds, there are funds of hedge funds (FOHFs), i.e. funds that invest in a number of other hedge funds. In this way diversification and selection services are provided to investors that are not able to perform adequate due diligence, lack the required expertise or do not meet high minimum investment requirements. FOHFs usually charge less than single hedge funds ${ }^{3}$ and often offer monthly or quarterly redemption to

1 For more definitions, see Vaughan (2003) (www.sec.gov/ spotlight/hedgefunds/hedge-vaughn.htm)

2 In this paper, the term "leverage" refers to both economic (debt) and financial (instrument) leverage. The former is associated with increased assets under management, whereas the latter refers to making investments on margin, where the cost of investment is less than the exposure it generates (e.g. through financial derivatives).

3 Performance and management fees range between 5-15\% and $0.5-1.5 \%$ respectively. However, because of their structure, they do involve different levels of costs, so that the final cost for the investor can end up being high. 
suit institutional and retail investors. Moreover, for the even more risk-averse investor, there are also so-called F3 hedge funds or funds of FOHFs, which represent the third layer on top of single hedge funds (F1) and FOHFs (F2). To be commercially viable, F3 funds have to negotiate substantial fee rebates from underlying FOHFs.

Noting the inaccurate nature of the expression "hedge fund", the European Parliament instead decided to use the term "Sophisticated Alternative Investment Vehicles" (SAIVs), which would also encompass other alternative investment funds that differ from conventional UCITS (Undertakings for Collective Investments in Transferable Securities). ${ }^{4} \mathrm{~A}$ variety of similar terms have elsewhere been used by other institutions. The Basel Committee on Banking Supervision (BCBS) opted to employ the term "highly leveraged institutions" (HLIs), a label covering hedge funds as well as other institutions that are subject to very little or no direct regulatory oversight, have very limited disclosure requirements, and often take on significant leverage. ${ }^{5}$ The Multidisciplinary Working Group on Enhanced Disclosure (MWGED) preferred to use the term "leveraged investment funds". ${ }^{6}$ Interestingly, the United Kingdom's Financial Services Authority (FSA) declined to define the term because of the absence of identifiable commonality; more recently it has indicated for supervisory monitoring purposes its preference to focus on the investment techniques of hedge funds rather than on issues of legal structure. ${ }^{7}$

For the purpose of this paper, the market practice of using the term "hedge fund" will be followed. This term denotes a fund whose managers receive performance-related fees and can freely use various active investment strategies to achieve positive absolute returns, involving any combination of leverage, derivatives, long and short positions in securities or any other assets in a wide range of markets. This working definition stresses the most important features of hedge funds that are likely to endure, given that all other second-tier characteristics, including regulation, registration, investor base and disclosure, will probably evolve. However, this definition does not completely separate hedge funds from private equity or venture capital funds. As a rule, the latter vehicles do not pursue active strategies that extensively employ leverage, short-selling or derivatives, and usually have much longer lock-up periods.

\section{TYPOLOGY OF HEDGE FUNDS}

As noted earlier, the first hedge funds were predominantly engaged in market neutral or "hedged" trading, trying to insulate their positions against market-wide gyrations. This is no longer the case as hedge funds now also pursue directional strategies. Since hedge funds do not have any restrictions on the type of instruments they can use or on how to conduct operations, they are usually classified by their investment style. This criterion is more important for a hedge fund's risk-return profile than its asset class selection or sector/ geographic orientation.

To simplify the analysis, it is useful to group strategies into four major sets: directional, market neutral, event-driven and FOHFs. Directional hedge funds generally try to anticipate market movements and offer high returns commensurate with the high risks and leverage involved. Macro hedge funds are the most prominent example of this investment style. Such funds follow a "top-down" approach, and try to profit from major economic trends or events. Emerging markets and other directional hedge funds with a regional focus, by contrast, favour a "bottomup" approach, i.e. they tend to be asset pickers in certain markets and look for inefficiencies in developing markets.

\footnotetext{
4 European Parliament (2003 and 2004).

Basel Committee on Banking Supervision (1999a)

6 Multidisciplinary Working Group on Enhanced Disclosure (2001).

7 UK's Financial Supervisory Authority (2002 and 2005b).
} 
In contrast to directional funds, market neutral hedge funds (also referred to as arbitrage or relative value funds) search for arbitrage or relative value opportunities to exploit various price discrepancies, and try to avoid exposure to market-wide movements. Here, the meaning of arbitrage is somewhat looser and includes trades that entail some risk of loss or uncertainty about total profits. Such strategies are attractive due to their lower volatility, but they require medium to high leverage in order to benefit from small pricing distortions, particularly in fixed income markets.

Event driven strategies lie somewhere in the middle of the volatility spectrum, with corresponding medium volatility and low to medium leverage. Profit opportunities arise from special occasions in a company's life, such as mergers and acquisitions, reorganisations or bankruptcies. Merger arbitrage typically involves buying the shares of a target company and selling the shares of the acquiring company. Hedge funds investing in distressed securities try to exploit the fact that it is difficult to value such securities, and that many institutional investors are prohibited from investing in them.

Finally, FOHFs should have lower volatility and attractive risk-adjusted returns due to diversification benefits.

The detailed version of the classification used in the TASS database, on which the analysis in this paper is to a large extent based, is provided in Table 2. Other private vendors might use slightly different categories, but such differences are unlikely to be very substantial, as the major strategies are grouped in a broadly similar way.

Investors can access hedge funds in a number of ways, and this diversity can serve as an additional classification criterion. Private placements of limited participation interests in private partnerships or offshore investment fund shares are the most common ways to make direct capital injections. In some cases (for example, in Ireland or Luxembourg), shares of

\section{Table 2 Hedge fund category definitions

\begin{tabular}{|c|c|c|}
\hline Group & Strategy & Description \\
\hline \multirow[t]{4}{*}{ Directional } & Long/Short Equity Hedge & $\begin{array}{l}\text { This directional strategy involves equity-oriented investing on both the long and short } \\
\text { sides of the market. The objective is not to be market neutral. Managers have the } \\
\text { ability to shift from value to growth, from small to medium to large capitalisation } \\
\text { stocks, and from a net long position to a net short position. Managers may use futures } \\
\text { and options to hedge. The focus may be regional, such as long/short US or European } \\
\text { equity, or sector-specific, such as long and short technology or healthcare stocks. } \\
\text { Long/short equity funds tend to build and hold portfolios that are substantially more } \\
\text { concentrated than those of traditional stock funds. }\end{array}$ \\
\hline & Dedicated Short Bias & $\begin{array}{l}\text { Dedicated short-sellers were once a robust category of hedge funds before the long } \\
\text { bull market of the late 1990s rendered the strategy difficult to implement. A new } \\
\text { category, "short biased", has since emerged. The strategy is to maintain net short as } \\
\text { opposed to pure short exposure. Short-biased managers take short positions in mostly } \\
\text { equities and derivatives. The short bias of a manager's portfolio must be constantly } \\
\text { greater than zero to be classified in this category. }\end{array}$ \\
\hline & Global Macro & $\begin{array}{l}\text { Global macro managers carry long and short positions in any of the world's major } \\
\text { capital or derivative markets. These positions reflect their views on overall market } \\
\text { direction as influenced by major economic trends and/or events. The portfolios of } \\
\text { these funds can include stocks, bonds, currencies and commodities in the form of cash } \\
\text { or derivatives instruments. Most funds invest globally in both developed and } \\
\text { emerging markets. }\end{array}$ \\
\hline & Emerging Markets & $\begin{array}{l}\text { This strategy involves equity or fixed income investing in emerging markets around } \\
\text { the world. Because many emerging markets do not allow short-selling, nor offer } \\
\text { viable futures or other derivative products with which to hedge, emerging market } \\
\text { investing often employs a long-only strategy. }\end{array}$ \\
\hline
\end{tabular}




\begin{tabular}{|c|c|c|}
\hline Group & Strategy & Description \\
\hline Directional & Managed Futures & $\begin{array}{l}\text { This strategy invests in listed financial and commodity futures markets and currency } \\
\text { markets around the world. The managers are usually referred to as Commodity } \\
\text { Trading Advisors, or CTAs. Trading disciplines are generally systematic or } \\
\text { discretionary. Systematic traders tend to use price and market-specific information } \\
\text { (often technical) to make trading decisions, while discretionary managers use a } \\
\text { judgemental approach. }\end{array}$ \\
\hline \multirow[t]{4}{*}{ Event Driven } & & $\begin{array}{l}\text { These strategies are defined as special situations investing, designed to capture price } \\
\text { movements generated by a significant pending corporate event such as a merger, } \\
\text { corporate restructuring, liquidation, bankruptcy or reorganisation. }\end{array}$ \\
\hline & Risk (Merger) Arbitrage & $\begin{array}{l}\text { Specialists invest simultaneously long and short in the companies involved in a } \\
\text { merger or acquisition. Risk arbitrageurs are typically long in the stock of the company } \\
\text { being acquired and short in the stock of the acquirer. By shorting the stock of the } \\
\text { acquirer, the manager hedges out market risk, and isolates his/her exposure to the } \\
\text { outcome of the announced deal. The principal risk is deal risk, should the deal fail to } \\
\text { close. Risk arbitrageurs also often invest in equity restructurings such as spin-offs or } \\
\text { "stub trades" that involve the securities of a parent and its subsidiary companies. }\end{array}$ \\
\hline & $\begin{array}{l}\text { Distressed/ } \\
\text { High Yield Securities }\end{array}$ & $\begin{array}{l}\text { Fund managers invest in the debt, equity or trade claims of companies in financial } \\
\text { distress or already in default. The securities of companies in distressed or defaulted } \\
\text { situations typically trade at substantial discounts to par value due to difficulties in } \\
\text { analysing a proper value for such securities, lack of street coverage, or simply an } \\
\text { inability on behalf of traditional investors to value accurately such claims or direct } \\
\text { their legal interests during restructuring proceedings. Various strategies have been } \\
\text { developed by which investors may take hedged or outright short positions in such } \\
\text { claims, although this asset class is in general a long-only strategy. Managers may also } \\
\text { take arbitrage positions within a company's capital structure, typically by purchasing } \\
\text { a senior debt tier and short-selling common stock, in the hope of realising returns from } \\
\text { shifts in the spread between the two tiers. }\end{array}$ \\
\hline & Regulation D, or Reg. D & $\begin{array}{l}\text { This sub-set refers to investments in micro and small capitalisation public companies } \\
\text { that are raising money in private capital markets. Investments usually take the form of } \\
\text { a convertible security with an exercise price that floats or is subject to a look-back } \\
\text { provision that insulates the investor from a decline in the price of the underlying } \\
\text { stock. }\end{array}$ \\
\hline
\end{tabular}

Market Neutral Fixed Income Arbitrage The fixed income arbitrageur aims to profit from price anomalies between related interest rate securities. Most managers trade globally with a goal of generating steady returns with low volatility. This category includes interest rate swap arbitrage, US and non-US government bond arbitrage, forward yield curve arbitrage, and mortgagebacked securities arbitrage. The mortgage-backed market is primarily US-based, over-the-counter (OTC) and is particularly complex.

Convertible Arbitrage This strategy is identified by hedged investing in the convertible securities of a company. A typical investment is long in the convertible bond and short in the common stock of the same company. Positions are designed to generate profits from the fixed income security as well as the short sale of stock, while protecting principal from market moves.

Equity Market Neutral This investment strategy is designed to exploit equity market inefficiencies and usually involves having simultaneously long and short matched equity portfolios of the same size within a country. Market neutral portfolios are designed to be either beta or currency neutral, or both. Well-designed portfolios typically control for industry, sector, market capitalisation, and other exposures. Leverage is often applied to enhance returns.

Multi-Strategy

Multi-Strategy funds are characterised by their ability to allocate capital dynamically among strategies that fall within several traditional hedge fund disciplines. The use of many strategies, and the ability to reallocate capital between them in response to market opportunities, means that such funds are not easily assigned to any traditional category. The Multi-Strategy category also includes funds that employ unique strategies which do not fall under any of the other descriptions. which will be allocated cash to trade on behalf of the fund.

Source: CSFB/Tremont Index (see www.hedgeindex.com) 
hedge funds are listed on the stock exchange. Rising demand from retail investors and remaining regulatory obstacles for direct investments have led to the emergence of indirect investment channels, such as FOHFs or various performance-linked instruments, including unit-linked insurance policies and structured notes (so-called wrappers).

\section{CHARACTERISTICS OF THE HEDGE FUND INDUSTRY}

Any information on the activities of hedge funds is subject to shortcomings, as many hedge funds are domiciled offshore, face relatively few information and disclosure requirements, and provide information only on a voluntary basis. Nearly every private database is imperfect, with different and usually overlapping samples and biases in the data (see Box 1).

In the following, the term "EU hedge funds" refers to funds based (domiciled) in the EU and/ or with managers residing in the EU, which may not necessarily invest exclusively in the EU markets. ${ }^{8}$ Sometimes the term "European hedge funds" may be used by data providers to identify hedge funds that target exclusively European markets. This difference in meaning should be kept in mind when analysing the various data provided in the text.
From a financial stability perspective, both views are important, because one relates to financial institutions, i.e. the asset management industry operating in Europe, and the second one to market impact. The first approach is more common in the case of banks and other financial institutions, and is moreover probably more stable compared to the second one, since hedge funds may change their geographic orientation swiftly, which is less the case for the managers' or fund's location. Managers may also exhibit a domestic bias to some extent.

\section{I LOCATION OF HEDGE FUNDS AND THEIR MANAGERS}

Innovative hedge fund investment strategies require complete freedom and discretion over their implementation. Managers therefore look for minimum regulatory intervention and favourable tax treatment. Offshore tax havens are ideal domiciles ${ }^{9}$ for this purpose, because they offer a low level of regulation and external control, and it is relatively easy to set up and operate a hedge fund there. The Cayman

8 This definition excludes only hedge funds that are managed from outside the EU and not domiciled in the EU. In this way, the definition also captures funds that are domiciled in the EU but managed from outside the EU, and which might therefore be labelled as non-European funds. For more details, see Table 5 .

9 The domicile is the place where the legal entity of the fund is located.

\section{Box I}

\section{INFORMATION IN HEDGE FUND DATABASES}

There are three major providers of hedge fund databases commonly used by public bodies: the Trading Advisors Selection System (TASS), the Centre for International Securities and Derivatives Markets (CISDM) (former MAR/Hedge) and Hedge Fund Research (HFR). The different databases cover only part of the global hedge fund industry and to some extent overlap, as some hedge funds report to more than one data provider. Certain databases may have strong regional biases. For example, Eurekahedge focuses primarily on Asian hedge funds. Based on the latest study of hedge fund databases by Strategic Financial Solutions, the largest and the five largest databases would respectively account for $44 \%$ and $84 \%$ of around 8,100 hedge funds identified in 12 of the best-known databases. ${ }^{1}$ Moreover, given the fact that

1 Strategic Financial Solutions (2004). 
some of the largest hedge fund families do not report to any database, any individual database would, at best, cover only $25-30 \%$ of funds. It would probably be possible to combine information from several databases, but this would most likely prove very laborious for the purpose of a deeper analysis owing to the substantial differences between databases.

Typically, data vendors collect monthly performance data and rely either upon entries by the hedge fund manager or analyst. The submission of data can lag by several months, and accuracy is another concern. Time series data include capital under management and returns, while qualitative information mostly relates to the hedge fund's strategy, geographic focus, types of instruments used, leverage, fees, lock-ups, etc.

The data in such databases typically suffer from a number of biases: ${ }^{2}$

Survivorship bias - this is the statistical bias in performance aggregates due to the inclusion of only live funds and the exclusion of liquidated, no longer operating, or non-reporting funds. Reporting can stop not only when a fund falters because of poor returns or excess volatility, but also because it reaches capacity limits or enjoys good returns and becomes closed to new investors. According to some estimates, this bias can increase aggregate hedge fund returns by an additional $2-3 \%$. In this paper, the analysis is based on the combined version of the TASS database, including both the "Live" and "Graveyard" modules in order to minimise survivorship effects and to produce historical aggregate data covering both active and inactive hedge funds.

(Self) selection bias - each database represents only a sample of the whole hedge fund universe. Funds that do not report due to superior returns offset to some extent the returns of those that do not report due to poor performance, which can render the bias less important. Hedge funds join public databases largely for marketing purposes in order to attract additional funds for investment; only $9 \%$ of active hedge funds in the TASS database indicate that they are closed to new investment. This share has been gradually declining since 1994, when it was $19 \%$.

Instant history or backfill bias occurs when a hedge fund is attached to the database and when a part or the entire historical performance, which is usually quite positive, is added to the database. This may contribute an additional $1-3 \%$ to the recalculated aggregate returns.

Liquidation bias arises because disappearing funds may not report final periods leading up to and including their liquidation.

Many vendors publicly provide only a subset of hedge funds tracked internally. As a result, for example, the public version of the TASS database represents only around four-fifths of funds and more than half of capital under management of all hedge funds available internally to Tremont Capital Management Ltd. (TCM), the manager of the database. The larger internal version is used for proprietary asset management business, consulting and the calculation of CSFB/Tremont hedge fund indices. Certain aggregate information based on the internal database is regularly published by TASS Research, the suite of hedge fund research products owned by TCM. The fact that hedge fund managers not only stop reporting, but also instruct to remove all their historical information from the public version of the database renders

2 See, for example, Hedges (2004b), Malkiel et al. (2004). 
aggregate information obtained from the public database unstable. ${ }^{3}$ For this reason, it is important to indicate the version of the public database from which aggregate information was extracted. In this paper, the information was extracted from the TASS database as of 30 June 2005 , except for the analysis in the last part of sub-section 6.2.3, which was based on the 24 March 2005 version of the database.

TASS provides fund managers with online access to the fund information, and they can review and update the data on a daily basis. However, there is no guarantee that the qualitative information represents the latest changes and some information may even refer to the date when the fund was included in the database. For example, it is unclear to which date the information on average and maximum leverage exactly refers. The user should bear this in mind as only performance and capital under management data are reported as time series. In addition, there are no details on how hedge funds calculate leverage, as the guidance provided by the database manager is rather broad (i.e. portfolio to equity). ${ }^{4}$ Due to high demand for the leverage data, TCM plans to introduce more informative time series data on this particular variable.

In the TASS database there is no explicit information on master-feeder structures. Moreover, without a comparison of individual data or additional information it is difficult to distinguish different classes of hedge fund shares from separate hedge fund legal entities. This paper, as most academic studies, therefore treats all entries as individual hedge funds when calculating aggregate numbers of (funds of) hedge funds.

Furthermore, for some dates hedge funds provide only performance figures, and capital under management needs to be estimated using previous capital data and the latest returns. However, even after this estimation, approximately $1-5 \%$ of funds (or sometimes even up to $10 \%$ of funds in the case of latest data) have no capital figures on a particular date. All the information in this paper refers to the narrower data set that includes only funds with reported (estimated) capital under management. In this way, consistency between aggregate data on the number of hedge funds and their total capital under management is ensured.

\footnotetext{
3 When a new hedge fund joins the database, the addition of backfilled data also changes historical aggregate information.

4 Some hedge funds indicate that they use leverage, but state that their average or maximum leverage is zero. To accommodate for this, in the further analysis a special data group has been created and labelled "leverage 0 ".
}

Islands, the British Virgin Islands, Bermuda and the Bahamas are the most popular offshore financial centres. Compared to the global hedge fund industry (see Chart 1 and Chart 3 ), EU hedge funds tend to be more concentrated offshore and relatively more in the Cayman Islands, Bermuda and the Channel Islands (see Chart 2, Chart 4 and Table 3).

Owing to investor demand and the "light touch" approach adopted by some onshore regulators, new hedge funds have started to consider onshore jurisdictions to govern their operations, including in Luxembourg, Ireland, France, Italy, Germany and some other countries. Based on the TASS sample, the share of hedge funds domiciled in the United States has been declining for the last ten years.

About $70 \%$ of EU hedge funds domiciled in the EU are established in Luxembourg and Ireland, with roughly $40 \%$ and $30 \%$ shares respectively. These two centres are particularly popular among hedge funds managed from the United Kingdom, as hedge funds can be listed on the Irish or Luxembourg stock exchanges and are 


\section{Chart I Number of hedge funds globally by \\ domicile}

( $\%$ of total; end-of-year data)

_ offshore centres

-.... EU

- = - US

- other

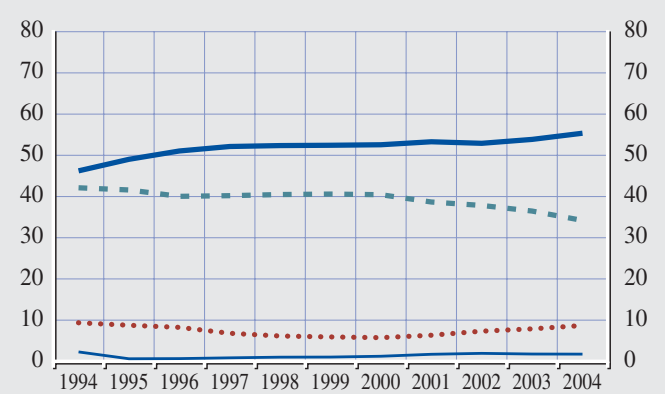

Source: TASS database (30 June 2005 version).

Note: Only funds with reported (estimated) capital under management.

\section{Chart 3 Capital under management of hedge funds globally by domicile}

\section{$(\%$ of total; end-of-year data)}

$$
\begin{array}{ll}
\ldots & \text { offshore centres } \\
\ldots & \text { EU } \\
\ldots- & \text { US }
\end{array}
$$$$
\text { - other }
$$

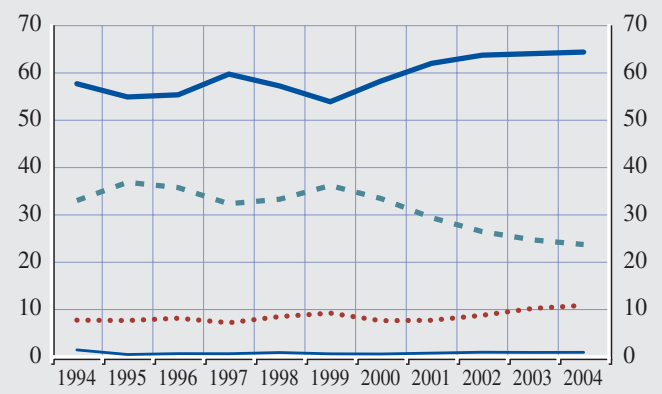

Source: TASS database (30 June 2005 version).

Note: Only funds with reported (estimated) capital under management.

thus attractive to investors that are prohibited from investing outside the EU or in unlisted securities.

In contrast to hedge funds, their managers generally reside in major financial centres and may or may not be registered with local supervisory authorities. Sometimes they are required to register because they also manage

\section{Chart 2 Number of EU hedge funds by} domicile

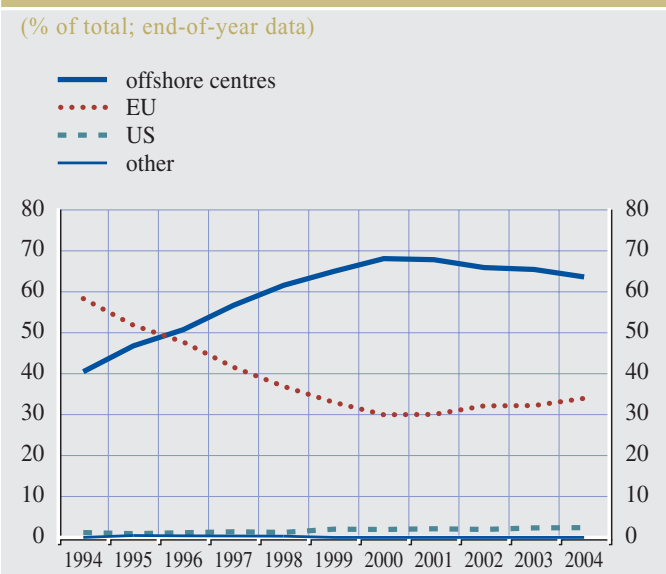

Source: TASS database (30 June 2005 version).

Note: Only funds with reported (estimated) capital under management.

\section{Chart 4 Capital under management of EU hedge funds by domicile}

\section{(\% of total; end-of-year data)}

- offshore centres

-.... EU

$=-$ US

- other

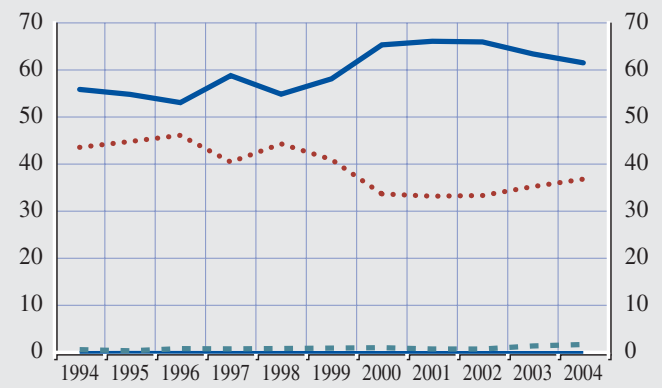

Source: TASS database (30 June 2005 version)

Note: Only funds with reported (estimated) capital under management.

regulated funds, or they do so to enhance their credibility in the eyes of investors. Many of them are former investment bankers or "longonly" investment managers who aim to run their own investment business.

Based on TASS data, the global shares of hedge fund managers located in the EU and offshore centres have been steadily increasing at the 


\section{Chart 5 Number of hedge funds globally by the location of managers}

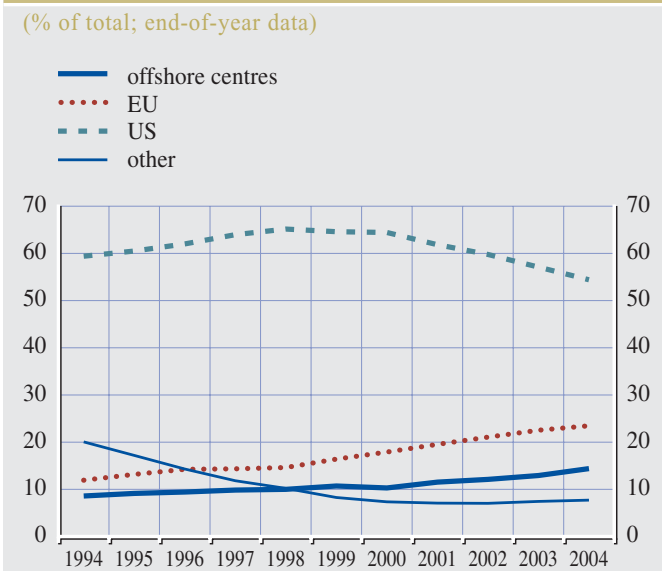

Source: TASS database (30 June 2005 version).

Note: Only funds with reported (estimated) capital under management

\section{Chart 7 Capital of hedge funds globally by} the location of managers

( $\%$ of total; end-of-year data)

offshore centres

…. EU

- = US

other

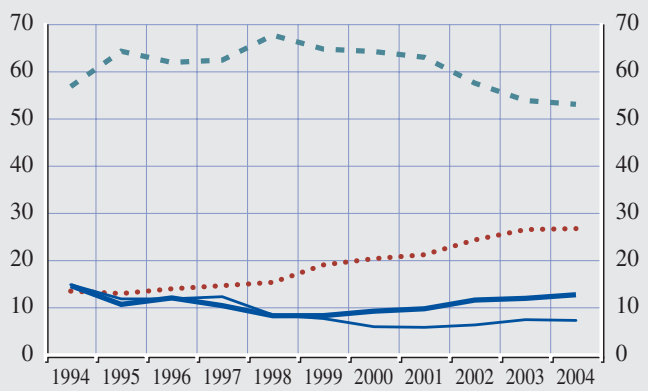

Source: TASS database (30 June 2005 version).

Note: Only funds with reported (estimated) capital under management.

expense of the US managers' share, both in terms of number of funds and capital under management (see Chart 5 to Chart 8). EU hedge funds are almost entirely managed from within the EU. More than $60 \%$ of the EU hedge fund managers are located in London because of its leading role as a financial centre and the presence of a skilled local labour force, as well as competitive

\section{Chart 6 Number of EU hedge funds by the location of managers}

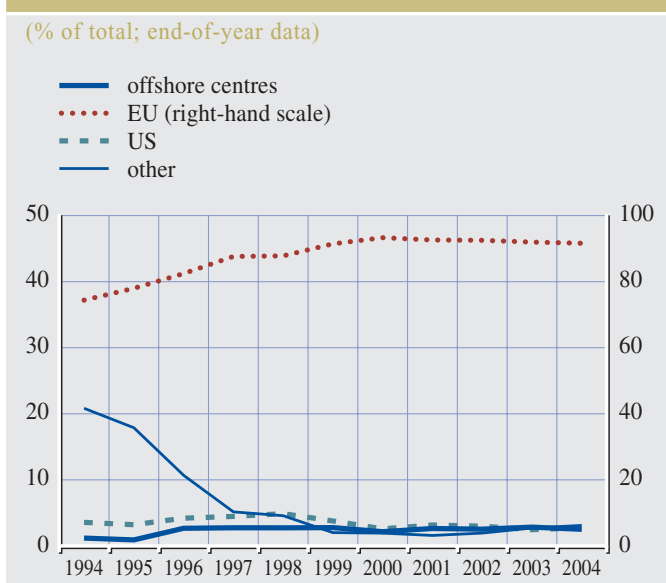

Source: TASS database ( 30 June 2005 version).

Note: Only funds with reported (estimated) capital under management.

\section{Chart 8 Capital of EU hedge funds by the} location of managers

\section{(\% of total; end-of-year data)}

- offshore centre

.... EU (right-hand scale)

$=$ - US

- other

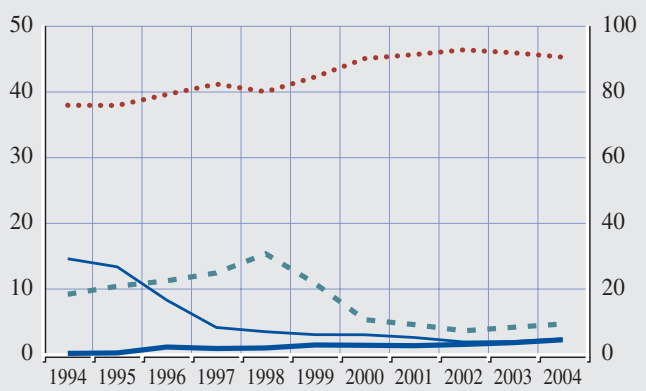

Source: TASS database (30 June 2005 version).

Note: Only funds with reported (estimated) capital under management.

infrastructure and support services (see also Table 4 for data from another source). The second most popular location is Paris with a share of roughly $15 \%$.

Putting together the information on the location of hedge funds and their managers reveals that the EU segment constitutes roughly $25-35 \%$ of the industry, and its market 


\begin{tabular}{|c|c|c|c|c|c|}
\hline \multirow[b]{2}{*}{$\%$ share of offshore hedge funds } & \multirow[t]{2}{*}{$1997^{1)}$} & \multirow[t]{2}{*}{$2002^{2)}$} & \multirow[t]{2}{*}{$2004^{2)}$} & \multicolumn{2}{|c|}{$2004^{3)}$} \\
\hline & & & & $\begin{array}{r}\text { All } \\
\text { funds }\end{array}$ & $\begin{array}{l}\text { EU hedge } \\
\text { funds }\end{array}$ \\
\hline Number of funds & 47 & 40 & 43 & 55 & 64 \\
\hline Capital under management & 69 & 49 & 49 & 64 & 62 \\
\hline \multicolumn{6}{|c|}{$\%$ share of offshore hedge fund capital by domicile } \\
\hline Cayman Islands & 23 & 54 & - & 58 & 60 \\
\hline British Virgin Islands & 21 & 25 & - & 20 & 15 \\
\hline Bermuda & 9 & 10 & - & 12 & 15 \\
\hline Bahamas & 4 & 4 & - & 4 & 1 \\
\hline Netherlands Antilles & 35 & - & - & 2 & 2 \\
\hline Other & 9 & 7 & - & 5 & 8 \\
\hline
\end{tabular}

Sources: 1) Eichengreen et al. (1998) (obtained from MAR/Hedge). 2) International Financial Services, London (2004 and 2005$)$ (obtained from Van Hedge Fund Advisors International Inc. and the US Offshore Funds Directory). 3) TASS database (30 June 2005 version) (only funds with reported/estimated capital under management).

\begin{tabular}{|c|c|c|}
\hline \multicolumn{3}{|c|}{$\begin{array}{l}\text { (estimated number of European-based single manager hedge } \\
\text { funds managed from this country at end-2002) }\end{array}$} \\
\hline Country & $\begin{array}{r}\text { Number of } \\
\text { managers }\end{array}$ & $\begin{array}{l}\% \text { share } \\
\text { of EU15 }\end{array}$ \\
\hline United Kingdom & 394 & 78 \\
\hline France & 39 & 8 \\
\hline Sweden & 18 & 4 \\
\hline Finland & 12 & 2 \\
\hline Ireland & 12 & 2 \\
\hline Germany & 8 & 2 \\
\hline Spain & 6 & 1 \\
\hline Italy & 5 & 1 \\
\hline Netherlands & 5 & 1 \\
\hline Austria & 3 & 1 \\
\hline Denmark & 1 & $\ldots$ \\
\hline Portugal & 1 & $\ldots$ \\
\hline Belgium & $\ldots$ & ... \\
\hline Greece & $\ldots$ & $\ldots$ \\
\hline Luxembourg & $\ldots$ & $\ldots$ \\
\hline Total EU15 & 504 & 100 \\
\hline Switzerland & 36 & 7 \\
\hline United States & 29 & 6 \\
\hline Norway & 4 & 1 \\
\hline Total & 573 & 114 \\
\hline
\end{tabular}

share has been increasing over the last decade. In contrast to the expansion of single hedge funds, EU FOHFs have only recently approached the market share that had prevailed

\section{Chart 9 Market share of EU hedge funds}

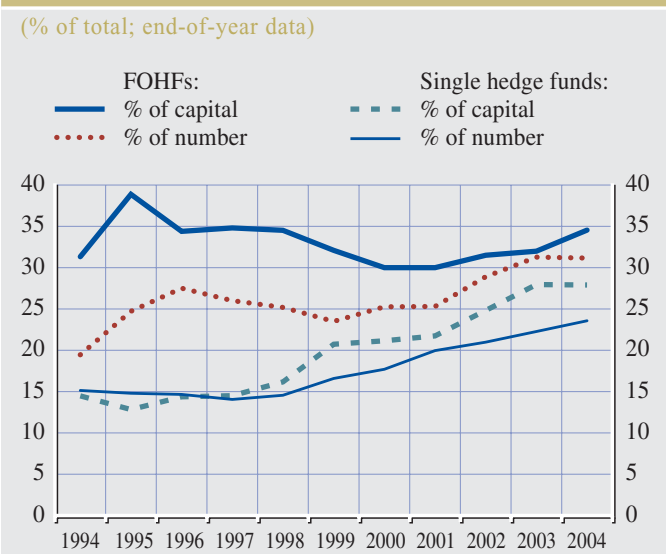

Source: TASS database (30 June 2005 version)

Note: Only funds with reported (estimated) capital under management. in the mid-1990s (see Chart 9). The mapping of the industry by domicile and location of managers is presented in Table 5 . 


\section{Table 5 Mapping of the hedge fund industry by domicile and location of managers}

(end-2004)

\begin{tabular}{|c|c|c|c|c|c|c|c|c|c|c|}
\hline \multirow[b]{3}{*}{$\begin{array}{l}\text { Location of hedge } \\
\text { fund managers }\end{array}$} & \multicolumn{10}{|c|}{ Domictre or heuge tunts } \\
\hline & \multicolumn{5}{|c|}{ Number, $\%$ of total } & \multicolumn{5}{|c|}{ Capital under management, $\%$ of total } \\
\hline & EU & US & $\begin{array}{r}\text { Offshore } \\
\text { centres }\end{array}$ & Other & Total & EU & US & $\begin{array}{r}\text { Offshore } \\
\text { centres }\end{array}$ & Other & Total \\
\hline EU & 7 & 1 & 16 & & 23 & 8 & $\ldots$ & 18 & $\ldots$ & 27 \\
\hline US & 1 & 33 & 21 & $\ldots$ & 54 & 1 & 23 & 29 & $\ldots$ & 53 \\
\hline Offshore centres & 1 & $\ldots$ & 13 & $\ldots$ & 14 & 1 & $\ldots$ & 12 & $\ldots$ & 13 \\
\hline Other & 1 & $\ldots$ & 5 & 2 & 8 & 1 & $\ldots$ & 6 & 1 & 7 \\
\hline Total & 9 & 34 & 55 & 2 & 100 & 11 & 24 & 64 & 1 & 100 \\
\hline
\end{tabular}

Source: TASS database (30 June 2005 version)

Notes: The shaded areas refer to the shares of EU hedge funds. Only funds with reported (estimated) capital under management.

\subsection{INCENTIVE STRUCTURE AND FAILURE RATES}

Incentive schemes used by hedge funds are an important element of their success. Performance fees are typically asymmetric, as they reward positive absolute returns without a corresponding penalty for negative returns. However, in instances where managers commit their own money, the preservation of capital is very important and the motivation to take excessive risks is to some extent curtailed. Unlike hedge fund managers, traditional fund managers may lose flow income in case of poor

\begin{tabular}{|c|c|c|c|c|}
\hline \multirow{2}{*}{$\begin{array}{l}\text { Cumulative } \\
\text { failure } \\
\text { rates, } \%\end{array}$} & \multicolumn{3}{|c|}{$\begin{array}{l}1995-2002^{1)} \\
\text { by capital under management }\end{array}$} & \multirow[b]{2}{*}{$1994-1998^{2)}$} \\
\hline & $\leq \$ 50 \mathrm{~m}$ & $\$ 50-150 \mathrm{~m}$ & $>\$ 150 \mathrm{~m}$ & \\
\hline 1-year & 3.5 & 3.8 & 2.0 & 1.5 \\
\hline 2-year & 8.5 & 10.2 & 2.8 & 4.6 \\
\hline 3-year & 11.8 & 20.4 & 2.9 & 19.6 \\
\hline 4-year & 18.9 & 34.5 & 3.6 & 33.0 \\
\hline 5-year & 23.7 & 38.7 & 3.6 & 42.3 \\
\hline 6-year & 27.2 & 53.0 & 3.6 & - \\
\hline 7-year & 32.0 & 66.0 & 3.6 & - \\
\hline
\end{tabular}

Sources: 1) Hedges (2004a). 2) US President's Working Group on Financial Markets (1999), p. A-5.

Note: For the methodologies applied, please consult the indicated sources. fund performance, but they do not suffer an immediate loss to their existing wealth. It is not unusual for a hedge fund manager to receive his/her first performance compensation only after one or two years due to high watermarks ${ }^{10}$ and hurdle rates. ${ }^{11}$

10 A watermark is a fund valuation below which performance fees are not paid. With a high watermark, performance (incentive) fees are paid only if cumulative performance recovers any past shortfalls. Therefore, a hedge fund manager who loses in the first year and then merely regains that loss in the second year will not receive an incentive payment for the second year's gain.

11 The hurdle rate is the minimum return that must be generated before fund managers may receive any performance allocation.

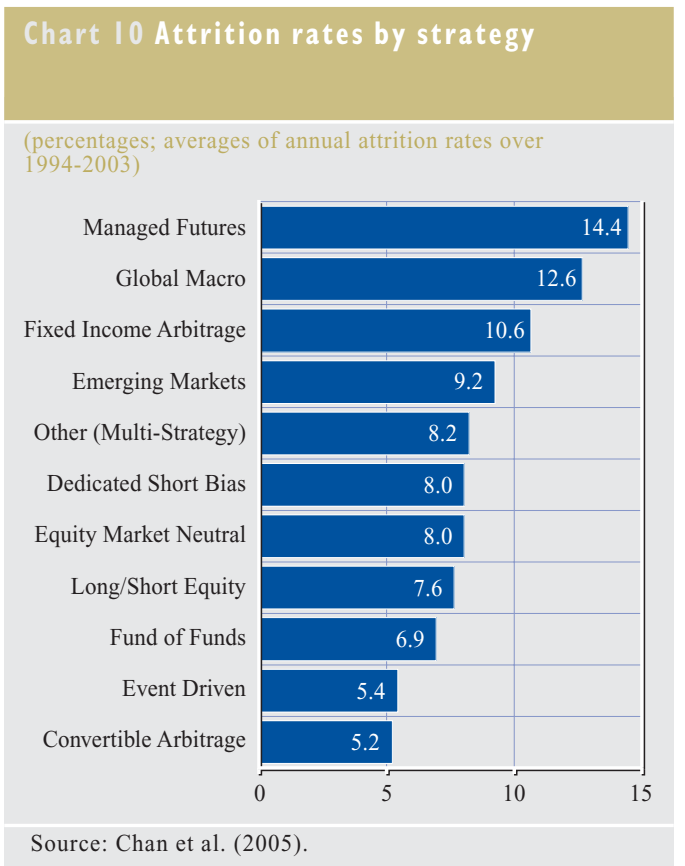


Hedge fund survival rates are rather low, and failure rates for the sample of hedge funds in the first year of the period used for the estimation typically range between $2 \%$ and $4 \%$ (see Table 6). According to another study, the average annual attrition rate in the TASS database over the sample period 1994-2003 was $8.8 \%,{ }^{12}$ although other market estimates put the figure at about 5\%. ${ }^{13}$ Not surprisingly, macro, managed futures and other hedge funds with volatile returns show the highest attrition rates (and the lowest survival rates ${ }^{14}$ ) (see Chart 10). Frequently hedge funds also close for reasons unrelated to poor performance, such as mergers, restructurings or the departure of key managers. The incentive structure, in particular the presence of high watermarks, is equally responsible for the high rates of attrition. Indeed, it is not economic for managers to continue operating a fund that has suffered large losses, making the prospect of receiving performance fees in the future very remote.

\subsection{PARTIES INVOLVED}

Hedge fund managers are typically reluctant to undertake administrative duties and prefer to concentrate on their proprietary investment strategies. Support services are therefore often outsourced to administrators, in particular by smaller funds. Administrators handle a variety of tasks, including the setting up of a hedge fund, the valuation and calculation of its net asset value, record-keeping and accounting, legal advice, reporting and the processing of investor transactions. Administrators are usually hired by offshore hedge funds; onshore hedge funds tend to rely on prime brokers for operational support, although this is changing as well. In the TASS database, about $75 \%$ of funds provide information on their administrators.

Prime brokers are banks or securities firms offering brokerage and other professional services to hedge funds and other large institutional clients. Prime brokerage services involve financing, clearing and settlement of

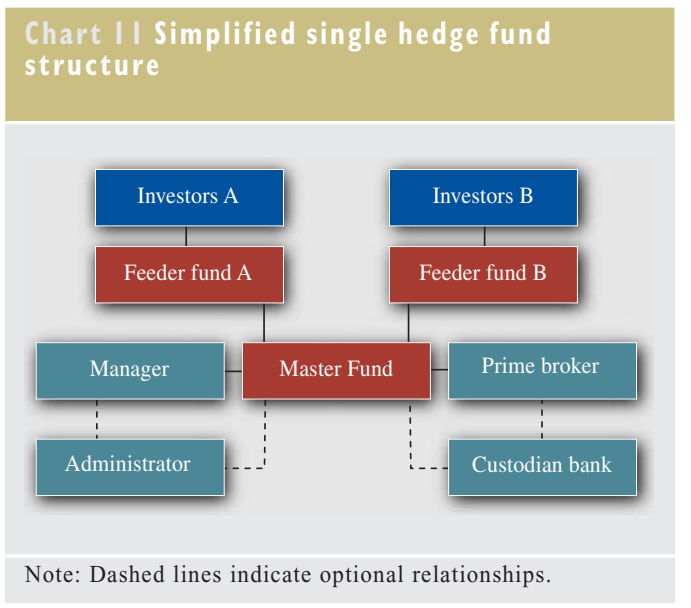

trades, custodial services, risk management and operational support facilities. Clients may also be offered access to research and consulting services. For new hedge funds, capital introduction services, whereby prime brokers introduce managers to potential investors, may be particularly vital. The major share of prime brokers' income comes from trading commissions, collateralised cash lending and stock or bond lending to facilitate short-selling.

The assets of a hedge fund are sometimes deposited with a custodian bank instead of a prime or clearing broker. Compared to the latter, a custodian bank is subject to fiduciary duties and has an obligation to protect the fund's assets and to act in its best interests. This arrangement provides an additional safeguard to hedge fund investors, as the prime broker holds fund assets largely as a principal and as a security against underlying fund positions, i.e. mainly to protect its own interests. ${ }^{15}$ The typical hedge fund structure is depicted in Chart 11, although this is only a simplification of structures that are sometimes very complex. ${ }^{16}$

12 Chan et al. (2005).

13 See, for example, the press release of 3 February 2005 at http://www.hennesseegroup.com

14 US President's Working Group on Financial Markets (1999), p. A-4.

15 Atiyah and Walters (2004).

16 PricewaterhouseCoopers (2004a), p. 10 and p. 61. 
Table 7 How investors typically learn of new managers

$(\%$ of total)

Network (word of mouth)

Prime brokers

From actual managers

Third-party marketers

Large scale conferences

Niche conferences

Newsletters

Consultants

Other

Source: Deutsche Bank (2004).

\subsection{INVESTORS}

Hedge funds generally secure investors through word of mouth, consultants, registered representatives, brokers or investment advisors. According to Deutsche Bank's 2004 Alternative Investment Survey, more than 40\% of investors identify new hedge fund managers by word of mouth and through prime brokers (see Table 7).

For a long time, high net worth individuals were the dominant source of funds for hedge funds (see Chart 12) and this fact,

\section{Chart 12 Hedge fund investors}

HEDGE FUND

INDUSTRY

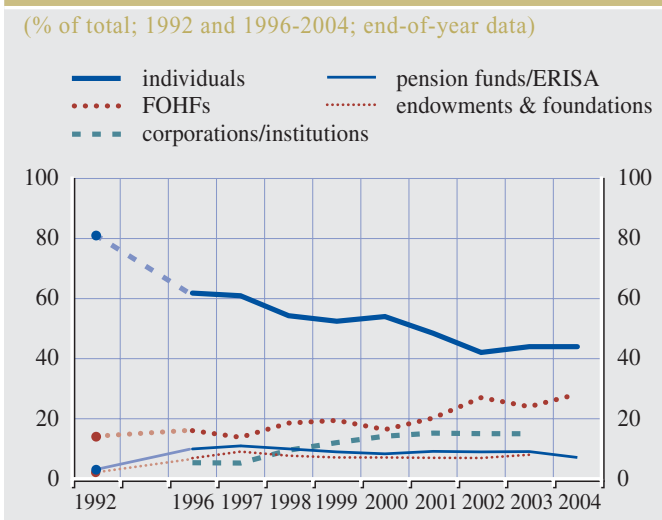

Source: Gradante (2003) and Hennessee Group.

Note: 1992 data from International Financial Services, London (2004) (obtained from Hennessee Group and CQA analysis).

notwithstanding the LTCM debacle, diluted concerns about the systemic importance of hedge funds. However, growing knowledge concerning hedge fund products and their riskadjusted diversification properties has also prompted demand from institutional investors. The low interest rate environment and the associated "hunt for yield" that characterised financial markets from 2003 also contributed to this evolution. ${ }^{17}$ For example, a survey commissioned by Pioneer Investments revealed that nearly $50 \%$ of UK pension

17 European Central Bank (2004 and 2005).

\begin{tabular}{|c|c|}
\hline Liquidity risk & $\begin{array}{l}\text { Limited ability to withdraw money at short notice, given that lengthy lock-up periods or other } \\
\text { redemption constraints are in place. }\end{array}$ \\
\hline Valuation risk & $\begin{array}{l}\text { Although generally valuation of hedge fund assets is outsourced to administrators or prime } \\
\text { brokers, the manager retains the final right to modify asset values and hedge fund performance } \\
\text { may be misrepresented. }\end{array}$ \\
\hline Human risk & $\begin{array}{l}\text { The success of a hedge fund depends on key people managing it; the departure of certain managers } \\
\text { may therefore adversely affect future performance. }\end{array}$ \\
\hline Style drift risk & $\begin{array}{l}\text { The risk that the manager may change or abandon the stated primary strategy or strategies without } \\
\text { informing investors; the future risk-return profile, correlation with other asset classes may no } \\
\text { longer suit the investor portfolio. }\end{array}$ \\
\hline Size risk & $\begin{array}{l}\text { Some strategies may no longer be viable when assets under management exceed a certain } \\
\text { threshold. }\end{array}$ \\
\hline
\end{tabular}




\section{Table 9 Hedge funds by size of fund}

\begin{tabular}{|c|c|c|c|c|c|c|c|c|c|}
\hline \multirow[b]{2}{*}{$2004^{11}$} & \multicolumn{3}{|c|}{ Offshore funds } & \multicolumn{3}{|c|}{ All funds } & \multicolumn{3}{|c|}{ EU funds } \\
\hline & $\leq \$ 100 \mathrm{~m}$ & $\$ 100 \mathrm{~m}-\$ 1 \mathrm{bn}$ & $>\$ 1$ bn & $\leq \$ 100 \mathrm{~m}$ & $\$ 100 \mathrm{~m}-\$ 1 \mathrm{bn}$ & $>\$ 1 b n$ & $\leq \$ 100 \mathrm{~m}$ & $\$ 100 \mathrm{~m}-\$ 1 \mathrm{bn}$ & $>\$ 1 \mathrm{bn}$ \\
\hline$\%$ of number & 63 & 35 & 3 & 67 & 31 & 2 & 59 & 39 & 2 \\
\hline$\%$ of capital & 12 & 65 & 23 & 15 & 66 & 20 & 12 & 69 & 19 \\
\hline average size $\$ \mathrm{~m}$ & 31 & 310 & 1,433 & 31 & 302 & 1,416 & 34 & 293 & 1,334 \\
\hline \multicolumn{10}{|l|}{$2002^{2)}$} \\
\hline$\%$ of number & 64 & 33 & 3 & - & - & - & - & - & - \\
\hline$\%$ of capital & 9 & 48 & 43 & - & - & - & - & - & - \\
\hline average size $\$ \mathrm{~m}$ & 32 & 304 & 2,687 & - & - & - & - & - & - \\
\hline
\end{tabular}

Sources: 1) TASS database (30 June 2005 version) (only funds with reported/estimated capital under management). 2) International Financial Services, London (2004) (obtained from the US Offshore Funds Directory).

managers either invest money in hedge funds or plan to do so. ${ }^{18}$ The appetite to invest in hedge funds is, however, not uniform across institutional investors. Pension funds and endowments are reported as showing significant interest, but this seems to be less the case for insurance companies, at least in Europe. European insurers are said to allocate only $1-2 \%$ of their portfolios to hedge funds, although they are rethinking their strategies and do plan to increase allocations. ${ }^{19}$

Investing in hedge funds carries several forms of risk. Apart from performance risk, hedge fund investors face a variety of other risks, some of which relate to the integrity of managers (see Table 8).

\subsection{FUND SIZE}

Most hedge funds are relatively small: the vast majority has less than USD 100 million of capital under management, while nearly half have even less than USD 25 million (see Table 9 and Table 10, Chart 13 to Chart 16 and Annex A, Tables A1 and A2). EU hedge funds (i.e. funds managed from or based in the EU) do not differ significantly from their peers in this respect, but are generally smaller, particularly when compared with offshore hedge funds. At the end of 2004, there were 65 hedge funds in the TASS database with assets under management exceeding USD 1 billion. Of those 19, or more than one quarter, were EU hedge funds.

There is no conclusive evidence on whether size matters for hedge fund returns, although there are indications that smaller hedge funds seem to outperform larger ones, while midsized funds lag both other groups. This suggests the phenomenon of a "mid-life crisis" for hedge fund managers which is related to the growth of their capital under management. ${ }^{20}$ The link, of course, may vary depending on the hedge fund strategy, and macro hedge funds seem to be an exception.

\footnotetext{
18 Bradbery (2004).

19 Wolcott (2004)
}

20 Hedges (2004a)

\section{Table 10 Hedge fund size}

\begin{tabular}{|c|c|c|c|c|c|}
\hline$\%$ of number & under \$5m & $\$ 5-25 m$ & $\$ 25-100 \mathrm{~m}$ & $\$ 100-500 \mathrm{~m}$ & over $\$ 500 \mathrm{~m}$ \\
\hline 2002 & 16 & 29 & 32 & 19 & 4 \\
\hline 2003 & 10 & 28 & 32 & 24 & 6 \\
\hline
\end{tabular}

Sources: PricewaterhouseCoopers (2004a) and International Financial Services, London (2005) (in both cases obtained from Van Hedge Fund Advisors International Inc.). 


\section{Chart I 3 Number of hedge funds globally by strategy and size}

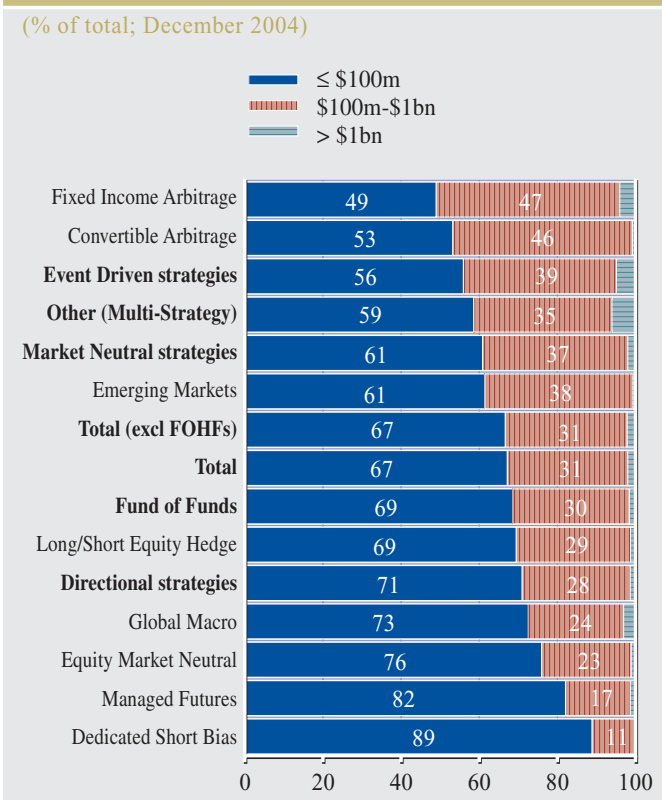

Source: TASS database (30 June 2005 version)

Note: Only funds with reported (estimated) capital under management.

\section{Chart I5 Capital of hedge funds globally by} strategy and size

\begin{tabular}{|c|c|c|c|}
\hline \multicolumn{4}{|c|}{ (\% of total; December 2004) } \\
\hline & 두 & $\begin{array}{l}\leq \$ 100 \mathrm{~m} \\
\$ 100 \mathrm{~m}-\$ 1 \mathrm{bn} \\
>\$ 1 \mathrm{bn}\end{array}$ & \\
\hline Other (Multi-Strategy) & 6 & 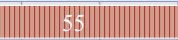 & 39 \\
\hline Global Macro & 14 & 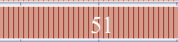 & 34 \\
\hline Event Driven strategies & 10 & |5i9.|| & 31 \\
\hline Fixed Income Arbitrage & 7 & 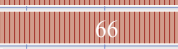 & 27 \\
\hline Total (excl FOHFs) & 14 & |||||| 66|||| & 20 \\
\hline Total & 15 & $\|$ if6 & 20 \\
\hline Managed Futures & 21 & 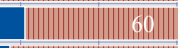 & 19 \\
\hline Fund of Funds & 17 & $\| 6=$ & 18 \\
\hline Market Neutral strategies & 111 & "Inil||| & 18 \\
\hline Equity Market Neutral & 19 & 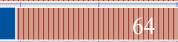 & 17 \\
\hline Directional strategies & 17 & $\|$ & 15 \\
\hline Long/Short Equity Hedge & 17 & $\|$ |69" & 13 \\
\hline Convertible Arbitrage & 12 & $\|$ & \|\|||$\underline{\underline{6}}$ \\
\hline Emerging Markets & 14 & $\|80\|$ & |||| $\mid 5$ \\
\hline Dedicated Short Bias & & 39 & \\
\hline & & & 80 \\
\hline
\end{tabular}

Source: TASS database (30 June 2005 version)

Note: Only funds with reported (estimated) capital under management.

\section{Chart 14 Number of EU hedge funds by strategy and size}

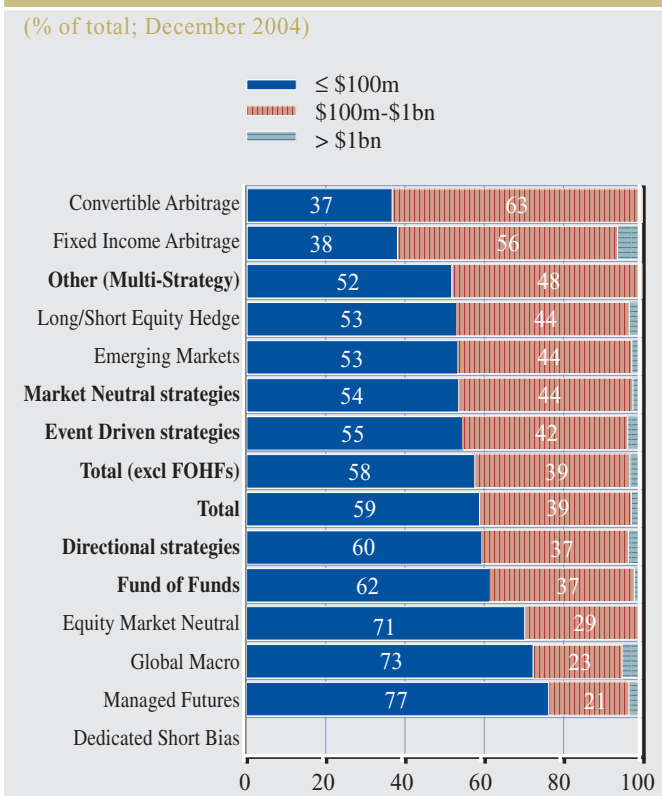

Source: TASS database (30 June 2005 version).

Note: Only funds with reported (estimated) capital under management.

\section{Chart I 6 Capital of EU hedge funds by} strategy and size

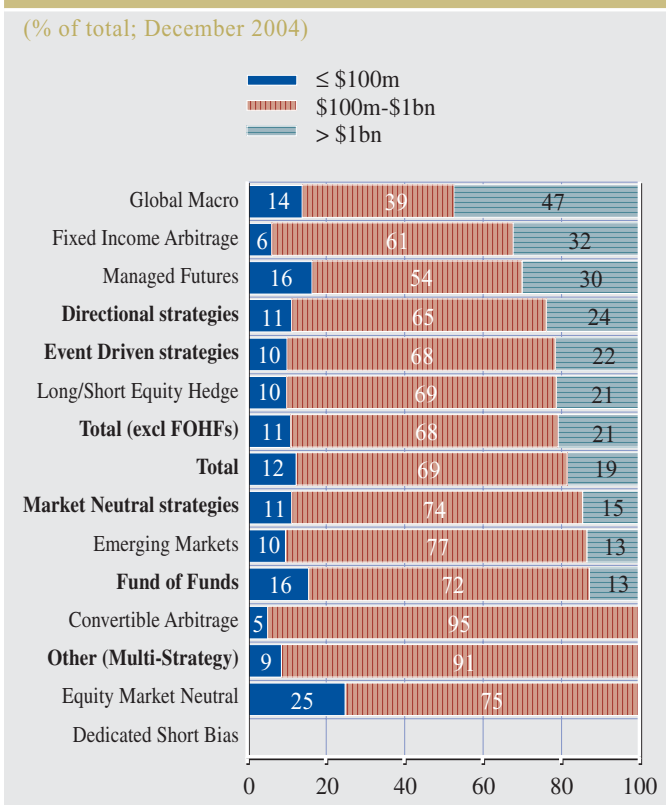

Source: TASS database (30 June 2005 version)

Note: Only funds with reported (estimated) capital under management. 

BUSINESS

In an environment of low interest rates and low returns in financial markets, investors have been searching for alternative investments to improve risk-adjusted returns. In this regard, hedge funds represent a natural candidate. All data sources confirm strong growth in the number of hedge funds and capital under management (see Chart 18 and Annex A, Tables A1-A4). According to TASS Research, inflows into the hedge fund industry in 2004 continued to surpass previous records, reaching USD 123 billion (excluding FOHFs) (see Chart 17). The latest estimates of the total capital under management are over USD 1 trillion, a figure which furthermore does not include managed accounts accepted by hedge fund managers and managed using hedge fundlike strategies (totalling around USD 300 billion at the end of 2004, according to TASS Research).

Between 1993 and 2004, hedge fund capital under management grew at an annualised compound growth rate of $27 \%$. In this period there were only a few quarters with negative inflows, the most notable of which were two consecutive quarters starting at the end of 1998 , just after the near collapse of LTCM. The LTCM episode seriously shook the industry, but proved to be only a temporary setback to an accelerating long-term trend.

In 2004, all strategies recorded positive inflows. Funds with directional strategies preserved their market share of total capital under management, although their share had been on a downward trend from 1994 onwards, which was largely due to a decline of global macro funds (see Chart 19). Since 1995, long/short equity hedge funds have remained the largest single strategy and represented around one-third of the industry at the end of 2004 (see Chart 20). Event driven and market neutral strategies have gained in importance during the last decade, but during the last two years, even these strategies were outpaced by other (mostly multi-strategy) funds.
The last six quarters were also quite successful for event driven funds.

According to International Financial Services, London (IFSL) estimates, at the end of 2004 most capital under management came from the United States (69\%), although Europe (23\%), Asia (5\%) and other regions (3\%) are becoming more important sources of funds. ${ }^{21}$

Investors bring in new funds mainly on the assumption that past returns will continue to be realised (see Chart 21 and Chart 22). However, it is questionable whether hedge funds will be able to maintain their impressive historical track record as the number of new hedge funds increases, potentially leading to an increasing number of managers trying to exploit the same market opportunities, possibly also relying upon similar models.

A pattern of segmentation appears among single hedge funds, some of which prefer to deal only with institutional investors or FOHFs, whereas others have been trying to maintain a more or less balanced investor structure with high net worth individuals still accounting for a significant share of total capital under management. However, according to market participants, institutional investors do not look at small hedge funds or provide seed capital. Many institutional investors have a minimum size of allocation in absolute terms and limit their investments in relation to the total capital under management of a target hedge fund. The current trend is that smaller hedge funds with less than USD 100 million under management usually obtain funds from FOHFs, while the larger ones with USD 1 billion take money directly from institutional investors. ${ }^{22}$

The role of FOHFs has been increasing, and they should provide investors with an additional layer of due diligence and diversification (see Chart 23). However, there

\footnotetext{
21 International Financial Services, London (2005).
}

22 Barclays Capital (2003) and Deutsche Bank (2005). 


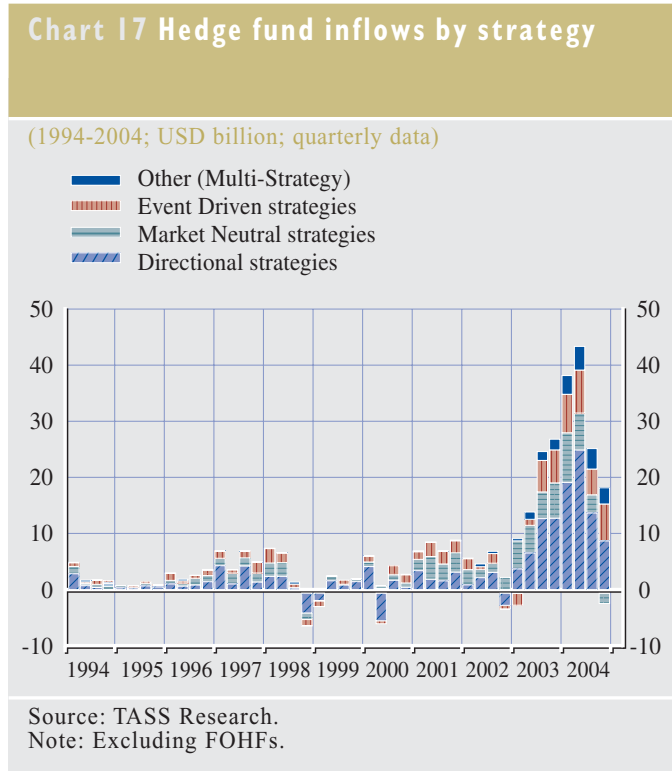

\section{Chart 19 Hedge fund capital structure by strategy}

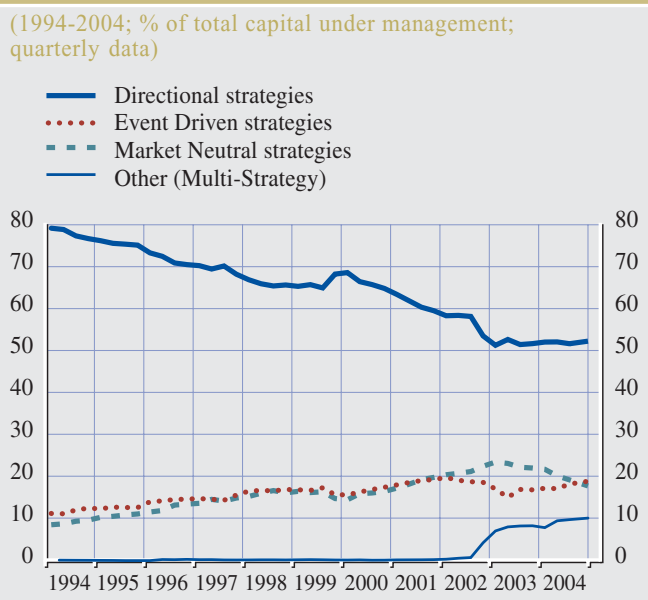

Source: TASS Research.

Note: Excluding FOHFs.

is little evidence as to how effectively they perform this task and how well they are diversified. ${ }^{23}$ In order to guarantee minimum diversification, German FOHFs, for example, can allocate no more than $20 \%$ of their capital under management to a single hedge fund. FOHFs are the main vehicle for the "retailisation" of the hedge fund industry, and in some European countries, only FOHFs are allowed for public offering. There are some concerns that retail investors fail to realise or

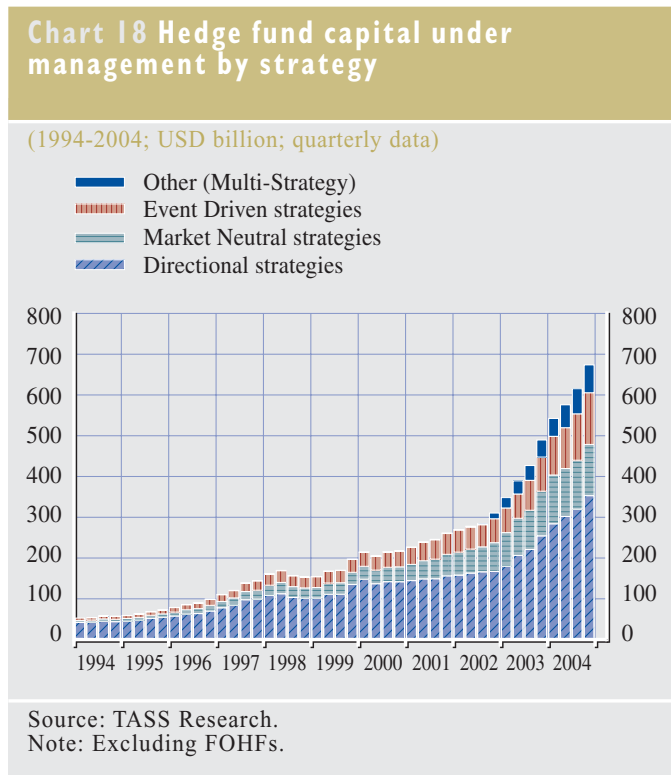

5 RECENT

\section{Chart 20 Hedge fund capital structure by} strategy

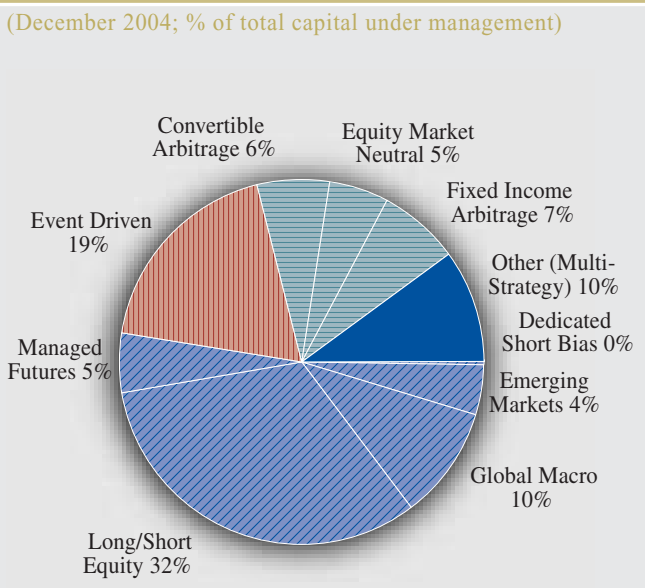

Source: TASS Research.

Note: Excluding FOHFs.

are not informed properly that FOHF fees are levied on top of the fees charged by underlying hedge funds - which can indeed have a significant impact on final FOHF returns.

The hedge fund industry has also become increasingly institutionalised. Banks have been setting up their own hedge funds in order

23 According to Deutsche Bank's 2005 Alternative Investment Survey, $80 \%$ of FOHFs were invested in more than 20 hedge funds, $15 \%$ in $6-20$ and $6 \%$ in less than 6 hedge funds. 


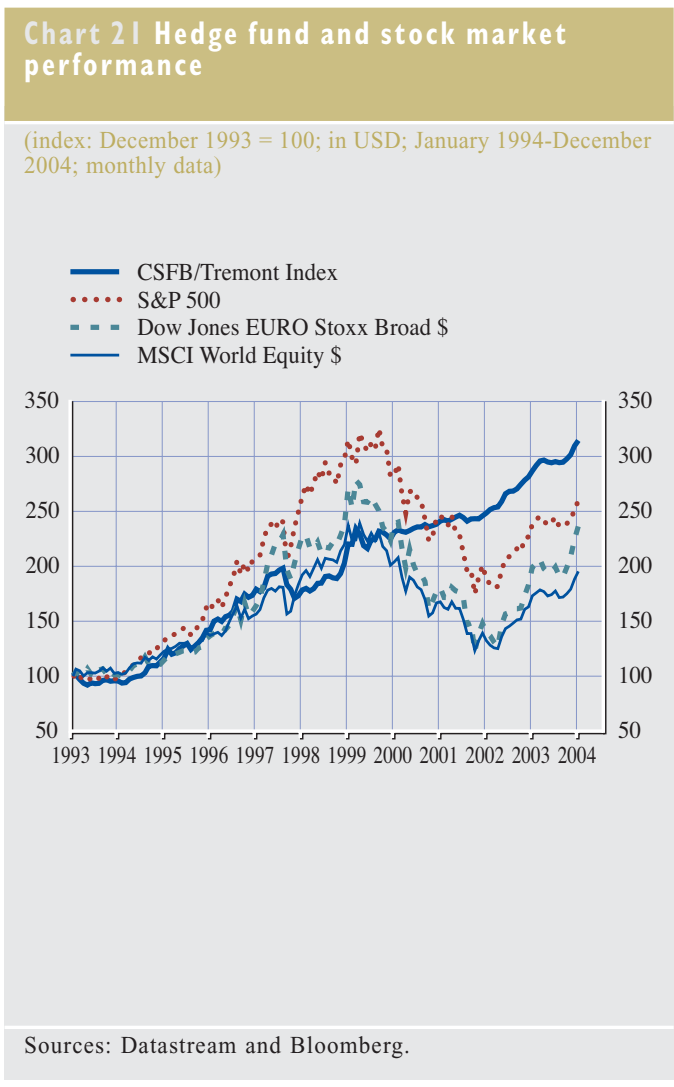

to offer investors the full spectrum of available traditional and alternative investments. They have also been seeking to participate in what might prove to be a structural change in the asset management industry.

The costs of running a hedge fund are increasing, as managers face more complex regulatory, taxation and anti-money laundering issues. The minimum investments with regard to infrastructure and risk management systems are also higher, although the total initial costs are still relatively manageable. Some market participants indicate that it is uneconomic to operate a hedge fund with less than USD 50-100 million under management and a deal involving a $2 \%$ management fee and a $20 \%$ performance fee. ${ }^{24}$ Only larger hedge funds can benefit from economies of scale, so the hedge fund industry will most probably become increasingly concentrated over time. The entrance of banks with their own hedge funds may further contribute to this trend.

\section{Chart 22 Hedge fund, stock and bond markets performance in 2004}
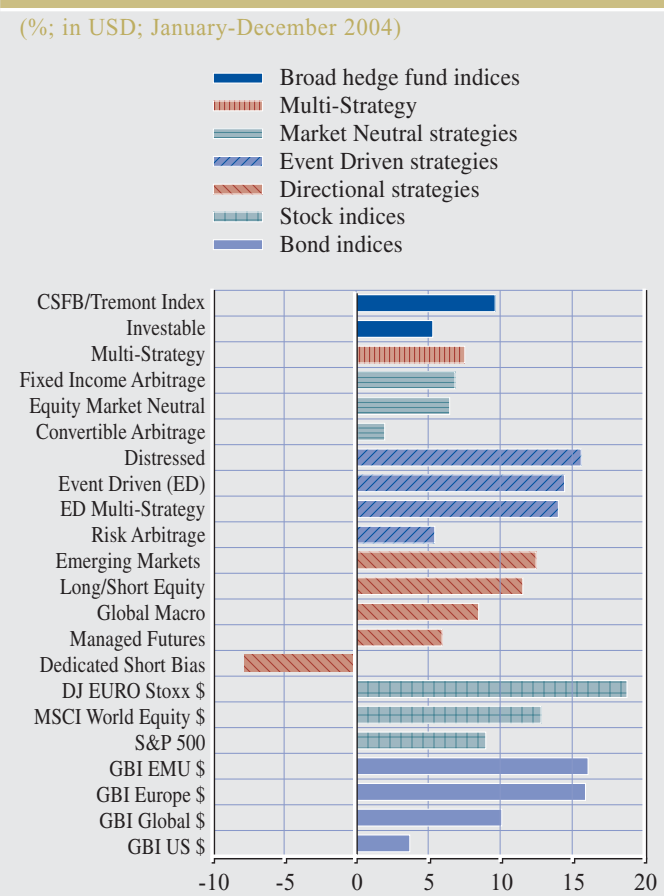

Sources: Datastream and Bloomberg.

Lured by high performance fees, many talented bankers and traditional fund managers are now leaving for hedge funds, which raises the question of whether remaining staff will be able to cope with the new challenges. Investment banks have reacted to this "brain drain" by setting up in-house hedge funds and by offering their staff more attractive compensation schemes. The size of assets managed by traditional financial institutions continues to be higher than those of hedge funds by a very large margin. It is therefore important that this evolution does not hamper the stability and the financial intermediation role of the traditional fund management business.

The recent expansion in hedge funds will certainly affect the global asset management industry, and public authorities will have to

24 Barclays Capital (2003) and Radley \& Associates (2005). 


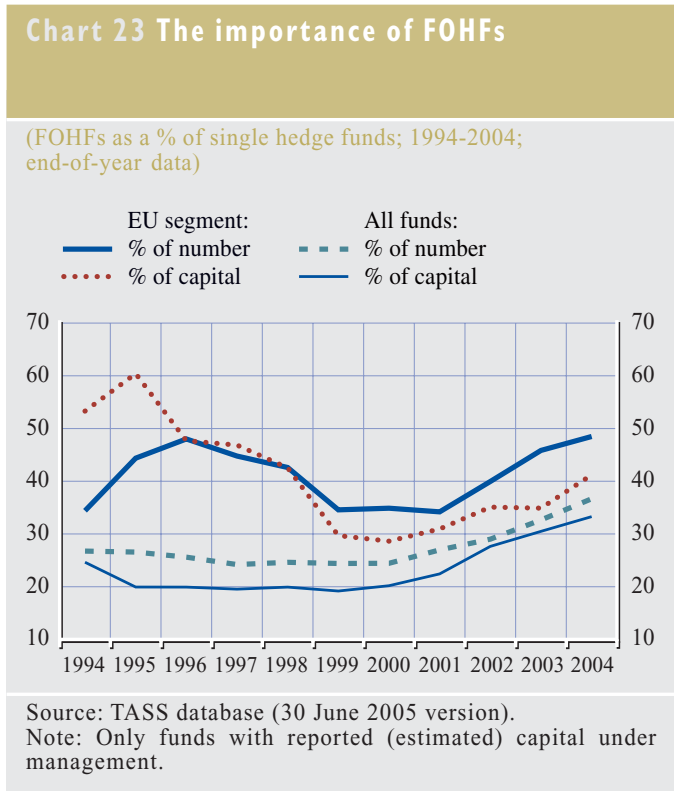

decide on the appropriate regulatory framework that leaves them more or less comfortable with this new business model. It might also be argued that differences between the traditional fund management industry and hedge funds may become increasingly blurred, as conventional funds start using hedge fund investment techniques and hedge funds are forced to lower their fees.

\section{FINANCIAL STABILITY IMPLICATIONS}

\section{I POSSIBLE POSITIVE EFFECTS}

The overall size of hedge funds is still relatively limited, but their active role in markets makes them much more important than their size alone. Every additional market participant provides complementary liquidity to the market. However, the input of hedge funds is very significant, as they often take alternative market views, can leverage their positions and change their portfolio composition much more frequently than traditional funds. They thrive on perceived inefficiencies by arbitraging away price differences for the same risk across markets. In this way, hedge funds contribute to the price discovery process. It might also be argued that, in this way, hedge funds have contributed to the further integration of financial markets.

Hedge funds also tend to be risk-takers in a number of markets. This is especially the case in fledgling and sophisticated markets, where risks are more difficult to quantify and hedge fund managers have a competitive edge because of their superior models. The credit derivatives market is just one example of such a market. According to the British Bankers' Association, hedge funds' share as sellers in the credit derivatives market has surged from $5 \%$ in 2001 to $15 \%$ in 2003 , while their share as buyers rose in the same period from $12 \%$ to $16 \% .{ }^{25}$ According to another survey by Greenwich Associates, hedge funds account for $15-30 \%$ of the trading volume in each of the high yield bond, credit derivatives, collateralised debt obligations (CDO), emerging bond, leveraged loans markets and for more than $80 \%$ of trading in distressed debt. ${ }^{26}$ More regulated financial institutions are usually reluctant to be exposed to such risks and prefer to earn fees or other types of income with lower risks. The presence of hedge funds as active market participants contributes to the development and liquidity of new specialised over-the-counter (OTC) markets, leads to the development of better risk management tools, and enhances the spreading of risks among market participants.

It has been argued that hedge funds' activity may lead to lower market volatility because they are less likely to engage in "momentum trading" (i.e. buying into a rising market and selling into a falling one) and impose longer redemption horizons on their investors. Another element that may support this argument is that they are willing to put their capital at risk in volatile market conditions so that market shocks can be absorbed. Through their ability to engage in short-selling and to

25 British Bankers' Association (2004).

26 Fitch Ratings (2005). 
take contrarian approaches, they may also act as a counterbalance to market herding.

In addition, hedge funds seem to provide attractive diversification benefits (see Table 11). Based on data from the past 11 years, all correlation coefficients between CSFB/Tremont Hedge Fund family indices and major stock market indices were below 0.61 and even negative in the case of dedicated short bias and managed futures strategies.

The case for the inclusion of hedge funds into an investor's portfolio becomes even more compelling when historical risk-adjusted returns are taken into account. With the exception of certain directional strategies, other hedge fund strategies seem to outperform stock and bond markets on a risk-adjusted basis (see Chart 24 and Chart 25). Thus, new combinations in the risk-return space can be achieved with hedge funds, thereby increasing the completeness of financial markets. This should ultimately also result in greater social welfare. However, the evidence that hedge funds outperform the market is not yet conclusive, as there are many reservations with respect to the accuracy of hedge fund indices and the sensitivity of comparisons to the choice of the sample period. Moreover, reported hedge fund returns could be smoother than true economic returns possibly because of greater

\section{Table II Correlation matrix of hedge fund, stock and bond market returns}

\begin{tabular}{|c|c|c|c|c|c|c|c|c|c|c|}
\hline & & & \multirow[b]{3}{*}{$\begin{array}{r}\text { CSFB/ } \\
\text { Tremont } \\
\text { Index }\end{array}$} & \multirow[b]{3}{*}{ Investable } & \multicolumn{6}{|c|}{ Hedge fund strategies } \\
\hline & & & & & \multirow[b]{2}{*}{$\begin{array}{r}\text { Multi- } \\
\text { Strategy }\end{array}$} & \multicolumn{3}{|c|}{ Market Neutral } & \multicolumn{2}{|c|}{ Event Driven } \\
\hline & & & & & & $\begin{array}{l}\text { Equity } \\
\text { Market } \\
\text { Neutral }\end{array}$ & $\begin{array}{r}\text { Convertible } \\
\text { Arbitrage }\end{array}$ & $\begin{array}{r}\text { Fixed } \\
\text { Income } \\
\text { Arbitrage }\end{array}$ & $\begin{array}{l}\text { ED Multi- } \\
\text { Strategy }\end{array}$ & Distressed \\
\hline \multirow{4}{*}{\multicolumn{2}{|c|}{ Bond indices }} & GBI Europe \$ & -0.10 & 0.32 & 0.20 & -0.08 & -0.10 & -0.05 & -0.18 & -0.08 \\
\hline & & GBI EMU \$ & -0.12 & 0.31 & 0.16 & -0.12 & -0.13 & -0.08 & -0.20 & -0.11 \\
\hline & & GBI US \$ & 0.12 & 0.32 & 0.01 & 0.12 & 0.06 & 0.10 & -0.13 & -0.06 \\
\hline & & GBI Global \$ & -0.07 & 0.30 & 0.15 & 0.06 & -0.10 & -0.10 & -0.18 & -0.06 \\
\hline \multirow{3}{*}{\multicolumn{2}{|c|}{ Stock indices }} & MSCI World Equity \$ & 0.47 & 0.16 & 0.12 & 0.35 & 0.10 & 0.03 & 0.51 & 0.57 \\
\hline & & S\&P 500 & 0.48 & 0.08 & 0.07 & 0.39 & 0.13 & 0.03 & 0.48 & 0.55 \\
\hline & & DJ EURO STOXX \$ & 0.45 & 0.27 & 0.19 & 0.22 & 0.11 & 0.07 & 0.49 & 0.46 \\
\hline \multirow{13}{*}{$\begin{array}{l}\text { Hedge } \\
\text { fund } \\
\text { strategies }\end{array}$} & \multirow{5}{*}{ Directional } & Long/Short & 0.78 & 0.70 & 0.15 & 0.34 & 0.26 & 0.20 & 0.64 & 0.58 \\
\hline & & Short Bias & -0.48 & -0.36 & -0.07 & -0.33 & -0.23 & -0.08 & -0.55 & -0.63 \\
\hline & & Global Macro & 0.86 & 0.53 & 0.12 & 0.21 & 0.29 & 0.45 & 0.42 & 0.31 \\
\hline & & Emerging & 0.65 & 0.46 & -0.03 & 0.22 & 0.31 & 0.29 & 0.68 & 0.59 \\
\hline & & Futures & 0.12 & 0.47 & -0.01 & 0.12 & -0.19 & -0.07 & -0.22 & -0.14 \\
\hline & \multirow{4}{*}{$\begin{array}{l}\text { Event } \\
\text { Driven }\end{array}$} & Total & 0.66 & 0.56 & 0.17 & 0.36 & 0.58 & 0.39 & 0.93 & 0.94 \\
\hline & & Risk Arbitrage & 0.39 & 0.50 & 0.07 & 0.30 & 0.40 & 0.13 & 0.65 & 0.56 \\
\hline & & Distressed & 0.57 & 0.45 & 0.12 & 0.33 & 0.50 & 0.31 & 0.76 & 1 \\
\hline & & ED Multi-Strategy & 0.68 & 0.59 & 0.21 & 0.34 & 0.59 & 0.43 & 1 & \\
\hline & \multirow{3}{*}{$\begin{array}{l}\text { Market } \\
\text { Neutral }\end{array}$} & FI Arbitrage & 0.45 & 0.31 & 0.27 & 0.07 & 0.53 & 1 & & \\
\hline & & Convertible & 0.40 & 0.38 & 0.35 & 0.32 & 1 & & & \\
\hline & & Market Neutral & 0.33 & 0.10 & 0.20 & 1 & & & & \\
\hline & & Multi-Strategy & 0.17 & 0.49 & \multirow[t]{3}{*}{1} & & & & & \\
\hline & & Investable & 0.78 & 1 & & & & & & \\
\hline & & CSFB/Tremont Index & 1 & & & & & & & \\
\hline
\end{tabular}

Sources: Datastream, Bloomberg and own calculations.

Notes: CSFB/Tremont Index and sub-indices begin in January 1994, except Multi-Strategy, which began in April 1994, and Investable, which began in January 2000. GBI EMU \$ began in January 1995 . Given 132 observation pairs (monthly returns for 11 years) and a 5\% (1\%) confidence level, statistically significant (i.e. different from zero) module values of pairwise correlation coefficients should exceed $0.17(0.22)$ 
exposures to illiquid positions and the less frequent pricing of these exposures. ${ }^{27}$

\subsection{POSSIBLE NEGATIVE EFFECTS}

The near-collapse of LTCM (see Box 2) underscores how hedge fund activities can harm financial institutions and markets. A sequence of negative events can start with losses on leveraged market positions. Liquidity shortages then come into play, which are further exacerbated by asset illiquidity in stressed markets. Thus, leveraged market risk can, if not supported by adequate liquidity reserves or borrowing capacity, force a fund to default on its obligations to prime brokers and other financial institutions. The spill-over effect on markets depends on the fund's size and the relative importance of its positions in certain markets. The sequence of negative events can also be triggered by mass exits from markets where hedge funds and proprietary trading desks of large banks have taken relatively similar positions. The concentrations, linkages and spill-over effects could therefore ultimately lead to a systemic crisis.

To structure the analysis, it is useful to distinguish three channels through which hedge funds could affect financial stability.

27 Getmansky et al. (2003).

\begin{tabular}{|c|c|c|c|c|c|c|c|c|c|c|c|c|c|}
\hline \multicolumn{7}{|c|}{ Hedge fund strategies } & \multirow{2}{*}{\multicolumn{3}{|c|}{ Stock indices }} & \multirow{2}{*}{\multicolumn{4}{|c|}{ Bond indices }} \\
\hline \multicolumn{2}{|c|}{ Event Driven } & \multicolumn{5}{|c|}{ Directional } & & & & & & & \\
\hline $\begin{array}{r}\text { Risk } \\
\text { Arbitrage }\end{array}$ & Total & $\begin{array}{r}\text { Managed } \\
\text { Futures }\end{array}$ & $\begin{array}{r}\text { Emerging } \\
\text { Markets }\end{array}$ & $\begin{array}{l}\text { Global } \\
\text { Macro }\end{array}$ & $\begin{array}{r}\text { Dedicated } \\
\text { Short } \\
\text { Bias }\end{array}$ & $\begin{array}{l}\text { Long/ } \\
\text { Short } \\
\text { Equity }\end{array}$ & $\begin{array}{r}\text { DJ } \\
\text { EURO } \\
\text { STOXX \$ }\end{array}$ & S\&P 500 & $\begin{array}{r}\text { MSCI } \\
\text { World } \\
\text { Equity } \$\end{array}$ & $\begin{array}{r}\text { GBI } \\
\text { Global \$ }\end{array}$ & GBI US \$ & $\begin{array}{r}\text { GBI } \\
\text { EMU \$ }\end{array}$ & $\begin{array}{r}\text { GBI } \\
\text { Europe } \$\end{array}$ \\
\hline-0.05 & -0.13 & 0.38 & -0.21 & -0.10 & 0.10 & 0.02 & 0.10 & -0.11 & -0.01 & 0.91 & 0.45 & 1.00 & 1 \\
\hline-0.06 & -0.16 & 0.37 & -0.24 & -0.11 & 0.11 & -0.01 & 0.08 & -0.14 & -0.03 & 0.90 & 0.44 & 1 & \\
\hline-0.12 & -0.10 & 0.37 & -0.11 & 0.23 & 0.15 & 0.04 & -0.18 & -0.10 & -0.15 & 0.61 & 1 & & \\
\hline-0.04 & -0.11 & 0.39 & -0.17 & -0.10 & 0.02 & 0.06 & 0.08 & -0.02 & 0.07 & 1 & & & \\
\hline 0.46 & 0.59 & -0.13 & 0.53 & 0.18 & -0.76 & 0.61 & 0.86 & 0.94 & 1 & & & & \\
\hline 0.45 & 0.56 & -0.19 & 0.48 & 0.23 & -0.76 & 0.59 & 0.75 & 1 & & & & & \\
\hline 0.47 & 0.52 & -0.08 & 0.44 & 0.21 & -0.58 & 0.58 & 1 & & & & & & \\
\hline 0.50 & 0.66 & -0.03 & 0.59 & 0.42 & -0.72 & 1 & & & & & & & \\
\hline-0.50 & -0.64 & 0.19 & -0.57 & -0.13 & 1 & & & & & & & & \\
\hline 0.13 & 0.37 & 0.25 & 0.41 & 1 & & & & & & & & & \\
\hline 0.42 & 0.68 & -0.10 & 1 & & & & & & & & & & \\
\hline-0.19 & -0.19 & 1 & & & & & & & & & & & \\
\hline 0.68 & 1 & & & & & & & & & & & & \\
\hline 1 & & & & & & & & & & & & & \\
\hline
\end{tabular}




\section{Chart 24 Return-to-risk ratios}

(annualised compound rate of return divided by annualised volatility of monthly returns; January 1994-December 2004 monthly data)

$$
\begin{array}{ll}
\text { Broad hedge fund indices } \\
\text { Multi-Strategy } \\
\text { Market Neutral strategies } \\
\text { ㅍII } \\
\text { Event Driven strategies } \\
\text { III } \\
\text { Directional strategies } \\
\text { Stock indices }
\end{array}
$$

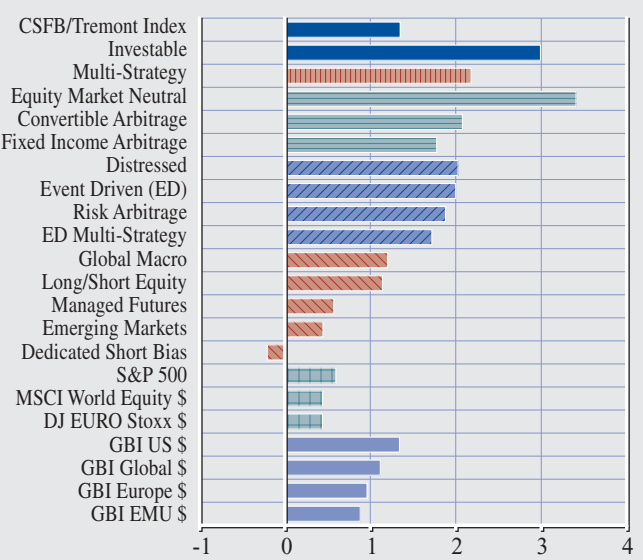

Sources: Datastream, Bloomberg and own calculations. Notes: CSFB/Tremont Index and sub-indices begin in January 1994, except Multi-Strategy, which began in Apri 1994 and Investable, which began in January 2000. GBI EMU $\$$ began in January 1995 .
First, the failure of a large individual or a group of hedge funds could lead to far-reaching repercussions for exposed banks and financial markets. Second, the serious mismanagement of exposures to hedge funds at an individual bank or banks might lead to a systemic crisis via contagion effects. Third, instability could be initiated through the impact of hedge fund activities on financial markets. A triggering event could be associated with any of these channels and instability could be further escalated by the vicious cycle of reinforcing ripple effects on other channels.

\subsection{THROUGH LEVERAGE AND LIQUIDITY RISKS OF HEDGE FUNDS}

Hedge funds obtain leverage in a number of ways, but they typically prefer derivatives and other arrangements where positions are established by posting margins rather than the full face value of a position. Repurchase agreements and short sales are also quite popular techniques. Direct credit in the form of loans is rather uncommon, but credit lines for liquidity purposes are widely used.

\section{Chart 25 Hedge fund returns and volatility}

(\%; in USD; January 1994-December 2004; monthly data)

- CSFB/Tremont Index

iil Investable

A Multi-Strategy

- Market Neutral strategies

Event Driven strategies

- - Directional strategies

annualised compound rate of return

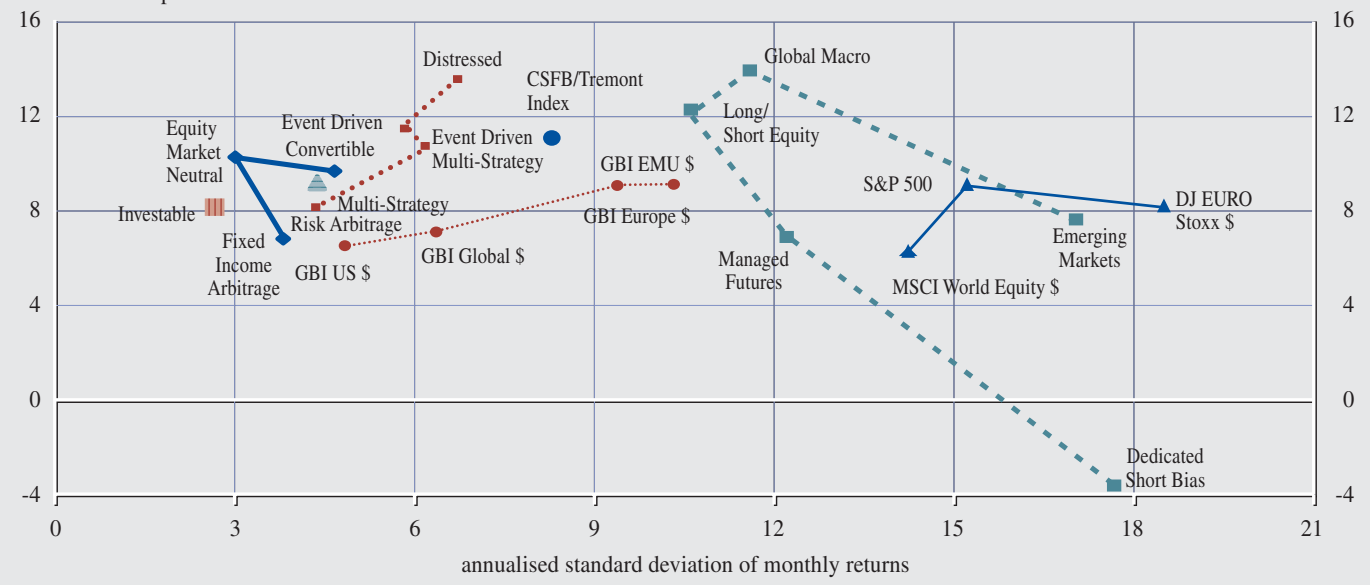

Sources: Datastream, Bloomberg and own calculations.

Notes: CSFB/Tremont Index and sub-indices begin in January 1994, except Multi-Strategy, which began in April 1994 and Investable, which began in January 2000. GBI EMU \$ began in January 1995 


\section{THE LONG-TERM CAPITAL MANAGEMENT (LTCM) EPISODE}

The near-default of LTCM in September 1998 and its fall-out on world financial markets brought hedge funds to the attention of the global financial community. LTCM was founded in early 1994 as a Delaware limited liability partnership, and its main fund, Long-Term Capital Portfolio, was domiciled in the Cayman Islands. Many prominent names from Wall Street and academia were present among its principals and investors, including Nobel Prize laureate Myron Scholes. At the beginning of 1998, LTCM managed approximately USD 4.8 billion of assets.

LTCM used sophisticated relative value arbitrage strategies in global fixed income and equity index markets. These strategies relied heavily on quantitative models and past correlations between financial market variables. LTCM managers were taking market positions on the assumption that liquidity, credit and volatility spreads would narrow from their historically high levels. For a long time this strategy worked well. A favourable macroeconomic environment, the worldwide decline in inflation and a substantial convergence in interest rates associated with the prospect of Economic and Monetary Union (EMU) all led to a substantial compression of nominal yields and risk spreads in the industrial economies. These market positions were supported by extremely high leverage, with balance sheet assets being more than 25 times higher than equity. Notwithstanding its limited disclosure, the fund's impressive track record and reputation of its principals ensured very favourable credit terms, while the large trading volume made the fund a very desirable counterparty.

The Russian debt crisis, however, caused global interest rate anomalies, as investors rushed into a "flight-to-quality" and spreads on riskier debt widened dramatically. Past correlations between financial markets broke down, LTCM investments began to lose value, and the fund was forced to unwind its positions at very unfavourable prices in order to meet margin calls and satisfy other liquidity demands. The problems were compounded by the sheer size of the LTCM positions in certain markets. At the end of August 1998, LTCM had already lost over 50\% of its equity. What started as a pure liquidity crisis could have led to default, but a meltdown was avoided when the Federal Reserve coordinated a bailout by the consortium of the fund's 14 main bankers. Insolvency would have led to even larger losses to creditors and further disruptions in then already very fragile markets.

Most of the resources provided by prime brokers to LTCM were collateralised and collateral agreements required frequent marking to market. Prime brokers therefore did not see the need to impose tight limits on current credit exposures. The LTCM case, however, highlighted the fact that market participants had failed to account for potential future credit exposures arising from the interaction of the market, market liquidity and credit risks. None of the prime brokers was aware of the full size and the riskiness of the LTCM portfolio. Advantageous credit terms evaporated quickly under stressed conditions, as creditors changed their stance dramatically, which further magnified the severity of the liquidity shortage. 


\begin{tabular}{|c|c|}
\hline \multicolumn{2}{|l|}{ Leverage measures } \\
\hline \multicolumn{2}{|l|}{ Accounting-based } \\
\hline Gross on-balance sheet leverage & Total on-balance sheet assets/Equity \\
\hline Net on-balance sheet leverage & (Total on-balance sheet assets - Matched book assets)/Equity \\
\hline Gross accounting leverage & $\begin{array}{l}\text { (Total on-balance sheet assets + Total on-balance sheet liabilities } \\
+ \text { Gross off-balance sheet transactions)/Equity }\end{array}$ \\
\hline Gross economic leverage & (Risky assets + Risky liabilities + Gross off-balance sheet notional)/Equity \\
\hline Net economic leverage & $\begin{array}{l}\text { (Risky assets }- \text { matched book assets }+ \text { Risky liabilities - Matched book liabilities } \\
+ \text { Gross off-balance sheet notional - Hedges)/Equity }\end{array}$ \\
\hline \multicolumn{2}{|l|}{ Risk-based } \\
\hline VaR leverage & VaR/Equity \\
\hline Scenario (stress) VaR leverage & Scenario (stress test) derived VaR/Equity \\
\hline Asset liquidity-adjusted VaR leverage & VaR with liquidation horizon scaled volatilities/Equity \\
\hline \multicolumn{2}{|l|}{ Liquidity measures } \\
\hline \multirow[t]{2}{*}{ Absolute liquidity } & Cash \\
\hline & Cash + Borrowing capacity \\
\hline \multirow[t]{3}{*}{ Relative measures } & Cash/Equity \\
\hline & $($ Cash + Borrowing capacity $) /$ Equity \\
\hline & VaR/(Cash + Borrowing capacity) \\
\hline
\end{tabular}

A number of possible measures of leverage are given in Table 12. Accounting-based balance sheet measures of leverage fail to reflect the risk of the assets. Risk-based measures alleviate this shortcoming by relating market risk to the capacity to absorb it. However, riskbased leverage measures, even adjusted for potential asset illiquidity, do not capture the funding liquidity risks arising from margin calls, redemptions or financing mismatches. The LTCM episode clearly underscored the role of funding liquidity in escalating the effects of otherwise acceptable losses on market positions. Hence, leveraged market risk should be evaluated in conjunction with the liquidity risk stemming from asset illiquidity and funding risks.

Data in the TASS database seem to confirm that fixed income arbitrage and convertible arbitrage strategies tend to have the highest leverage (see Chart 26 and Chart 27), although the degree of leverage in the third market neutral strategy, equity market neutral, does not seem to be very high. ${ }^{28}$ Managed futures, global macro and multi- strategy funds are also intensive users of leverage, with the first two of these strategies relying extensively on derivatives to acquire the desired exposures. As a rule, FOHFs do not seem to be highly leveraged, although some of them use leverage in excess of $200 .{ }^{29}$ FOHF products with capital protection are quite popular among risk-averse institutional investors, but the design of such products ${ }^{30}$ also implies that the FOHFs will have to employ leverage to achieve targeted returns.

28 Tremont Capital Management, the manager of the TASS database, guides hedge funds to calculate leverage as a ratio of hedge fund portfolio to equity, multiplied by 100 . There is a difference between "no leverage" and "average leverage 0" as some hedge funds indicate that they use leverage, but state that their average leverage is zero.

29 Based on Deutsche Bank's 2005 Alternative Investment Survey, $41 \%$ of FOHFs do not use leverage, $41 \%$ use leverage and $18 \%$ do not use leverage, but are interested in doing so in the future.

30 For example, $60 \%$ of attracted capital is invested in zero coupon bonds maturing after 10-12 years, and the remaining $40 \%$ is invested in underlying hedge funds. An investor is guaranteed to receive $100 \%$ of the initial investment, provided the investment is held until the maturity of the zero coupon bonds. However, $40 \%$ of the initial investment has to be invested in a way that could earn $8-12 \%$ on the $100 \%$ of initial investment; therefore, the use of leverage is inevitable. 


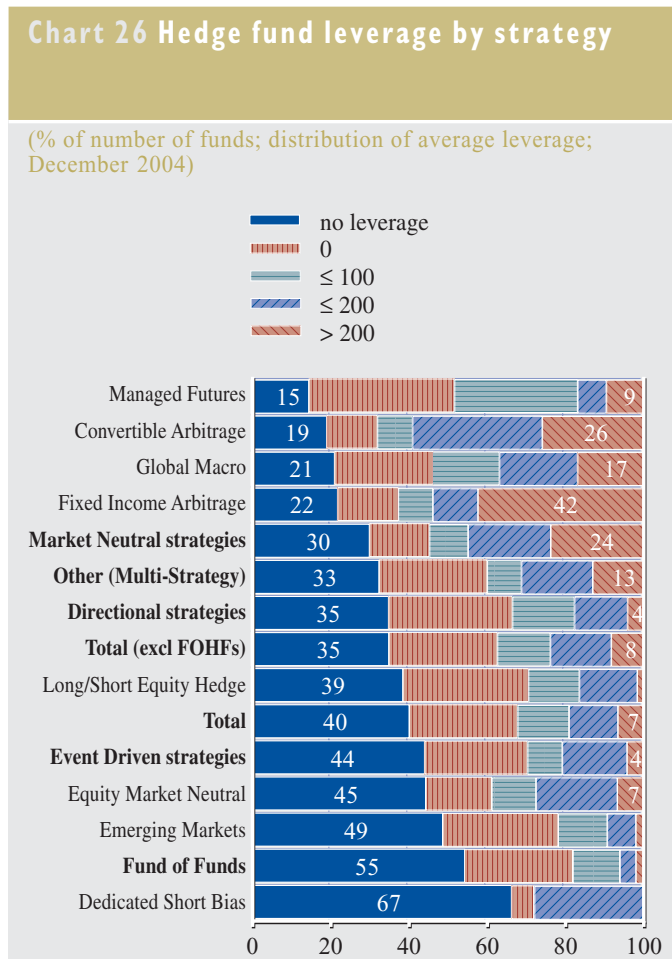

Source: TASS database ( 30 June 2005 version).

Note: Only funds with reported (estimated) capital under management.

\section{Chart 27 Hedge fund leverage by strategy}

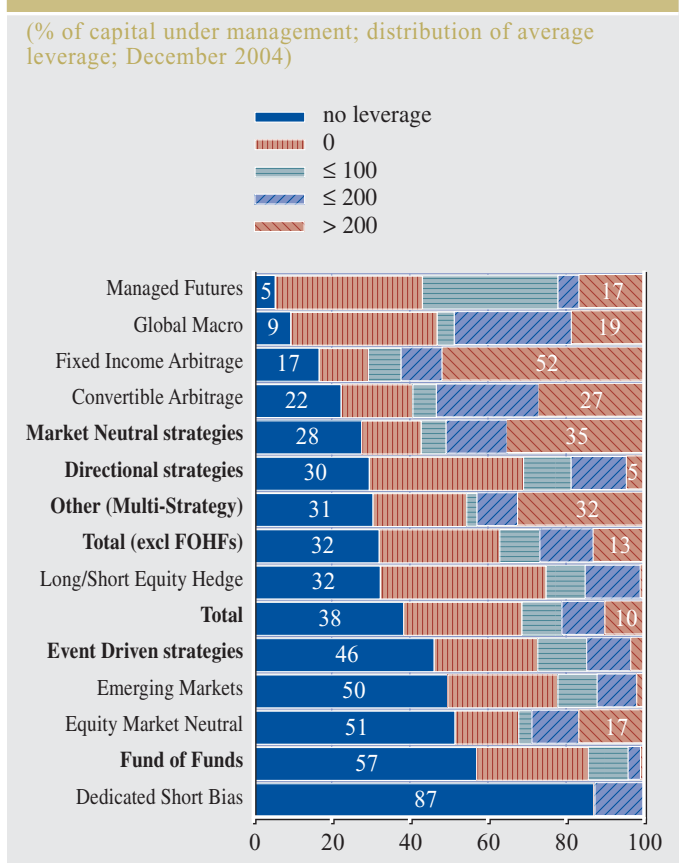

Source: TASS database (30 June 2005 version)

Note: Only funds with reported (estimated) capital under management.
6 FINANCIAL

STABILITY

IMPLICATIONS

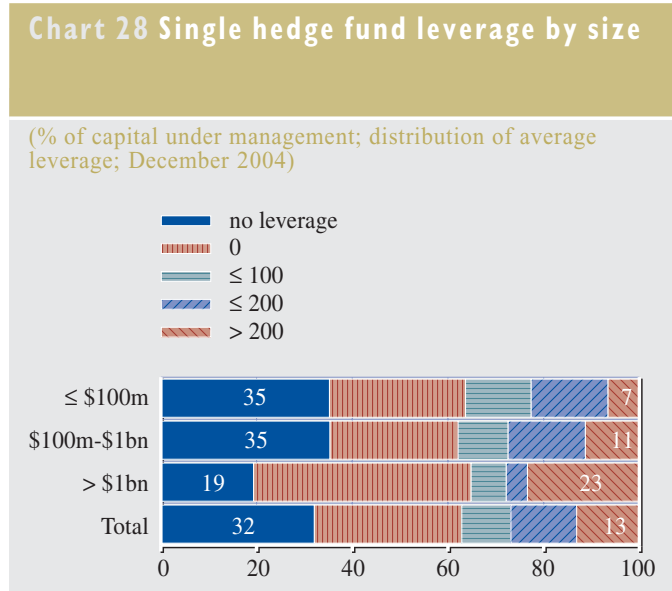

Source: TASS database (30 June 2005 version).

Note: Only funds with reported (estimated) capital under management.

\section{Chart 29 FOHF leverage by size}

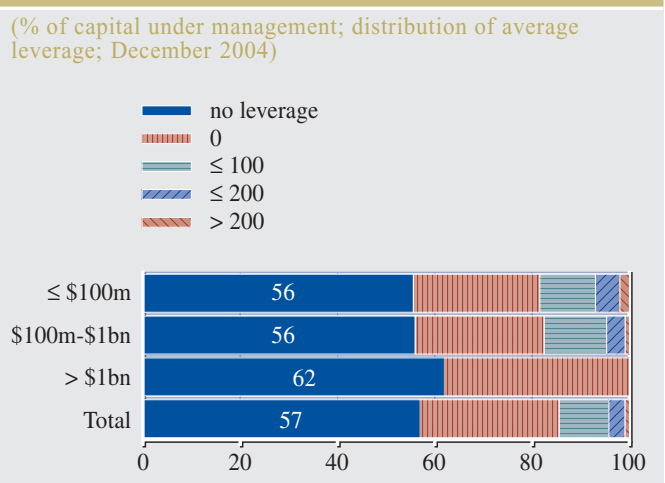

Source: TASS database (30 June 2005 version).

Note: Only funds with reported (estimated) capital under management. 


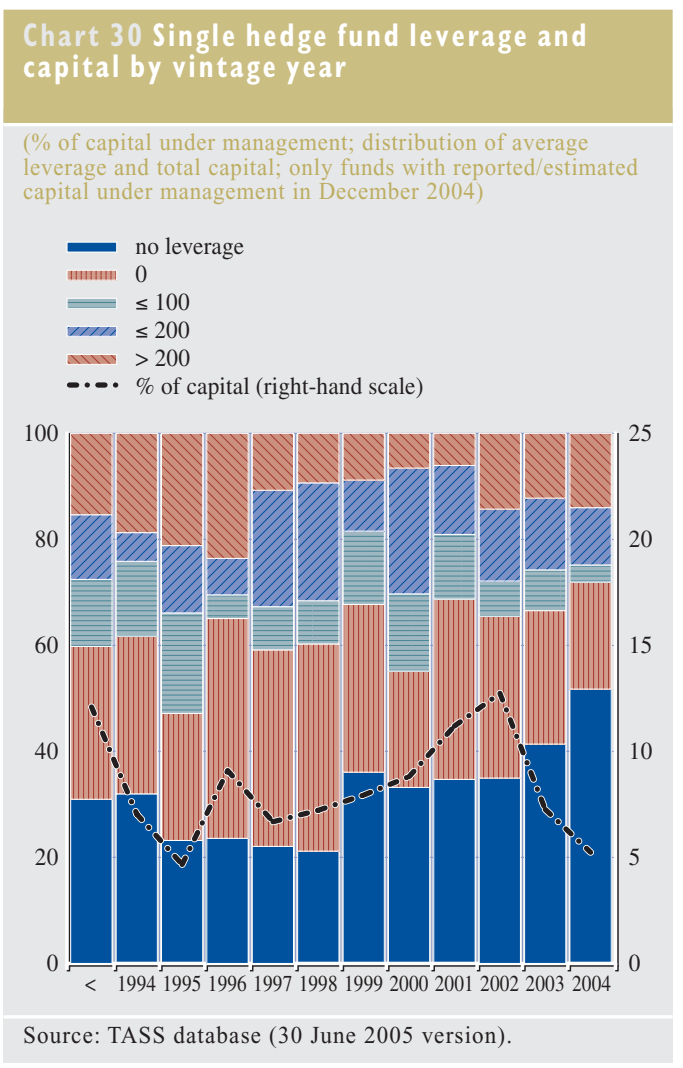

Leverage seems to vary greatly by hedge fund size, and the largest single hedge funds, with more than USD 1 billion of capital under management (51 hedge funds), tend to exhibit higher levels of leverage. In the latter group, the share of hedge fund capital with a leverage factor of more than 200 is $23 \%$ - the highest among all size groups (see Chart 28). By contrast, the largest FOHFs (14 FOHFs) do not seem to use leverage at all, although some smaller ones do (see Chart 29).

The information presented so far does not provide an insight into the evolution of leverage. Notwithstanding data limitations (see Box 1), it is possible to analyse how leverage varies among active funds with different vintage (inception) years. Interestingly, older single hedge funds, perhaps managed by more experienced managers, tend to be more leveraged than newer ones (see Chart 30 and Chart 31), providing some support for the view that

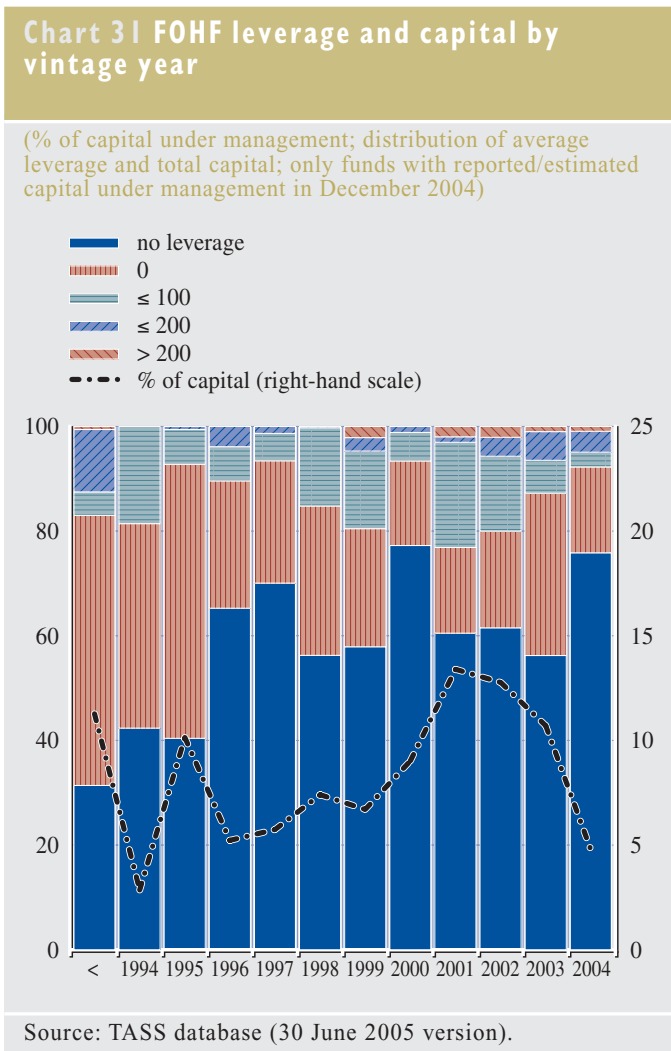

leverage across the hedge fund industry has probably declined and is presently lower than at the time of the near-failure of LTCM. ${ }^{31}$

If this prevalent view is correct, then the potential for forced liquidations of hedge fund positions in times of stress seems to be lower. With excessive leverage, even a moderate price swing could force hedge funds to liquidate their leveraged positions to meet margin calls, potentially leading to ripple effects across a number of markets. Most lending by banks is short-term, which in combination with high leverage further decreases the ability to wait until a possible price recovery. However, the analysis of a possible market impact should also incorporate the leverage and positions of proprietary trading desks of regulated banks and securities firms, since they may adopt hedge fund-like strategies.

31 The same conclusion has been reached by McGuire et al (2005) from the BIS, who used hedge fund style analysis to yield a time-varying indicators of leverage. 


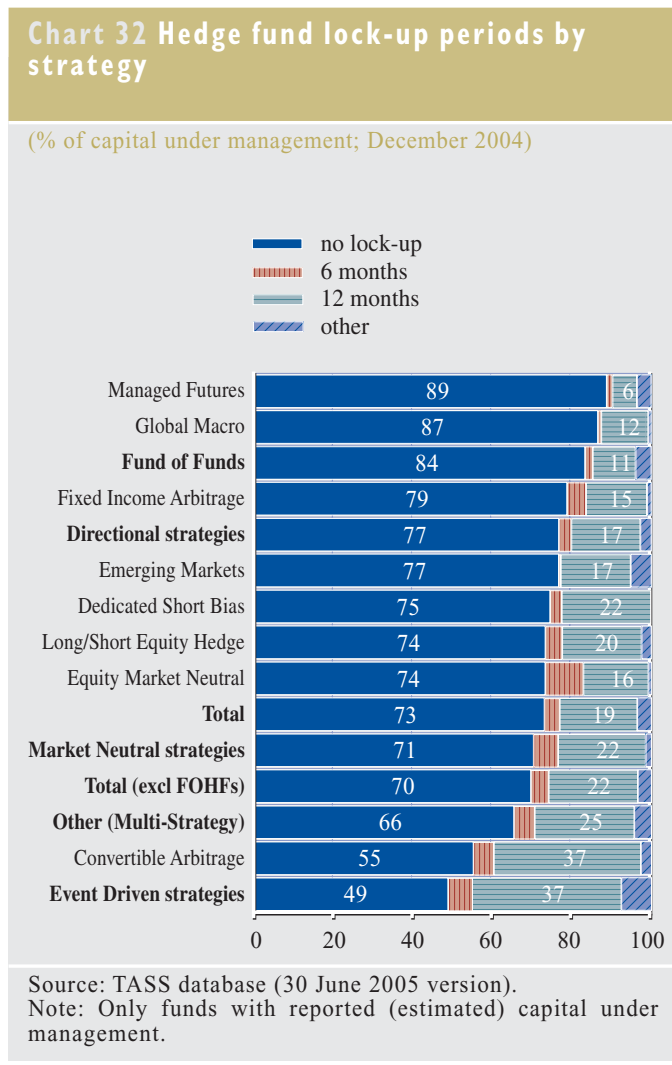

Obtaining data on hedge fund liquidity parameters is also problematic, although certain insights may nevertheless be gained by examining funding risks and in particular the vulnerability of hedge funds to sudden investor withdrawals. Compared to hedge funds, banks and securities firms have more diverse and stable sources of revenue and funding, although this may, to some extent, be offset by more inflexible cost structures and the higher amount of illiquid assets.

According to TASS data on lock-up periods, redemption frequency and redemption notice periods, managed futures and global macro funds may be relatively more vulnerable to investor panic, although their investment portfolios most likely consist of rather liquid assets (see Chart 32, Chart 34 and Chart 36). Fixed income and convertible arbitrage funds, which both use the highest leverage, are positioned broadly in line with, or even slightly better than, the overall industry.

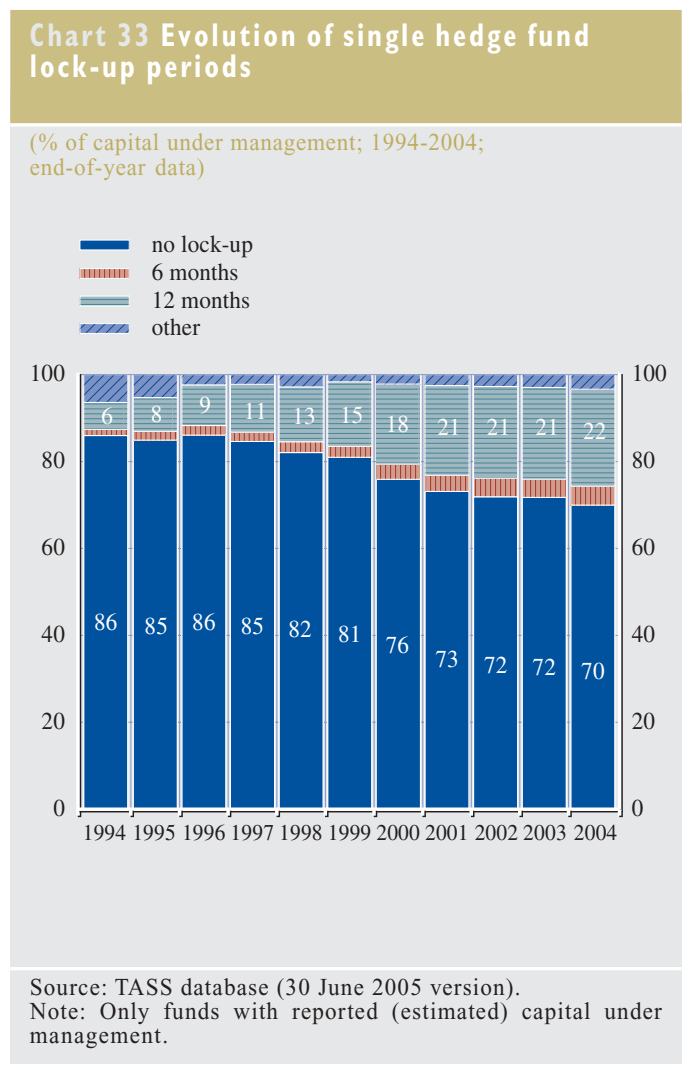

6 FINANCIAL STABILITY IMPLICATIONS

It would be prudent for hedge funds with less liquid investments to take appropriate protective measures. These could, for example, include lengthier lock-up periods, less frequent redemptions, longer redemption notice periods, and higher liquidity reserves or credit lines for unforeseen liquidity shortages. There are some indications that hedge funds specialising in market neutral and event driven strategies tend to have more illiquid and complex positions. However, according to TASS data, these strategies are also associated with longer lock-up periods, less frequent redemptions and longer redemption notice periods. The longer-term trend for the whole hedge fund industry is that lock-up periods have been slowly becoming more widespread $^{32}$ and redemption notice periods have been lengthening. At the same time, the redemption frequency has been increasing and,

32 Longer lock-ups also ensure that management fees will bring more revenue and allow hedge fund managers to promise better pay packages for the most talented traders and other professionals. 


\section{Chart 34 Hedge fund redemption frequency by strategy}

(\% of capital under management; December 2004)

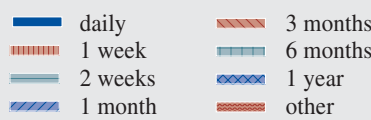

Managed Futures Global Macro

Equity Market Neutra Directional strategie Fund of Funds Long/Short Equity Hedge Emerging Markets ||||

Total
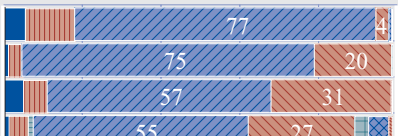

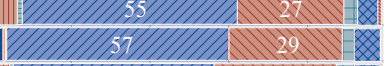

Total (excl FOHFs)

Market Neutral strategies

Fixed Income Arbitrag

Other (Multi-Strategy)

Convertible Arbitrage

Event Driven strategies

Dedicated Short Bias
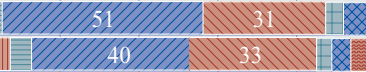

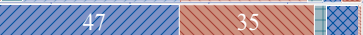
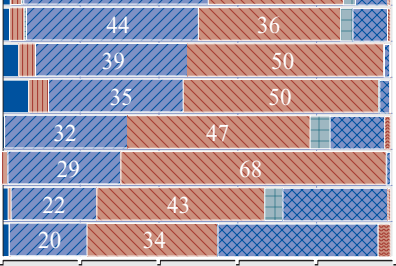

$\begin{array}{llllll}0 & 20 & 40 & 60 & 80 & 100\end{array}$

Source: TASS database ( 30 June 2005 version)

Note: Only funds with reported (estimated) capital under management.

\section{Chart 36 Hedge fund redemption notice} periods by strategy

(\% of capital under management; December 2004)
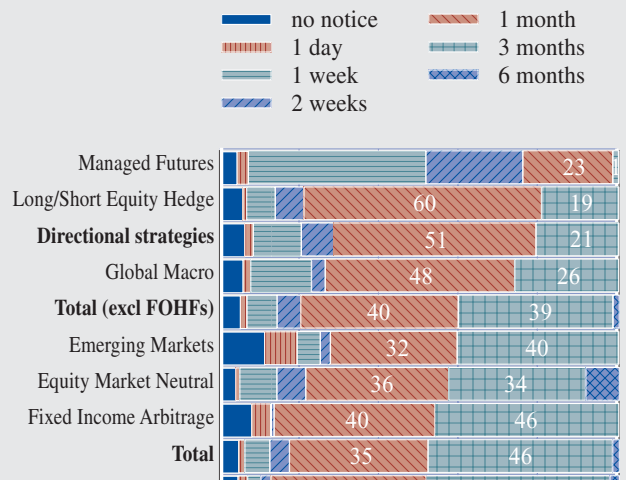

Market Neutral strategies

Dedicated Short Bias

Convertible Arbitrage $\mid$\begin{tabular}{l|l|l|}
\hline & 40 WL & 56 \\
\hline
\end{tabular}

Fund of Funds \begin{tabular}{|l|l|l|l|}
\hline 1 & 21 & 69
\end{tabular}

Other (Multi-Strategy)

Event Driven strategies |Fin

$\begin{array}{llllll}0 & 20 & 40 & 60 & 80 & 100\end{array}$

Source: TASS database (30 June 2005 version).

Note: Only funds with reported (estimated) capital under management.
Chart 35 Evolution of single hedge fund redemption frequency

(\% of capital under management; 1994-2004; end-of-year data)

$$
\begin{array}{lll} 
& \text { daily } & 3 \text { months } \\
& 1 \text { week } & 6 \text { months } \\
2 \text { weeks } & 1 \text { year } \\
1 \text { month } & \text { other }
\end{array}
$$

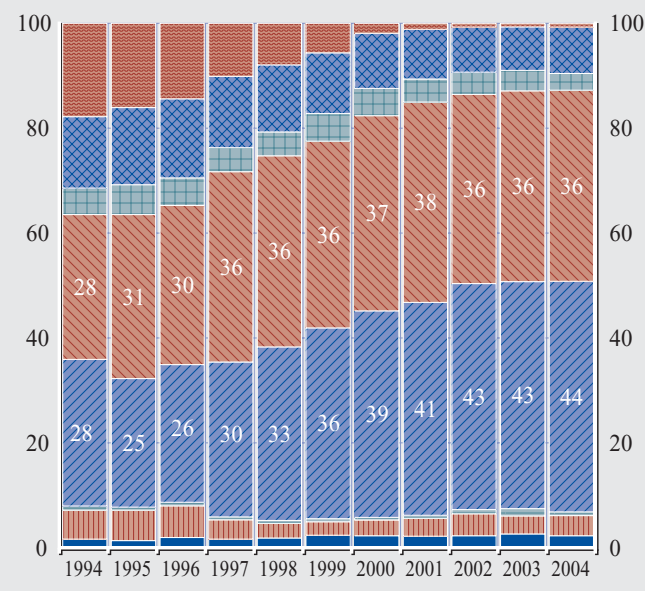

Source: TASS database (30 June 2005 version)

Note: Only funds with reported (estimated) capital under management.

\section{Chart 37 Evolution of single hedge fund redemption notice periods}

(\% of capital under management; 1994-2004;

end-of-year data)
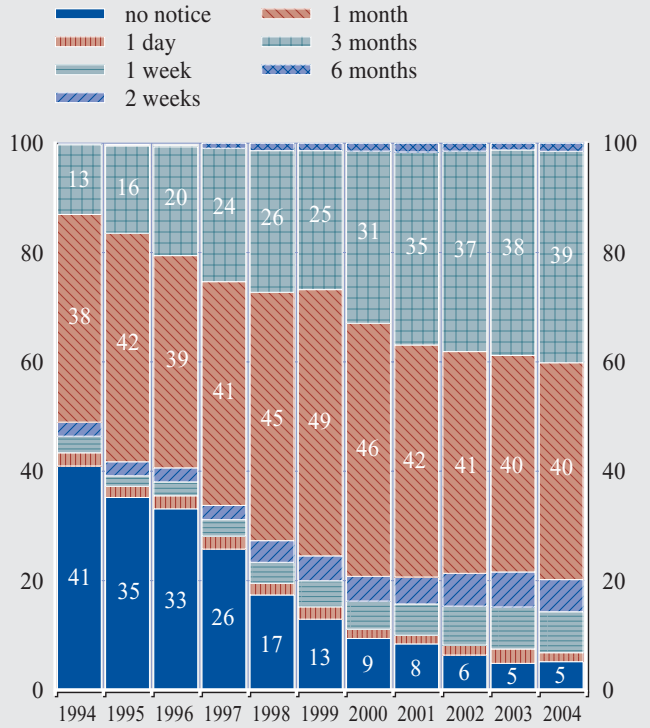

Source: TASS database (30 June 2005 version).

Note: Only funds with reported (estimated) capital under management. 
in particular, monthly and quarterly redemption frequencies are becoming an industry standard, though in combination with longer three month redemption notice periods (see Chart 33, Chart 35 and Chart 37, which assume that hedge funds' redemption profiles, as indicated in the TASS database, have been the same throughout their entire operating history).

Redemption notice periods can effectively help to lock investors' money until the second closest redemption if the investor misses the deadline in applying for the closest redemption. However, certain hedge funds also offer investors the opportunity to exit at short notice with a certain penalty (the so-called "gate" fee).

Market risk, leverage and liquidity risk may interact among each other, so a vulnerability analysis should ideally seek to identify possible combinations and concentrations of high volatility, high leverage, higher funding risks and larger hedge fund size. For illustration, a comparison of volatilities of hedge fund, stock and bond market returns is presented in Chart 38. It is, however, based on monthly returns and may not represent the true riskiness of hedge fund portfolios.

There are concerns that prolonged periods of mediocre performance may encourage hedge fund managers to employ greater leverage or more aggressive strategies. Capital could flow out following poor performance, so that hedge funds would be forced to liquidate positions. This could lead to a market-wide disinvestment spiral, potentially resulting in systemic risk.

A number of mitigating factors are, however, also at play. Institutional investors and FOHFs, which already account for half of the capital managed by hedge funds, should now have a better understanding of hedge fund operations. Hence, they may be more patient when confronted with temporary underperformance. Moreover, lengthy lock-up periods and less frequent redemption schedules could provide more time for hedge funds to recoup past shortfalls and settle their liabilities. However, the proliferation of FOHFs, which generally provide the possibility of monthly redemption, could mean that more flexible redemption profiles may be demanded from the underlying hedge funds. Some of the institutional investors that only recently started investing in hedge funds may also be less willing to accept lower liquidity of their allocations to hedge funds. ${ }^{33}$ Thus, the hedge fund industry may risk losing one of its defensive features, i.e. lengthy lock-up periods and infrequent redemption possibilities.

\subsubsection{THROUGH IMPACT ON CREDIT INSTITUTIONS}

\section{a. Direct risks}

Direct credit exposures of credit institutions and securities firms (prime brokers) to hedge funds are the most obvious channel whereby hedge funds could affect the robustness of the financial system. Prime brokers provide leverage, issue credit lines and have trading exposures to hedge funds in OTC and other markets. As credit institutions are key lenders to hedge funds, one could argue that the systemic risk posed by hedge funds could be lowered through prudent risk management. In addition to credit and trading exposures, other types of direct exposures include income flow derived from prime brokerage and other hedge fund-related services and direct market risk exposure, as banks invest their own money into hedge funds as well.

Little information on direct exposures is available to evaluate the impact of hedge funds on prime brokers. Publicly available information provided by prime brokers is very limited, although improved disclosure by financial institutions with regard to their

33 According to Deutsche Bank's 2005 Alternative Investment Survey, around $80 \%$ of FOHFs and banks, consultants, corporations and insurance companies stated that, for them, maximum preferred lock-up periods were one year or less. Family offices/high net worth individuals, pension funds, endowments and foundations were slightly more willing to accept longer lock-up periods. 
dealings with hedge funds was one of the most important recommendations after the LTCM crisis. ${ }^{34}$ Better transparency was and still is seen as one of the main instruments to make market discipline effective and for preventing future systemic disruptions.

A very rough indication of banks' direct exposures towards hedge funds can be obtained by examining Bank for International Settlements (BIS) data on consolidated bank claims on private non-bank borrowers in offshore centres (see Chart 39). ${ }^{35}$ These exposures have been growing approximately in line with the growth of the hedge fund industry. At the end of 2004, the exposures of EU15 banks to non-banks in offshore centres constituted half of all reporting banks' exposures to non-bank borrowers in offshore financial centres and about $70 \%$ of total EU15 banks' exposures to offshore financial centres.

In addition to the BIS data, certain information on prime broker exposures to hedge funds can be obtained from commercial hedge fund databases that provide information on prime brokers selected by hedge funds. Table 13 and Table 14 analyse the market shares and exposures of the largest prime brokers based on the TASS database (around two-thirds of hedge funds provide information on their prime brokers). These tables give some guidance as to the magnitude, concentration and risk of exposures to hedge funds by selected prime brokers, and could be used by supervisors as a starting point for the closer examination of prime brokers' relations with hedge funds. Some prime brokers seem to be more concentrated in a few hedge fund strategies and may therefore be more vulnerable to disruptions in certain markets.

The prime brokerage business is itself highly concentrated. Two firms, Morgan Stanley and Goldman Sachs, control more than $40 \%$ of total European and global hedge fund clients' capital under management (see Chart 40). The estimated global market share of Bear Stearns, the third largest prime broker, is in excess of
$10 \%$, although the firm's market share appears to be substantially lower if only European hedge funds are considered. Other prime brokers in the European top 10, which includes two Swiss banks and at least two EU banks, clearly lag behind the leaders. However, tight competition in 2004 led to a reduction in the market shares of the largest prime brokers.

Some of the largest prime brokers, primarily the US ones, have become very dependent on the income stream from prime brokerage services to hedge funds. In some cases, such income is reported as making up more than a quarter of their trading and commission income or an eighth of total revenue. Many banks have also increased their own trading activities, as evidenced by the higher $\mathrm{VaR}$ numbers reported recently. The appetite to take on more risk is probably related to the less volatile market conditions and the insufficient growth of other traditional income sources.

Strong competition for hedge fund business sometimes results in a situation where the prime brokers have to provide seed capital for a hedge fund and its management firm in order to establish a prime brokerage relationship. However, such investments can also improve the prime broker's own profitability via higher returns and lucrative hedge fund management fees.

Furthermore, there are some signs that tight competition has an impact on the terms of bank credit to hedge funds. Credit has become more available and hedge funds can negotiate better access to credit, both for their regular business and for unexpected liquidity shortages. Hedge funds have also managed to achieve more favourable collateral terms for their trading business, as there are indications that banks more often trade with hedge funds on a variation margin only, i.e. without requiring an initial margin. Moreover, established prime brokers

\footnotetext{
34 US President's Working Group on Financial Markets (1999). 35 However, this estimation is subject to reservations owing to the fact that claims on non-banks may comprise substantial claims on special purpose vehicles and other non-hedge fund entities domiciled offshore.
} 
Chart 38 Volatility of hedge fund, stock and bond market returns

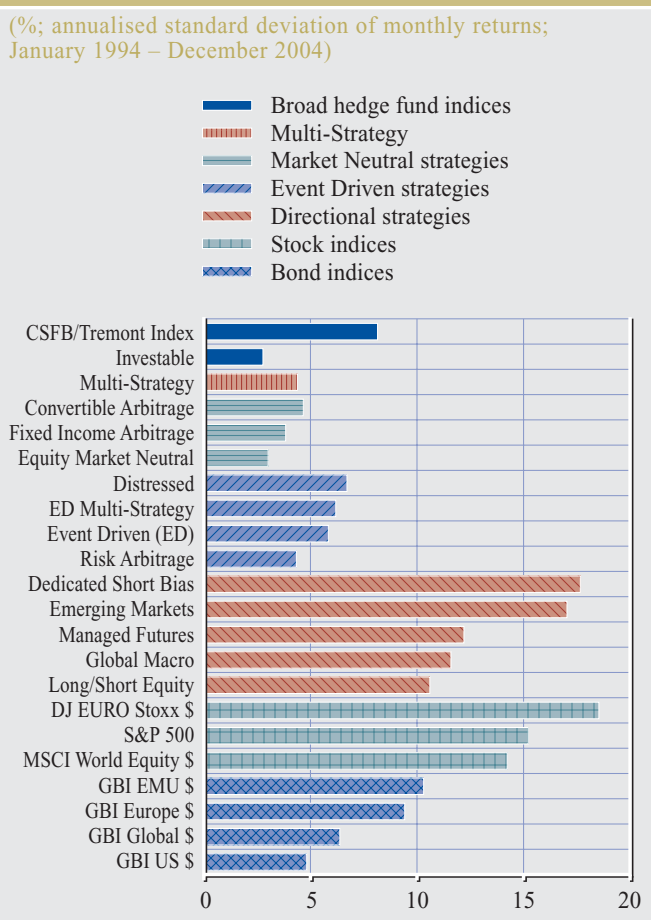

Sources: Datastream, Bloomberg and own calculations. Notes: CSFB/Tremont Index and sub-indices begin in January 1994, except Multi-Strategy, which began in April 1994, and Investable, which began in January 2000. GBI EMU \$ began in January 1995 . indicate that there has been some erosion in credit standards by new entrants to the prime brokerage business.

However, risk management practices, particularly the management of counterparty risk, appear to have improved significantly since the near-failure of LTCM. Most financing exposures to hedge funds are collateralised, and the largest banks make extensive use of VaR measures and stress tests to quantify potential future credit exposures and to protect themselves, particularly their trading exposures, from an LTCM-type scenario or other extreme events. Notwithstanding this the incorporation of asset illiquidity considerations into various risk measures remains the near-term challenge for risk managers. The information flow from most hedge funds to banks has improved, although its diversity complicates aggregation for risk management purposes. Prime brokers seem to believe that the combination of greater transparency and collateral enables them to manage hedge fund-related risks properly.

Nevertheless, there is the risk that in a highly competitive environment, risk management standards will be lowered to an inadequate

\section{Chart 39 Consolidated bank claims on private non-banks in offshore financial centres}

(amounts outstanding; USD billion; 1995-2004; quarterly data)

11 reporting banks

-.... EU15 banks

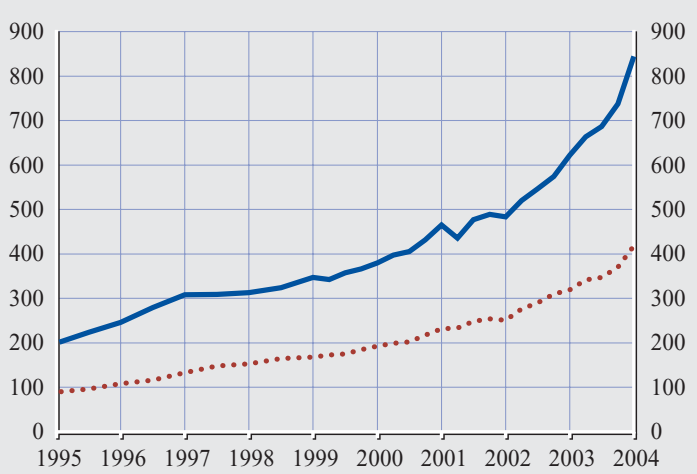

(EU15 banks; in \% of claims outstanding; December 2004)

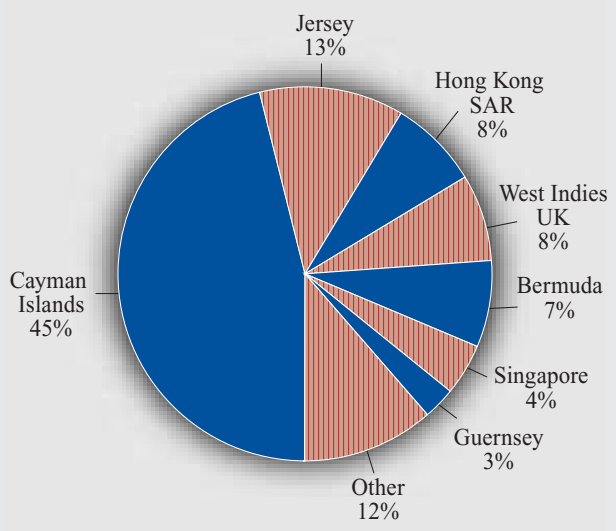

Source: BIS 
Table 13 Concentrations and exposures of selected prime brokers by the number of hedge funds (number of hedge funds; December 2004)

Selected prime brokers (sorted by total capital under management of hedge funds)
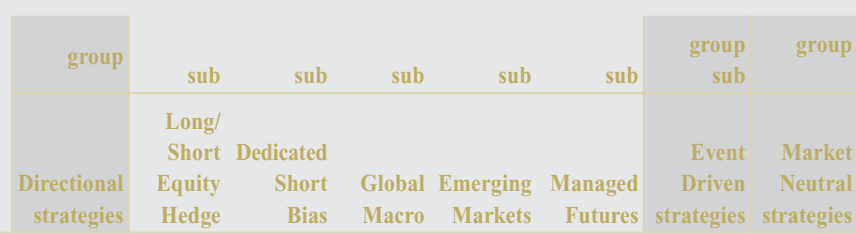

287

Bear Stearn

112

Goldman Sachs

Citigroup

ABN AMRO

Lehman Brothers

Merrill Lynch

Deutsche Bank

UBS

Banc of America

MAN Group

Crédit Agricole

CSFB

JPMorgan Chase

Refco

Barclays

SEB

Banque Populaire

245

Bias Macro

$\begin{array}{lrr}\text { bal Emerging Managed Driven Neutral Income Convertible } & \text { Market } \\ \text { ro Markets Futures strategies strategies Arbitrage Arbitrage } & \text { Neutral }\end{array}$

HSBC

NCB
KBC
AIG
Bank of Ireland
Société Générale
ING

All selected prime brokers $\quad 1,120$

Others (including

undisclosed)

$\begin{array}{rr}230 & 197 \\ 20 & \end{array}$

38

23

$18 \quad 14$

$31 \quad 23$

$69 \quad 52$

$105 \quad 102 \quad 2$

7
12
19
5
1

\section{Total number of hedge funds}

in the database

Selected EU prime brokers, $\%$

Selected US prime brokers, $\%$

CR1 of selected prime

brokers, $\%$

36

$19 \quad 15$

3

11

$8 \quad 80$

$85-30$

$\begin{array}{ll}25 & 31 \\ 35 & \end{array}$

$\begin{array}{llllll}6 & 40 & 53 & 3 & 21 & 29\end{array}$

$\begin{array}{llllll}5 & 8 & 2 & 12 & 32\end{array}$

2

$\begin{array}{rrrr}1 & 7 & 1 & 18 \\ 6 & & 1 & 4 \\ 2 & & 2 & 3\end{array}$

$\begin{array}{rrrr}1 & 7 & 1 & 18 \\ 6 & & 1 & 4 \\ 2 & & 2 & 3\end{array}$

$\begin{array}{lll}2 & 3 \\ 20 & 5 & 2\end{array}$

$\mathrm{CR} 3$ of selected prime

brokers, $\%$

Volatility, ${ }^{11}{ }^{1)}$

$27 \quad 1$

$31 \quad 21$

$\begin{array}{ll}7 & 2\end{array}$

19

19

$\begin{array}{rrrr}20 & 5 & 7 & 8 \\ 10 & 4 & 1 & 5 \\ 21 & 1 & 8 & 12 \\ 15 & 3 & 1 & 11 \\ 10 & & & 10\end{array}$

Sources: TASS database ( 30 June 2005 version) and own calculation

Notes: Only funds with reported (estimated) capital under management. If several prime brokers were provided by a hedge fund, then only the first indicated prime broker was used.

CR1 - the share (concentration ratio) of the largest prime broker or sub-strategy.

CR3 - the share (concentration ratio) of the three largest prime brokers or sub-strategies.

1) CSFB/Tremont Hedge Fund Index and sub-indices, annualised standard deviation of monthly returns, January 1994-December 2004. 
$\begin{array}{lllllllllllllllll}15 & 10 & 398 & 62 & 76 & 30 & 37 & 11 & 16 & 5 & 24 & 12 & 19 & 15 & 64 & 34 & 2\end{array}$

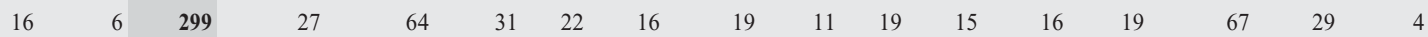

$\begin{array}{llllllllllllllll}12 & 6 & 341 & 58 & 78 & 35 & 27 & 11 & 22 & 5 & 18 & 10 & 23 & 13 & 63 & 35\end{array}$

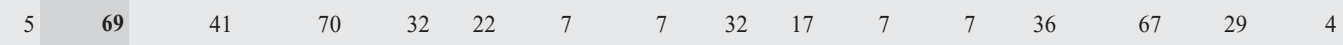

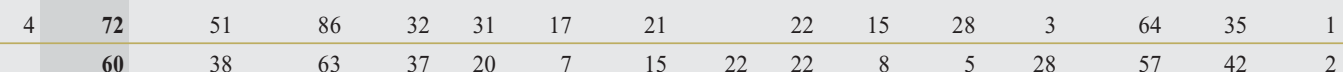

$\begin{array}{llllllllllllllll}4 & 4 & 39 & 36 & 59 & 15 & 28 & 26 & 18 & 13 & 26 & 5 & 36 & 18 & 59 & 31\end{array}$

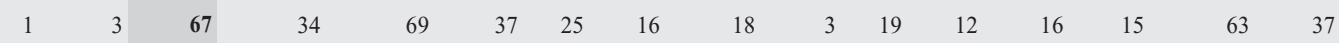

$\begin{array}{llllllllllllllll}4 & 98 & 53 & 74 & 28 & 40 & 12 & 15 & 5 & 22 & 12 & 20 & 17 & 80 & 19 & 1\end{array}$

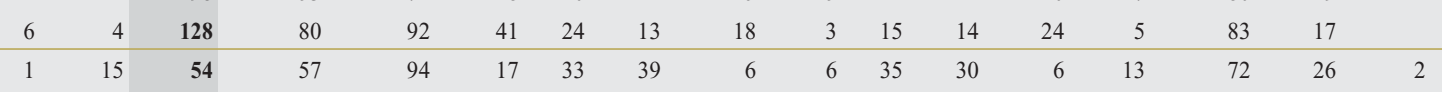

$\begin{array}{llll}5 & 34 & 56 & 91\end{array}$

$\begin{array}{lllllll}4 & 3 & \mathbf{5 3} & 40 & 70 & 36 & 25\end{array}$

$\begin{array}{lllllllllllll}3 & \mathbf{1 1} & 45 & 91 & 73 & 9 & 18 & 9 & 18 & 55 & 36 & 9\end{array}$

$\begin{array}{llllllllllll} & 25 & 100 & & 75 & 25 & 25 & & 25 & 50 & 75 \\ & 7 & 43 & 100 & 43 & 57 & & 29 & 29 & & 43 & 57\end{array}$

$\begin{array}{lllllll}1 & 14 & 15 & 93 & 100 & 13 & 87\end{array}$

$\begin{array}{llll}29 & 29 & 43 & 57 \\ 60 & 27 & 67 & 33\end{array}$

$\begin{array}{llll}57 & 100 & 86 & 14 \\ 83 & 100 & 17 & 17\end{array}$

$\begin{array}{ll}14 & \\ 17 & 67\end{array}$

$\begin{array}{ll}29 & 71 \\ 33 & 67\end{array}$

$\begin{array}{rrrrrrrrrrr}5 & 40 & 80 & 20 & 40 & 40 & 20 & 20 & 60 & \end{array}$

\begin{tabular}{|c|c|c|c|c|c|c|c|c|c|c|c|c|c|}
\hline 7 & 10 & 70 & 90 & 60 & 30 & & 10 & & 30 & & & 10 & 60 \\
\hline 4 & 37 & 62 & 86 & 5 & 38 & 38 & 11 & 8 & 35 & 27 & 14 & 19 & 97 \\
\hline
\end{tabular}

\begin{tabular}{|c|c|c|c|c|c|c|c|c|c|c|c|c|c|c|}
\hline & 14 & 57 & 100 & 29 & 29 & 36 & 7 & & 14 & 43 & 14 & & 79 & 21 \\
\hline 10 & & 44 & 63 & 31 & 29 & 15 & 17 & 8 & 21 & 14 & 18 & 16 & 67 & 31 \\
\hline
\end{tabular}

$\begin{array}{llllllllllllllllll}39 & 768 & \mathbf{1}, \mathbf{4 0 2} & 55 & 74 & 53 & 25 & 10 & 6 & 5 & 19 & 11 & 8 & 8 & 68 & 31 & 2\end{array}$

$\begin{array}{rrrrrrrrrrrrrrrrr}\mathbf{1 1 6} & \mathbf{8 7 6} & \mathbf{3 , 2 6 4} & \mathbf{3 1} & \mathbf{6 7} & \mathbf{4 0} & \mathbf{2 8} & \mathbf{1 3} & \mathbf{1 2} & \mathbf{7} & \mathbf{2 0} & \mathbf{1 3} & \mathbf{1 4} & \mathbf{1 3} & \mathbf{6 7} & \mathbf{3 1} & \mathbf{2} \\ 8 & 7 & \mathbf{1 0} & 24 & 66 & 24 & 33 & 26 & 13 & 4 & 27 & 25 & 13 & 11 & 66 & 32 & 2 \\ 52 & 5 & \mathbf{4 2} & 48 & 68 & 32 & 28 & 13 & 18 & 9 & 20 & 12 & 19 & 17 & 66 & 31 & 3\end{array}$

$14 \quad 20 \quad 12$

$\begin{array}{rrr}37 & 23 & 32 \\ 4.4 & - & 8.1\end{array}$ 


\section{Table I 4 Concentrations and exposures of selected prime brokers by the capital of hedge funds}

\section{(USD billion; December 2004)}

Selected prime brokers

(sorted by total capital

under management of

hedge funds)

Morgan Stanley

Bear Stearns

Goldman Sachs

Citigroup

ABN AMRO

Lehman Brothers

Merrill Lynch

Deutsche Bank

UBS

Banc of America
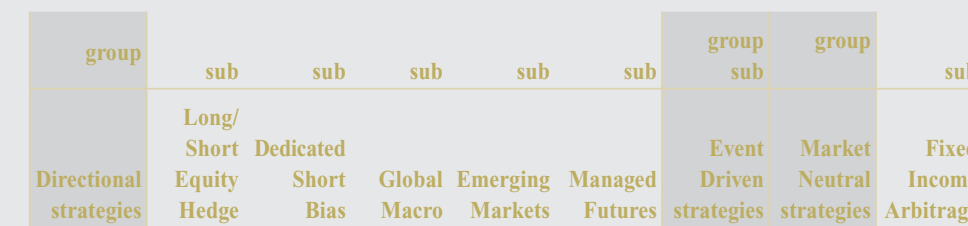

sub

sub sub

MAN Group

Crédit Agricole

quity Shor

Global Emerging Managed

Fixed

uity

Driven Neutral Income Convertible Market

Hedge Bias Macro Markets Futures strategies strategies Arbitrage Arbitrage Neutral

CSFB 2.0

JPMorgan Chase $\quad 0.7$

Refco

$8.8 \quad 4.7$

4.4

$\begin{array}{lll}0.1 & 0.4 & 3.6\end{array}$

2.1

$\begin{array}{llllll}.1 & 4.2 & 4.7 & 0.3 & 2.2 & 2.3\end{array}$

$29.3 \quad 25.8$

$\begin{array}{lll}0.5 & 2.3 & 0.8\end{array}$

$0.5 \quad 22.5$

$11.9 \quad 4.0$

5.6

2.2

$\begin{array}{lll}25.8 & 0.2 \quad 2.2\end{array}$

1.0

$0.1 \quad 7.2$

$10.8 \quad 0.3$

7.3

6.2

$\begin{array}{lll}6.9 & 6.3 & 0.0 \\ 3.8 & 3.3\end{array}$

$\begin{array}{ll}0.8 & 0.7\end{array}$

$\begin{array}{lll}0.0 & 3.2 & 7.4\end{array}$

$\begin{array}{ll}7.3 & 0.0\end{array}$

0.0

0.5

0.1

3.8
0.2

$\begin{array}{ll}0.1 & \\ 3.8 & 1.4\end{array}$

$\begin{array}{llll}0.2 & 0.3 & 0.2 & 3.8 \\ 0.4 & 1.9 & 2.5\end{array}$

1.4

$0.4 \quad 0$.

$\begin{array}{lll}6.5 & 0.0 & \\ & & 0.3\end{array}$

0.0

3.5

$0.7 \quad 0.0$

0.4
0.0

$\begin{array}{lll}.0 & 0.1 & 0.5\end{array}$

3.5
3.4

0.3

$\begin{array}{ll}0.3 & 0.0\end{array}$

1.3

0.4

0.3

0.0

$0.8 \quad 0.2$

SEB

$2.1 \quad 0.0$

0.0

0.6

2.1

\section{Banque Populaire}

HSBC

$\mathrm{NCB}$

$\mathrm{KBC}$ 0.2

\begin{tabular}{|c|c|c|c|c|c|c|}
\hline AIG & 1.2 & 0.1 & 0.0 & & 1.1 & 0.1 \\
\hline Bank of Ireland & 0.4 & 0.1 & & 0.2 & 0.0 & \\
\hline Société Générale & 0.9 & 0.0 & 0.0 & & 0.9 & 0.1 \\
\hline ING & 0.4 & 0.3 & & 0.0 & & \\
\hline
\end{tabular}

\begin{tabular}{|c|c|c|c|c|c|c|c|c|c|c|c|}
\hline Société Générale & 0.9 & 0.0 & & 0.0 & & 0.9 & & 0.1 & & & 0.1 \\
\hline ING & 0.4 & 0.3 & & & 0.0 & & 0.5 & & & & \\
\hline All selected prime brokers & 138.3 & 102.5 & 0.8 & 10.3 & 9.5 & 15.2 & 47.6 & 51.1 & 18.3 & 17.8 & 15.0 \\
\hline
\end{tabular}
undisclosed)

Total capital of hedge funds

in the database

Selected EU prime brokers, $\%$

Selected US prime brokers, $\%$

$47.6 \quad 21$.

$185.9 \quad 123.5$

$23.5 \quad 0.9$

$0.9 \quad 17.8$

$\begin{array}{lll}7.5 & 13.3 & 5.7\end{array}$

12.7

CR1 of selected prime

brokers, $\%$

CR3 of selected prime

brokers, $\%$

Volatility, $\%^{1)}$

$\begin{array}{rrr}13 & 10 & 2 \\ 58 & 70 & 89\end{array}$

$\begin{array}{rr}17.8 & 22.8 \\ 9 & \end{array}$

$22.8 \quad 20$

$20.9 \quad 60.3$

$12.7 \quad 22.6 \quad 14.0$

\section{8}

0.2

Sources: TASS database ( 30 June 2005 version) and own calculations

Notes: Only funds with reported (estimated) capital under management. If several prime brokers were provided by a hedge fund, then only the first indicated prime broker was used.

CR1 - the share (concentration ratio) of the largest prime broker or sub-strategy.

CR3 - the share (concentration ratio) of the three largest prime brokers or sub-strategies.

1) CSFB/Tremont Hedge Fund Index and sub-indices, annualised standard deviation of monthly returns, January 1994-December 2004. 
Fund of Total of sub- of sub- not use

$\begin{array}{llllllllllllllll}68 & 5 & 46 & 40 & 68 & 29 & 32 & 10 & 14 & 13 & 22 & 12 & 15 & 21 & 14 & 62\end{array}$




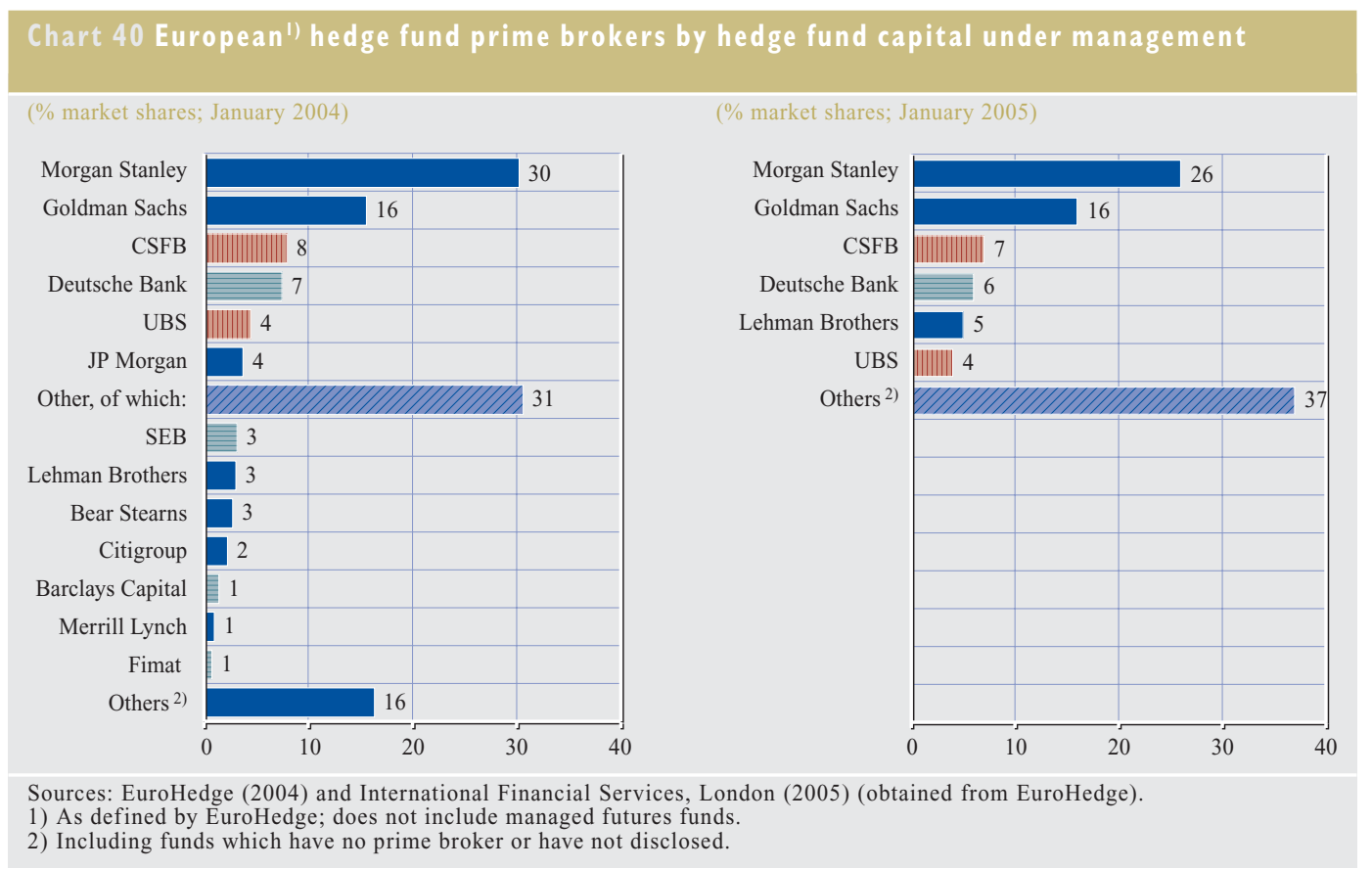

level. Since the prime brokerage business is quite concentrated, it should be relatively easier for supervisors to monitor their activities and to detect any substantial erosion of risk management standards.

Hedge funds, particularly the larger ones, prefer to use more than one prime broker to diversify counterparty base, ensure pricing efficiency and protect their proprietary trading strategies (see Chart 41). The rapidly evolving hedge fund needs, portfolio-level margining and incentives provided by prime brokers can nevertheless induce them to rely on the services of just one prime broker. However, most of the time credit providers do not have a full picture on a daily basis of the positions and risks faced by a hedge fund as a whole. This might also support the calling for more active information exchange among regulatory authorities, in addition to the gathering of more focused information from local prime brokers.

Prime brokers have been increasingly setting up in-house hedge funds in order to retain employees and to satisfy investor demand.
Quite often, former employees choose their former bank as a prime broker, which could affect the risk management standards applied. Reputation and legal risks may also arise because of dealing with unregulated and opaque entities or customers complaining about losses on investments in hedge funds commercialised by the bank.

\section{b. Indirect risks}

Apart from direct risks, credit institutions and securities firms face a number of indirect risks stemming from hedge fund activities. Indirect credit risk may arise because of credit risk visà-vis counterparties with large exposures on hedge funds. To materialise, such indirect risk does not necessarily require the default of a financial institution, as even payment problems involving a major prime broker could affect the stability of the global financial system.

Moreover, the value of market positions in prime broker portfolios may be adversely affected by hedge fund actions in financial markets, as the next sub-section discusses. Indeed, dislocations in financial markets could 
be an important indirect threat, as witnessed by the events around the time of the near-default of LTCM.

Finally, prime brokers may lose income from their own asset management business if hedge funds continue to expand. However, banks seem to be taking the threat of hedge funds seriously and are ready to adjust their business strategies accordingly.

\subsubsection{THROUGH IMPACT ON FINANCIAL MARKETS}

Hedge funds adopt active, opportunistic and sometimes leveraged trading strategies. They turn their portfolios over far more frequently than traditional funds, so their short-term influence on markets can be larger than the actual capital under management would indicate. Hedge funds generally prefer liquid and "anonymous" markets, which can be entered and exited swiftly at low cost. Their actions tend to be sporadic and, in contrast to traditional funds, they do not need to be fully invested all the time.

The impact of hedge funds on financial markets has been long debated, and efforts to estimate the impact are hampered by the lack of data

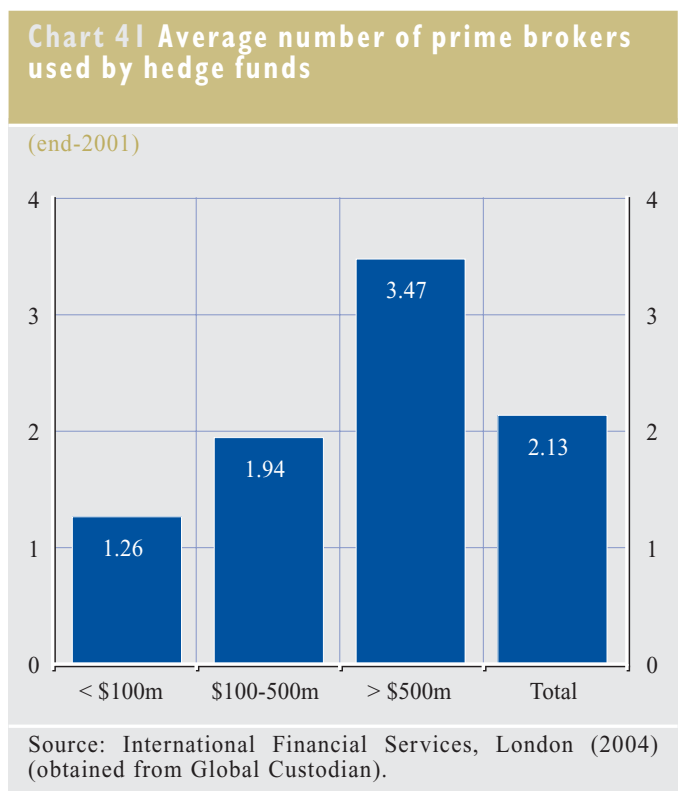

with sufficient quality. Nevertheless, the descriptions of various past episodes where hedge funds were reportedly involved can be found in a number of reports by international organisations. Most of them relate to macro hedge funds, which try to exploit doubts about the sustainability of unsound macroeconomic policies, or probe shaky currency pegs. In some cases, there were suspicions that hedge funds had compromised market integrity by allegedly engaging in manipulation, collusion or other possibly unfair trading practices. However, it is very difficult to draw the line between seemingly manipulative trades and rational economic behaviour. For example, the Financial Stability Forum (FSF) in its report on highly leveraged institutions ${ }^{36}$ declined to conclude that hedge funds had compromised market integrity in episodes it analysed, because their true motives were unknown and very difficult to prove. Moreover, quite often it were international or domestic large financial institutions and domestic investors, and not hedge funds, which led or precipitated market crashes.

Under normal conditions, hedge funds contribute to the liquidity and efficient functioning of financial markets. However, in certain cases, especially in small or mediumsized markets, their actions can be destabilising. Policymakers should therefore aim at widening the investor base of their markets, as this diminishes the risk of abrupt developments prompted by high speculative activity or the mass exit of short-term investors, such as hedge funds. Against this background, the fact that the BIS has started publishing Hirschman-Herfindahl concentration indices for a number of OTC markets represents a welcome development. Information on concentration in these and other somewhat opaque markets can provide an early warning signal regarding the build-up of concentrated positions in certain markets, and can alert market participants to the risks involved.

36 Financial Stability Forum (2000).
6 FINANCIAL STABILITY IMPLICATIONS 


\begin{tabular}{|c|c|c|c|c|c|c|c|c|}
\hline \multicolumn{9}{|l|}{ (December 2004) } \\
\hline \multirow[b]{2}{*}{ Strategy } & \multirow[b]{2}{*}{$\begin{array}{l}\text { Number } \\
\text { of funds }\end{array}$} & \multicolumn{3}{|c|}{$\begin{array}{l}\% \text { of number indicated using } \\
\text { particular investment approach }\end{array}$} & \multirow[b]{2}{*}{$\begin{array}{r}\text { Capital, } \\
\text { USD billion }\end{array}$} & \multicolumn{3}{|c|}{$\begin{array}{l}\% \text { of capital indicated using } \\
\text { particular investment approach }\end{array}$} \\
\hline & & Contrarian & $\begin{array}{r}\text { Trend } \\
\text { follower }\end{array}$ & Fundamental & & Contrarian & $\begin{array}{r}\text { Trend } \\
\text { follower }\end{array}$ & Fundamental \\
\hline Directional & 1,534 & 10 & 13 & 56 & 185.9 & 6 & 10 & 63 \\
\hline Long/Short Equity Hedge & 1,009 & 11 & 3 & 66 & 123.5 & 7 & 2 & 71 \\
\hline Dedicated Short Bias & 18 & 6 & $\ldots$ & 33 & 0.9 & $\ldots$ & $\ldots$ & 71 \\
\hline Global Macro & 131 & 8 & 21 & 51 & 17.8 & 8 & 21 & 73 \\
\hline Emerging Markets & 153 & 5 & 1 & 52 & 22.8 & 2 & $\ldots$ & 52 \\
\hline Managed Futures & 223 & 10 & 61 & 14 & 20.9 & 4 & 62 & 17 \\
\hline Event Driven & 286 & 15 & 1 & 49 & 60.3 & 11 & $\ldots$ & 46 \\
\hline Market Neutral & 452 & 4 & 1 & 35 & 73.7 & 2 & $\ldots$ & 32 \\
\hline Fixed Income Arbitrage & 149 & 1 & 1 & 39 & 32.4 & 1 & $\ldots$ & 34 \\
\hline Convertible Arbitrage & 124 & 5 & $\ldots$ & 24 & 21.9 & 3 & $\ldots$ & 22 \\
\hline Equity Market Neutral & 179 & 4 & 1 & 40 & 19.5 & 2 & $\ldots$ & 38 \\
\hline Other & 116 & 3 & 8 & 35 & 27.6 & 13 & 2 & 44 \\
\hline Fund of Funds & 876 & 16 & 19 & 41 & 115.7 & 12 & 19 & 42 \\
\hline Total (excluding FOHFs) & 2,388 & 9 & 9 & 50 & 347.6 & 7 & 6 & 52 \\
\hline Total & 3,264 & 11 & 11 & 48 & 463.3 & 8 & 9 & 49 \\
\hline
\end{tabular}

Source: TASS database ( 30 June 2005 version).

Note: Only funds with reported (estimated) capital under management.

After a prolonged period of hedge fund underperformance, the risk of a sharp reversal in inflows cannot be discounted. The investor base is probably sufficiently diverse in developed markets, and a reversal of inflows into hedge funds, given their still relatively moderate size, should not have major implications. However, in smaller or less liquid markets, such a scenario could cause temporary liquidity strains, particularly if reversals would occur over a short period.

There are indications that certain strategies (e.g. convertible arbitrage) have reached capacity limits related to market size. If this is indeed the case for most older strategies, then only funds with new ideas or ones dealing in fledgling sophisticated markets can continue to deliver alpha. ${ }^{37}$ According to market reports, the capacity limits of certain strategies or markets has made large and liquid foreign exchange markets attractive to hedge funds once again.

\section{a. Do hedge funds create volatility?}

One question that often arises is whether hedge funds - through their daily activity - stabilise or destabilise financial markets. In this context, two forms of trading can be distinguished: positive and negative feedback trading. The former refers to the buying of financial instruments after price increases and selling after price decreases. This practice can amplify price swings and lead to overshooting or bubbles. Positive feedback or momentum trading can be generated by dynamic hedging, stop-loss orders, similar position-taking by other market participants, forced liquidations related to margin calls or just by simple trendfollowing strategies. By contrast, negative feedback or contrarian trading can have a stabilising influence on markets.

Intuitively, hedge funds should be more contrarian, as only trading against the crowd can be expected to generate persistent excess profits. However, markets are not completely efficient and trend-following can, at times, be

37 Alpha is the return associated with active asset management. It is also referred to as non-systematic risk or specific risk, as opposed to the systemic or overall market risk "beta", which broadly denotes volatility and returns associated with general or market-wide risks (and is also a measure of the volatility relative to the overall market) 
lucrative. Managed futures hedge funds ( $5 \%$ of the total single hedge fund capital under management, see Chart 20) are reportedly cited as utilising trend-following approaches (see Table 15). However, researchers from the US Commodity Futures Trading Commission (CFTC), using micro trading data, have found that managed futures hedge funds can dampen rather than increase volatility in energy markets by providing liquidity to other market participants. ${ }^{38}$ Other directional strategies global macro $(10 \%)^{39}$, emerging markets $(4 \%)$, long/short equity $(32 \%)$ - can be on both sides of the spectrum, while dedicated short-sellers (less than $1 \%$ ) are probably more contrarians. According to TASS data, global macro funds also seem to employ rather extensively trendfollowing approaches, but at the same time they rely more on fundamental analysis. Event driven (19\%) and market neutral (19\%) strategies probably also involve the taking of more contrarian views. Hence, it is very difficult to determine whether hedge funds, on average, are momentum traders or contrarians.

\section{b. Do hedge funds benefit from volatility?}

Conventional wisdom suggests that hedge funds thrive in volatile financial markets. This is frequently put forward as a reason for the diminishing returns that were observed in the rather low stock market volatility environment in the second quarter of 2004. However, there is no conclusive evidence on this issue. Indeed, contrary to popular belief, calculations indicate that over the past 11 years hedge funds, on average, tended to perform better when stock markets were less volatile (see Chart 42 and Chart 43).

The correlation coefficients between the annualised S\&P 500, Dow Jones EURO STOXX historical monthly volatility and the CSFB/Tremont Hedge Fund Index monthly returns were negative..$^{40}$ In other words, higher volatility was associated with lower hedge fund returns. The results are similar across almost all hedge fund strategies. Only dedicated short-sellers and managed futures funds, which together account for only around
$5 \%$ of total capital under management, tend to perform better in volatile markets. Thus, although short-sellers are more likely to be contrarians, their returns tend to be higher in volatile markets, as volatility is usually higher in falling rather than rising markets. These results suggest that many hedge funds could actually be short in volatility owing to the nature of their strategies.

Another plausible explanation as to why lower volatility could benefit hedge fund performance is related to the impact of leverage. For example, a price decrease of $5 \%$ on a five times leveraged investment portfolio means a $25 \%$ loss for capital under management. Hence, larger price declines may force hedge funds to unwind losing leveraged positions more often due to internal risk limits or margin calls from prime brokers. In addition, by selling into a falling market, hedge funds may also further exacerbate volatility, especially if the relative size of their positions or activity is significant for the affected markets. The lower the available liquidity buffers are and the higher the use of leverage is, the more often hedge funds will be forced to liquidate positions. ${ }^{41}$ However, hedge funds probably do not use all available leveraging possibilities and have some capital cushion in times of stress. In the TASS database, about one-third of single hedge funds provide information on average and maximum leverage (as specified in offering documents or voluntarily set by managers). ${ }^{42}$ Of those, about $10 \%$ have a ratio of average to maximum leverage in excess of 0.9 .

38 Haigh et al. (2005).

39 For example, Tiger Fund, a prominent global macro hedge fund, was betting against the technology bubble, but its capital was depleted and investors withdrew before the bubble actually burst.

40 In both cases pairwise correlation coefficients are statistically significant (i.e. different from zero) at a $99 \%$ confidence level (132 observation pairs).

41 See the discussion about the implications of hedge fund leverage on credit markets by Fitch Ratings (2005).

42 Including only cases where the provided average or maximum leverage is not zero and average leverage is not higher than maximum leverage. 


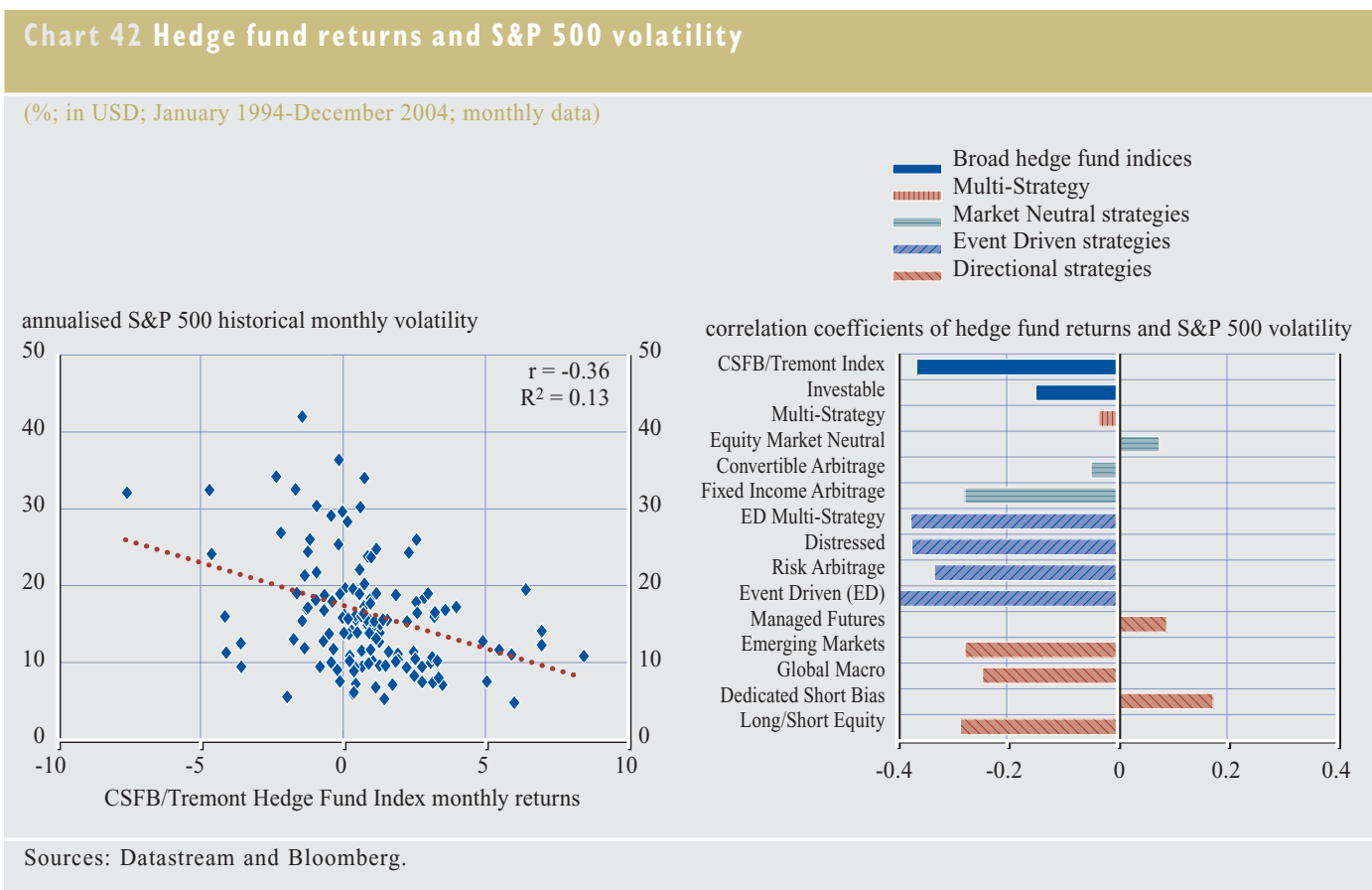

\section{Chart 43 Hedge fund returns and DJ EURO STOXX volatility}

(\%; in USD; January 1994-December 2004; monthly data)

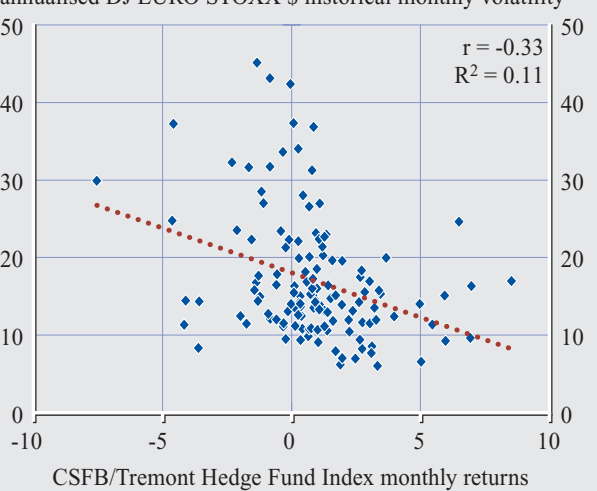

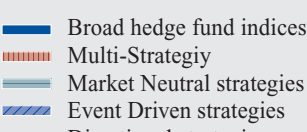

2III) Event Driven strategies

IIIv Directional strategies

correlation coefficients of hedge fund returns and DJ EURO STOXX \$ volatility CSFB/Tremont Index $\mathrm{CSFB} /$ Tremont Index
Investable Investable
Multi-Strategy Equity Market Neutral Convertible Arbitrage Fixed Income Arbitrage ED Multi-Strategy Distressed Distressed
Risk Arbitrage Risk Arbitrage
Event Driven (ED) Managed Futures Emerging Markets Global Macro Dedicated Short Bias Long/Short Equity

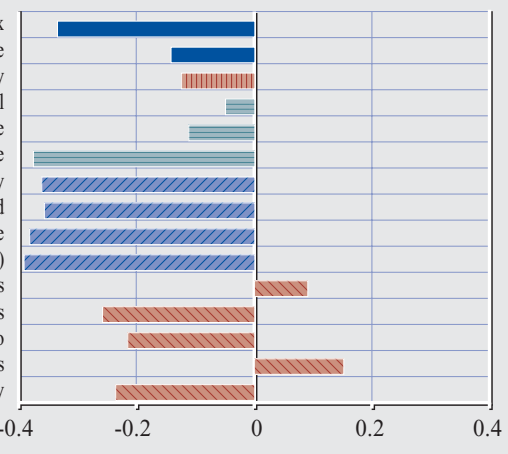

Sources: Datastream and Bloomberg.

c. The issue of "crowded trades"

As an increasing number of funds attempt to exploit profitable opportunities from similar strategies, concerns have been raised that the positioning of individual hedge funds is becoming more similar or "crowded". Moreover, the growth of the industry could also be leading to diminishing returns and could, as a result, push funds into greater risk-taking, through increased leverage. This sub-section 


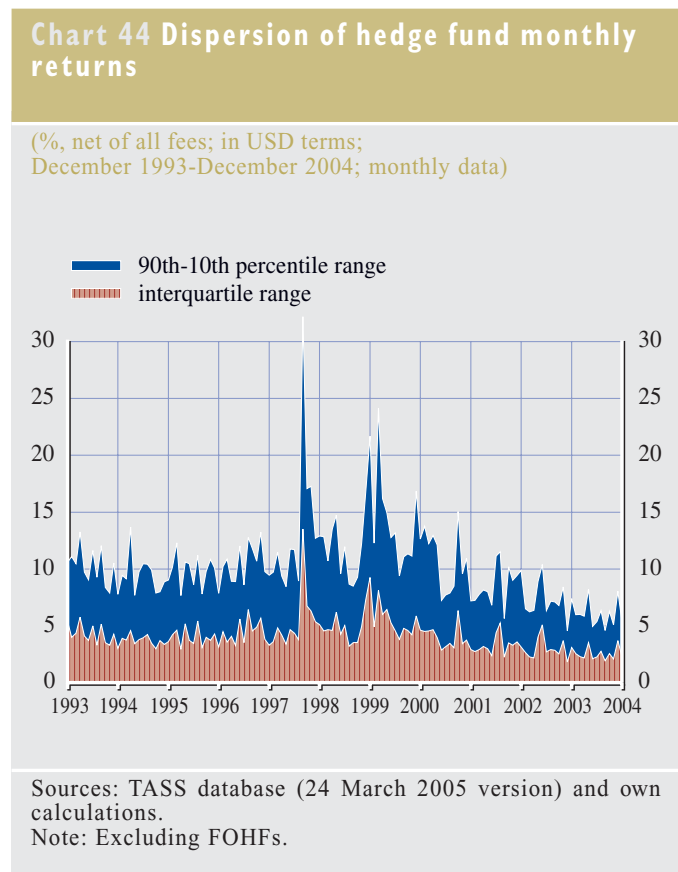

examines the issue of the risk that crowded trades could result in adverse market dynamics by analysing recent hedge fund return performances from a historical perspective.

When markets are stable, the presence of hedge funds can boost liquidity, whereas under stressed conditions hedge funds - because they are unlikely or simply cannot afford to wait when leveraged positions begin to lose money - would probably be among the first to "rush for the exit". The crowding of trades or similar positioning across hedge funds within a particular strategy may further magnify the impact of hedge fund exits on certain fledgling or "exotic" markets where the involvement of regulated institutional investors is less prevalent. ${ }^{43}$

Since 2001, hedge fund returns have become less widely dispersed (see Chart 44), which could be a broad indication that hedge fund positioning is becoming increasingly similar, although it might also be related to the relatively more benign market environment or to lower risk-taking by hedge funds. One way of disentangling this is to consider patterns in pairwise correlation coefficients of individual

\section{Chart 45 Distribution of pairwise}

correlation coefficients of monthly hedge

fund returns within each strategy

6 FINANCIAL

STABILITY

IMPLICATIONS

hedge fund return performance within strategies. Rising correlations could be a sign that hedge fund managers are employing models that are too similar and are no longer creating true alpha - or excess returns - that are uncorrelated with other managers within the same strategy, even though they may still outperform other types of investments. If correlations are high, hedge funds within a strategy may be more likely to liquidate positions simultaneously in the event of a serious market shock, thus amplifying price swings or even causing liquidity to dry up. Higher correlations also imply reduced diversification possibilities for funds of hedge funds specialising in a particular strategy.

The median pairwise correlation coefficients of hedge fund monthly returns within each strategy for the 11 years between December 1993 and December 2004 are generally not very

43 The positions of investment banks also matter as their proprietary trading desks sometimes use similar strategies or enter into "copycat" trades, based on the assumption that hedge funds have superior market knowledge. 
Chart 46 Medians of pairwise correlation coefficients of monthly hedge fund returns within strategies

(moving 12-month window; December 1994-December 2004; monthly data)

Convertible Arbitrage (6\%)

-.... Fixed Income Arbitrage (7\%)

- - - Equity Market Neutral (5\%)

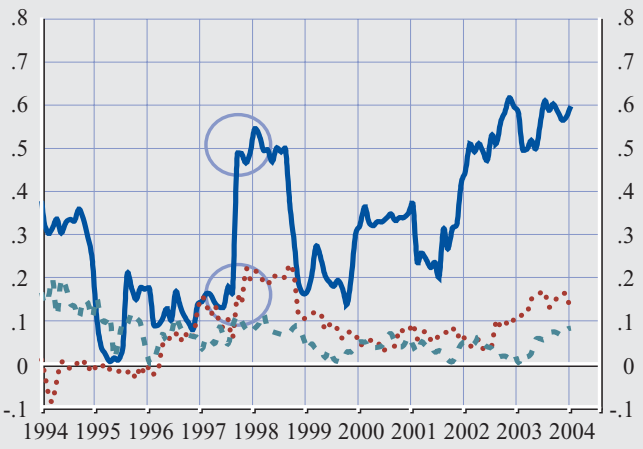

- Fund of Funds

.... Event Driven $(19 \%)$

- - - Other (Multi-Strategy) (10\%)

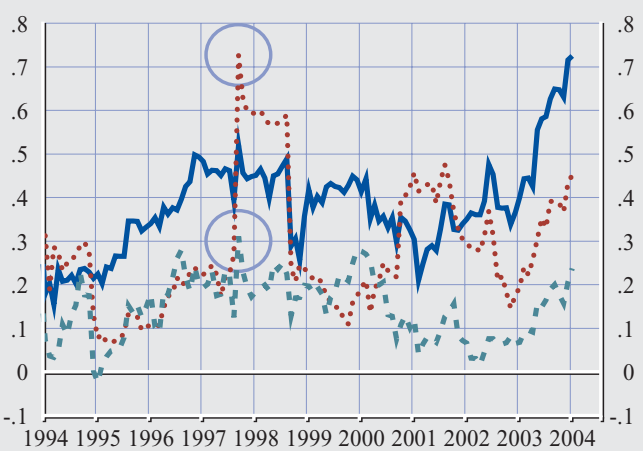

Dedicated Short Bias $(0 \%)$

.... Managed Futures $(5 \%)$

- - - Long/Short Equity Hedge (32\%)

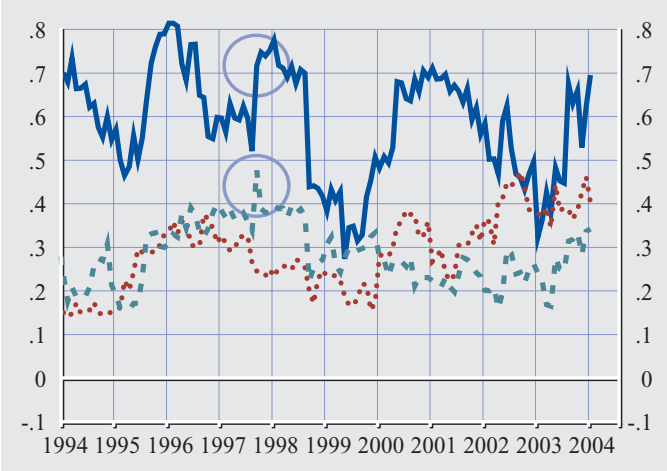

Sources: TASS database (24 March 2005 version), TASS Research and own calculations.

Notes: Circled points refer to August 1998. For each 12month moving window, only hedge funds with 12 monthly observations were included. Numbers in parentheses after observations were included. Numbers in parentheses after strategy names indicate the share of total capital under high (see the left panel of Chart 45). ${ }^{44}$ After taking into account slightly different classifications of strategies, the values roughly correspond to those obtained by the FSF in 2000 from the MAR/Hedge database for the period from January 1990 to August 1999.45 According to both calculations, short-sellers and funds of funds were the two categories with the highest medians. Based on the more recent 11-year TASS sample, two market neutral strategies, namely fixed income arbitrage and equity market neutral, had the lowest pairwise correlation coefficients, whereas the convertible arbitrage strategy ranked third, ahead of event driven and other directional strategies.

However, these results cover rather long periods, while the medians of pairwise correlation coefficients of returns over the 12 months to December 2004 convey a more worrying picture (see the middle and righthand panels of Chart 45). ${ }^{46}$ Across all strategies, medians were substantially higher and the distributions of pairwise correlation coefficients were more negatively skewed than their long-term values. For many strategies the proportions of pairwise correlation coefficients close to or less than zero were substantial. This suggests that in 2004 there were still hedge funds with returns that were uncorrelated to other hedge funds within the same strategy, assuming funds were (self-) classified correctly and that there was no style drift.

In normal times, similar actions by hedge funds may lead to varied performances, even if hedge

44 In the TASS database, some time series of hedge fund returns represent merely counterpart onshore and offshore funds or different classes of shares with different fee structures, lockup periods and other "technical" differences. As a result, such time series basically correspond to the parts of the same pool of money, which are managed in a highly correlated or nearly identical way. Therefore, to ensure conservative results, such time series were aggregated by taking averages of returns weighted by capital under management.

45 Financial Stability Forum (2000), p. 89 and p. 104

46 Given 12 observation pairs and a 5\% (1\%) confidence level, statistically significant (i.e. different from zero) module values of pairwise correlation coefficients should exceed $0.58(0.71)$. 
fund investment strategies, positions and expectations within strategies might be very alike. This is likely to be the case because of a sufficient diversity in micro factors, such as portfolio structure, liquidity profile, internal risk limits or timing. However, under stressed conditions, these differences tend to disappear, especially if trades are leveraged, and the ability of hedge funds to take offsetting contrarian positions is limited.

In times of stress, if trades are crowded, the correlations of return performances can surge. This occurred in August and September 1998 after the Russian default and the near-collapse of LTCM (see Chart 46). Putting the recent rise of correlations into this historical context, the behaviour of median pairwise correlation coefficients within funds of funds, eventdriven, convertible arbitrage and managed futures strategies in a relatively benign market environment raises concerns. The medians of convertible arbitrage, fixed income arbitrage, event-driven and managed futures strategies have also exhibited long-term rising trends.

All in all, there are indications that hedge fund positioning has resulted in a crowding of trades in some markets, possibly leaving them vulnerable to adverse market dynamics. These concerns are the greatest for convertible arbitrage and credit strategies, where close monitoring is called for, especially as these strategies generally have the highest leverage and therefore significant gross positions. The unwinding of these positions could prove disruptive for the fixed income markets in which these funds are involved, especially if the degree of liquidity in these markets was to prove low. ${ }^{47}$

\section{REGULATORY AND SUPERVISORY IMPLICATIONS}

\section{I RISK MANAGEMENT PRACTICES}

Since the near-default of LTCM, several public and private initiatives have been launched to address some of the concerns raised by hedge funds. Annex B provides a selected overview of such initiatives, some of which are aimed at improving risk management practices at the counterparties of hedge funds. The underlying rationale of this approach is that such indirect regulation is probably more effective than the direct regulation of hedge funds, which can move their domicile quite easily from one country to another and therefore can easily engage in regulatory arbitrage. In addition, the hedge fund industry itself has taken several initiatives to develop (non-legally binding) sound practices with the aim of enhancing investor protection and market soundness. ${ }^{48}$

The work of the $\mathrm{BCBS}^{49}$ is the most prominent of the public sector initiatives. In 1999, the BCBS issued a list of sound practices for banks' interactions with "highly leveraged institutions" (HLIs). ${ }^{50}$ These practices were designed to address some of the major risk management failures that emerged from the LTCM episode, i.e. over-reliance on the collateralisation of mark-to-market exposures, and the insufficient weight placed on the in-depth credit analyses of HLIs. The sound practices specifically addressed areas such as policies and procedures for banks' interaction with HLIs, information gathering and credit analysis of HLIs, exposure measures and the monitoring of such exposures, credit limits, and the link between credit enhancement tools (such as collateral) and the specific characteristics of HLIs.

In a follow-up report, the BCBS concluded that although banks had improved their risk management practices, there were still a number of areas that required sustained attention, most notably the due diligence

47 A breakdown is not available, but a subset of hedge funds in the event driven strategy specialise in distressed/high yield debt, which is also rather illiquid.

48 See, for example, the Managed Funds Association (2005) and Alternative Investment Management Association (2002).

49 In addition, IOSCO took several initiatives; see for example International Organization of Securities Commissions (1999).

50 Basel Committee on Banking Supervision (1999b).
7 REGULATORY AND SUPERVISORY IMPLICATIONS 
process for establishing credit relations with HLIs, the development of improved exposure measures, and the use of stress-testing. ${ }^{51}$ These conclusions were basically confirmed in a joint report published by the BCBS and IOSCO a year later. ${ }^{52}$

Significant private sector initiatives include those of the Counterparty Risk Management Policy Group (CRMPG), the International Swaps and Derivatives Association (ISDA) and the Institute of International Finance (IIF). The CRMPG or "Corrigan group" is a group of 12 major, internationally active banks and securities firms that have developed standards for strengthened risk management practices for financial firms that provide credit in the derivatives and securities markets. ${ }^{53}$ These improved standards are based on the following broad principles: (i) enhanced informationsharing between counterparties, (ii) an integrated framework to assess market risk, liquidity risk and leverage, (iii) stress-testing and liquidation-based estimates of counterparty credit exposures, (iv) the need to take into account potential liquidation costs in setting limits and collateral standards, (v) enhancements in the quality of information, and (vi) improvements in the standards of industry documentation. The CRMPG recently published a review of its guidance, taking into account the financial, regulatory and supervisory developments that have occurred since 1999. The Group also investigated in detail complex financial products, including hedge funds, and their implications for risk management. ${ }^{54}$

Following up on the market events of the 1990s, the ISDA reviewed its collateral management practices, which led to 22 recommendations for enhancements. ${ }^{55}$ The recommendations cover areas such as: (i) the relationship between collateralisation and credit analysis, (ii) the management of risks related to collateralisation, (iii) dispute resolution, (iv) the length of the collateral cycle, (v) the range of collateral accepted, (vi) margining, (vii) legal and documentation issues, (viii) cross-product netting, and (ix) substitution of collateral. Finally, the IIF, a global association of financial institutions, also published in 1999 a number of recommendations in the area of risk management. ${ }^{56}$

\subsection{DISCLOSURE, TRANSPARENCY AND THE VALUATION OF POSITIONS}

The international supervisory and central banking community has become increasingly convinced that market discipline can play an important role in maintaining financial stability. A precondition for market discipline to be effective is adequate public disclosure about the risks that financial intermediaries can incur. Following the market events of the 1990s, several international initiatives were launched to improve disclosure by regulated as well as unregulated (such as hedge funds) intermediaries.

The so-called "Fisher II" working group" (2001) recommended that financial intermediaries, including hedge funds, should periodically disclose, when risks are material, quantitative information related to market risk in trading activity, firm-wide exposure to market risk, funding liquidity risk, credit risk and insurance risk. To the extent that not all hedge funds disclose this information on a voluntary basis, the group recommended that the relevant authorities should consider requiring this disclosure. The group also concluded that the indicated information should be considered to be a minimum of what would be expected in bilateral disclosures to

51 Basel Committee on Banking Supervision (2000)

52 Basel Committee on Banking Supervision and the International Organization of Securities Commissions (2001)

53 Counterparty Risk Management Policy Group (1999).

54 Counterparty Risk Management Group (2005).

55 International Swaps and Derivatives Association (1999). 56 Institute of International Finance (1999).

57 Multidisciplinary Working Group on Enhanced Disclosure (2001). This Working Group was jointly sponsored by the BCBS, the Committee on the Global Financial System (CGFS), the International Association of Insurance Supervisors (IAIS) and IOSCO. 
judge the adequacy of regulated firms' risk management capabilities.

As a follow-up to the recommendations, the Joint Forum ${ }^{58}$ established a working group to assess the extent to which the recommendations had been adopted. ${ }^{59}$ However, regarding hedge funds, the working group was unable to obtain the necessary information to provide a meaningful basis for further review. This was attributed to possible concerns about client confidentiality, the proprietary nature of the funds' positions, and a general reluctance to engage in a dialogue with the regulatory community. The working group did not draw any conclusions from these findings regarding the regulation of hedge funds.

Inadequate disclosure and transparency are to a very large extent rooted in the largely unregulated nature of hedge funds. Moreover, problems related to the valuation of positions are often the direct cause of hedge fund failures. ${ }^{60}$ Apart from the limited regulatory and auditing standards that apply to hedge funds, other factors that explain this type of operational risk are the investment strategies pursued by the funds (positions for which there might be no readily available market prices), the small size of the hedge fund enterprise (with less scope for rigorous segregation of functions), and performance-related fees (which create an incentive for managers to misrepresent asset values). Another complicating factor with regard to enhancing disclosure for hedge funds is that no generally accepted market standard has yet emerged that can adequately measure leverage ${ }^{61}$, which is crucial in assessing the level of risk faced by a hedge fund.

The effect of strong institutional demand for hedge funds on transparency is ambiguous. On the one hand, it reduces incentives for hedge funds to be more transparent, yet, on the other hand, hedge funds are forced to disclose more information in order to attract funds. The outcome ultimately depends on the relative negotiating strength of the two parties involved. There are some indications that, over the last years, transparency has improved for direct investors and prime brokers, but not for other market participants. Some authors are also sceptical about the positive financial stability effects of enhanced disclosure, stressing that it might negatively impact on the liquidity of financial markets. ${ }^{62}$

\subsection{SOUND BUSINESS PRACTICES}

With the growth in the hedge fund business, the number of hedge fund-related fraud cases has also increased. As discussed in the previous sub-section, the largely unregulated nature of the business makes it particularly vulnerable to misrepresentation and fraud. In its recent proposed rule regarding the registration of certain hedge fund advisors, the Securities and Exchange Commission (SEC) estimated that in the past five years it had acted against hedge fund fraud totalling more than USD 1 billion. The SEC's cases included the gross overstatement of hedge fund performance, the payment of unnecessary and undisclosed commissions, and the misappropriation of client assets by hedge funds. Advisers to hedge funds were also key participants in the recent scandals involving mutual fund late trading and inappropriate market timing. ${ }^{63}$ Since the management of hedge funds is very international in nature, it has been argued that the hedge fund business is particularly vulnerable to money laundering attempts. Hedge fund managers should therefore duly verify, directly or indirectly (e.g. through the fund's administrators), the identity of the investors in their funds.

58 The Joint Forum is an international group of technical experts working under the umbrella of the BCBS, the IAIS and IOSCO.

59 Joint Forum (2004).

60 See for example, Kundro and Feffer (2004).

61 Multidisciplinary Working Group on Enhanced Disclosure (2001). This was one of the areas which the working group identified where the industry could do further work.

62 Persaud (2001).

63 Securities and Exchange Commission (2004).
7 REGULATORY AND SUPERVISORY IMPLICATIONS 


\subsection{REGULATORY ISSUES}

In the United States, the SEC ruled at the end of 2004 that most hedge fund advisors (i.e. managers) must register with the SEC and comply with the regulations that apply to other registered investment advisors. This requirement was introduced by changing the rule that an investment advisor was exempted from registration if, among other things, he or she advised no more than 14 clients. Under the new rules, an advisor to a private (hedge) fund is no longer permitted to count the fund, rather than its owners, as a single client (the "look through" approach). The registration implies the need to keep written records, and that there will be heightened scrutiny of conflicts of interest and their disclosure, plus the possibility of SEC inspections, etc. Advisors should register before 1 February 2006. The rule followed an extensive investigation by the SEC into the implications of the growth of hedge funds. This investigation identified a number of concerns, including a lack of information regarding unregistered advisors, which made it difficult to uncover fraud, and the way in which advisors value hedge fund assets. ${ }^{64}$ The decision was by no means uncontroversial - indeed, the SEC commissioners were themselves divided on the issue $^{65}$, and a number of industry groupings have already indicated that they plan to challenge the SEC decision before the courts. ${ }^{66}$

At present, there is no common regulatory regime in the EU for hedge funds or their managers. ${ }^{67}$ At the same time, it should be recalled that, on a global basis, the great majority of hedge funds continue to be managed by US managers, although the importance of managers located in the EU is steadily increasing (see Chart 5 and Chart 7). Because of their investment strategies, hedge funds typically fall outside the scope of the UCITS Directives. ${ }^{68}$ One implication of this is that they do not benefit from having a "European passport", which prevents their marketing across the EU. Their EU investment managers, by contrast, are already subject to the Financial Instruments and Markets Directive $^{69}$, which recently replaced the Investment Services Directive.$^{70}$ Hence, hedge funds in the EU are often set up where they are distributed, although there is an increasing use of pan-European domiciles.

In January 2004, the European Parliament adopted a resolution on hedge funds based on a report by its Economic and Monetary Affairs Committee (EMAC). ${ }^{71}$ In this resolution, the Parliament proposed to introduce a light regulatory regime for "sophisticated alternative investment vehicles", which include hedge funds. The purpose of this proposal would be to bring onshore funds that are presently offshore and to provide them with the benefit of a European passport. The industry was also invited to develop a selfregulatory code of conduct.

Following the near-completion of the Financial Services Action Plan (FSAP), the European Commission set up four expert groups of market practitioners to assess the state of integration of European financial markets. In its May 2004 report, the asset management expert group recommended inter alia that the Commission should review the EU regulatory framework to allow currently non-harmonised products, such as hedge funds, to be brought to the market on an EU-wide basis, subject to appropriate safeguards. Current UCITS legislation could be used as a reference for this regulation, but adapted to the specific nature of the products.

For the time being, the European Commission and the Council have not yet taken up the

64 Securities and Exchange Commission (2003).

65 See Atkins (2004) for some of the arguments against the ruling.

66 Avery (2005), Maiden (2004)

67 An overview of the regulation of hedge funds in Europe can be found in PricewaterhouseCoopers (2003 and 2004b).

68 See in particular the Directives 85/611/EEC, 2001/108/EC and $2001 / 017 / \mathrm{EC}$

69 Directive 2004/39/EC

70 Directive 93/22/EEC.

71 European Parliament (2003). 
Parliament's proposal and the recommendations of the asset management group. In its recently released Green Paper for financial services policy in the next five years $^{72}$, the Commission did not signal any particular initiatives planned in the area of hedge funds. This was confirmed in the Green Paper on asset management ${ }^{73}$ published a few months later in which it was stated that there was currently no compelling evidence for EU legislation. Nevertheless, the Commission confirmed that some issues deserved further attention, including the growing access to retail investors, the exposures of investment banks and the impact on financial markets. In that respect, it invited responses from the public to these issues and also announced the creation of an industry working group on alternative investment strategies.

The domestic regulation of hedge funds takes place at three levels: (i) the fund manager, (ii) the fund itself, and (iii) the distribution of the fund. Table 16 provides a brief overview of the situation in a selected number of European countries for a number of key elements for each of these three levels.

In most European countries, traditional fund managers are also allowed to manage domestically and/or offshore domiciled hedge funds. For example, in the United Kingdom the FSA applies a regulatory regime to hedge fund managers that is similar to the one that applies to other investment managers. Following an industry consultation that took place last year, the FSA has confirmed that it has no intention of introducing a special regime to regulate hedge fund managers, since the present regime was generally deemed to be appropriate. ${ }^{74}$ This position is particularly relevant for the EU hedge fund industry, since the majority of EU hedge funds are managed from London. More recently, however, hedge fund managers have also started to emerge in countries such as France, Ireland, Italy and Sweden.

Most hedge funds are domiciled offshore because of the prevailing lighter regulatory regime and for tax reasons. ${ }^{75}$ However, some European jurisdictions, such as France, Ireland, Italy, Luxembourg and Sweden, have also tried to attract hedge fund business by providing a flexible regime. Ireland is particularly attractive as a domicile for EU hedge funds, where they are often listed on the stock exchange. Similarly, Luxembourg has taken a number of measures to attract the hedge fund business and is increasingly seen as an alternative to Ireland. Reasons behind choosing a European location in spite of the advantages offered by going offshore might be to target investors that have a preference for EU funds or that are legally restricted to investing outside the EU. European locations might also benefit from the international initiatives against some offshore financial centres that are accused of engaging in harmful tax competition or that are deemed not to comply with the international standards to prevent money laundering. ${ }^{76}$

Finally, with regard to the distribution of hedge funds, they are traditionally targeted at high net worth individuals or institutional investors so that they do not fall under the protection regime in place for retail investors. Sometimes, retail investors have gained indirect access to hedge funds via so-called wrappers, which are financial products (such as structured notes, unit-linked insurance policies) whose performance is linked to that of an underlying hedge fund or a portfolio of hedge funds.

There is a trend towards the "retailisation" of hedge funds, and several European countries have recently permitted the distribution of hedge funds to retail investors, even though, compared to the traditional funds industry, retail investments in (funds of) hedge funds are

\footnotetext{
72 European Commission (2005a)

73 European Commission (2005b)

74 UK's Financial Services Authority (2003).

75 Popular European offshore centres for hedge funds are Jersey, Guernsey and the Isle of Man.

76 See in this respect, for example, the different initiatives launched by the FSF, the Organisation for Economic Cooperation and Development (OECD) and the Financial Action Task Force (FATF).
}

7 REGULATORY AND SUPERVISORY IMPLICATIONS 
still very small. Allowing hedge fund products to be distributed to retail investors raises specific investor protection concerns, such as inadequate disclosure, the risk of mis-buying and mis-selling, the lack of sufficient diversification, disproportionate management costs, etc. ${ }^{77}$ Some of these concerns can be addressed by only allowing certain variants of hedge funds to be commercialised, such as FOHFs or funds with capital protection.
From its earlier mentioned consultation, the United Kingdom's FSA concluded that there was no great desire on the part of the industry to produce and sell retail hedge fund products. However, more recently the FSA has indicated that it might re-examine the prohibition to sell

77 See also International Organization of Securities Commissions (2003).

\begin{tabular}{|c|c|c|c|c|c|c|}
\hline \multicolumn{7}{|c|}{$\begin{array}{l}\text { Table I } 6 \text { The regula } \\
\text { number of EU Memb } \\
\text { (situation as of May 2003) }\end{array}$} \\
\hline & \multicolumn{2}{|c|}{ Hedge fund managers } & \multicolumn{2}{|c|}{$\begin{array}{l}\text { Existence of domestic } \\
\text { domiciled hedge funds }\end{array}$} & \multicolumn{2}{|c|}{ Distribution of hedge funds } \\
\hline & Regulator & Minimum capital requirement & Single fund? & FOHF? & Main channel & $\begin{array}{l}\text { FOHFs } \\
\text { available } \\
\text { to public? }\end{array}$ \\
\hline AT & FMA & Varies & & & $\begin{array}{l}\text { Banks, wrappers, fund } \\
\text { distribution companies }\end{array}$ & Yes \\
\hline $\mathrm{BE}$ & Not regulated & Not regulated & & & $\begin{array}{l}\text { Banks, private placements, } \\
\text { wrappers }\end{array}$ & \\
\hline $\mathrm{DE}$ & Not regulated & Not regulated & Yes & Yes & Banks & Yes \\
\hline DK & Danish FSA & N/A & & & Uncommon & \\
\hline ES & CNMV & $\begin{array}{l}€ 300,000 \text { and own funds } \\
\text { requirement, which varies } \\
\text { depending on assets under } \\
\text { management }\end{array}$ & & & Issuers of structured notes & \\
\hline FI & Finnish FSA & $€ 169,000$ & Yes & Yes & $\begin{array}{l}\text { Direct sales via } \\
\text { management company }\end{array}$ & Yes \\
\hline FR & $\mathrm{COB}$ & $\begin{array}{l}25 \text { of operating expenses } \\
\text { with a minimum of } \\
€ 50,000\end{array}$ & & Yes & Wrappers & Yes \\
\hline IE & IFSRA & $\begin{array}{l}\text { Usually } € 50,000 \\
\text { initial capital }+3 \text { months } \\
\text { of annualised expenditure }\end{array}$ & Yes & Yes & Private banks, brokers & Yes \\
\hline IT & $\begin{array}{l}\text { Bank of Italy; } \\
\text { CONSOB }\end{array}$ & $€ 1,000,000$ & Yes & Yes & Private placements & Yes \\
\hline LU & CSSF & $\begin{array}{l}€ 125,000 \\
\text { (type } 2 \text { managers), } \\
€ 1,500,000 \\
\text { (type } 3 \text { managers) }\end{array}$ & Yes & Yes & $\begin{array}{l}\text { Private banks, } \\
\text { universal banks }\end{array}$ & Yes \\
\hline NL & Netherlands AFM & $€ 226,890$ & Yes & Yes & $\begin{array}{l}\text { Direct sales, brokers, } \\
\text { issuers of structured notes }\end{array}$ & Yes \\
\hline PT & CMVM & $€ 250,000$ & & & Uncommon & \\
\hline SE & Swedish FSA & SEK $1,000,000$ & Yes & Yes & Direct sales on private basis & \\
\hline UK & UK's FSA & $\begin{array}{l}\text { Usually } € 50,000 \\
\text { own funds + liquid capital } \\
\text { of three months' annualised } \\
\text { expenditure }\end{array}$ & & & $\begin{array}{l}\text { Independent financial } \\
\text { advisors, wrappers }\end{array}$ & \\
\hline
\end{tabular}


hedge funds to retail investors. ${ }^{78}$ Germany, by contrast, adopted at the end of 2003 a new investment act that implemented a new legal framework for domestic hedge funds and the marketing of foreign funds in Germany. ${ }^{79}$ The new act explicitly distinguishes between single hedge funds and FOHFs. The former are hardly subject to any investment restrictions at all ${ }^{80}$, whereas the latter are subject to more stringent restrictions, since they are the only hedge funds that can be distributed by public offer. For example, the latter are not allowed using leverage or short-selling, can only invest in single hedge funds, and are subject to certain diversification requirements.

\section{CONCLUSIONS}

The near-default of LTCM proved to be only a temporary setback to the development of the global hedge fund industry, which has since continued to grow strongly. However, the increasing proliferation of hedge funds as an alternative investment for both institutional and retail investors raises questions about the wider financial stability implications of this form of financial intermediation.

Although hedge funds are very much associated with the negative events of the LTCM period, it is important to understand that they have various positive effects on the financial system: they contribute to market liquidity, play an important role in the price discovery process, contribute to the elimination of market inefficiencies, and offer diversification benefits to investors. Moreover, their activities have probably contributed to the integration of financial markets.

The potential threat that hedge funds pose to the financial system comes via their impact on credit institutions or financial markets. The direct exposures of credit institutions to hedge funds are mainly the result of their role as prime broker. In this capacity they provide leverage, issue credit lines and incur trading exposures. Data seem to indicate that the prime brokerage business is highly concentrated among a limited set of important global market players. This business also seems to have become increasingly competitive over time, with a number of second-tier players aggressively trying to gain market share.

Since the end of the 1990s, considerable progress has been made by both the public and the private sector in the further development of risk management standards that are designed to address some of the concerns related to exposures on hedge funds. However, in a highly competitive field it is also important that these risk management standards are effectively applied and not eroded. In this respect, banking supervisors are expected to follow up on the earlier recommendations of the BCBS, possibly also in cooperation with securities and insurance supervisors.

The indirect links between credit institutions and hedge funds are more difficult to gauge, but may be significant. Market data, such as VaR figures, for example, show that a number of large credit institutions (including European ones) have taken on more market risk and are engaging in hedge fund-like strategies. Under these conditions, negative market events may not only have an impact on the direct relationship between credit institutions and hedge funds (for example, through credit, trading, investment or revenue exposures), but may also simultaneously affect the proprietary market positions of credit institutions.

It is very difficult to provide any conclusive evidence on the impact of hedge funds on financial markets, which is at least partially due to the lack of good data. However, the available information points to a situation which is probably more positive than before the

78 Sants (2004); see also UK's Financial Services Authority (2005a).

79 On the new legal framework in Germany, see for example Pütz and Schmies (2004).

80 Interestingly, however, the Minister of Finance has the power to restrict the use of leverage and short sales to prevent abuse or to protect the integrity of financial markets. 
LTCM crisis, for three main reasons. First, banks use more sophisticated techniques to manage their exposures to hedge funds, although new challenges are emerging that need continuous monitoring. Second, as more players have entered the market, positions are probably much less concentrated in one or a few funds. Third, in general it seems that the leverage levels taken on by funds are now lower. There is the risk, however, that as more money flows into hedge funds and the profit opportunities diminish commensurately, some players might take on more risk or leverage to achieve targeted returns. Moreover, there is some evidence that hedge funds engage in "crowded trades", i.e. take similar positions, which could lead to market disturbance in case of simultaneous exits in the event of a market shock.

In addition to the need to monitor whether risk management practices and techniques are sufficient for the risks involved, the most important challenge for public authorities seems to be to increase their knowledge about the impact of hedge funds on the financial system, both through credit institutions and financial markets. To a large extent, such an assessment depends on good quality information - yet high-quality information tends to be difficult to obtain, as hedge funds themselves have not increased their disclosure and transparency to the degree that authorities had hoped. It is therefore important to continue to exercise pressure, for example through the relationship between hedge funds and regulated firms, to ensure further improvements in this area. At the same time, the dialogue of public authorities with the asset management industry needs to be continued and enhanced to improve further market practices by hedge funds.

Whether or not there is a need to regulate hedge funds from an investor protection point of view is not clear-cut. On the one hand, there are indications that hedge funds are becoming increasingly available to retail investors. On the other hand, the amount of retail investments is still very limited compared to the traditional funds. From a European perspective, it might therefore be worthwhile first investigating more closely whether, and in what form, significant "retailisation" is indeed taking place in the EU ${ }^{81}$ At the same time, if there are indeed important financial stability concerns to be addressed - primarily via enhanced transparency and disclosure - this can only be done effectively in a strongly coordinated manner at the international (transatlantic) level. ${ }^{82}$
81 At the international level, IOSCO is reportedly presently conducting a stocktaking of regulatory regimes, addressing the access of retail investors to hedge funds. See UK's Financial Services Authority (2005a). 82 Trichet (2005). 
A N NEXES 


\section{ANNEX A}

\section{EVOLUTION OF THE HEDGE FUND INDUSTRY}

\section{Table AI Number of hedge funds}

\begin{tabular}{|c|c|c|c|c|c|c|c|c|}
\hline Strategy, as a $\%$ of total & 1990 & 1991 & 1992 & 1993 & 1994 & 1995 & 1996 & 1997 \\
\hline Directional & 60 & 61 & 60 & 61 & 60 & 59 & 58 & 58 \\
\hline Long/Short Equity Hedge & 24 & 24 & 24 & 24 & 23 & 25 & 28 & 29 \\
\hline Dedicated Short Bias & 2 & 2 & 2 & 2 & 1 & 1 & 1 & 1 \\
\hline Global Macro & 6 & 8 & 8 & 6 & 6 & 6 & 5 & 5 \\
\hline Emerging Markets & 3 & 4 & 5 & 6 & 7 & 8 & 8 & 9 \\
\hline Managed Futures & 23 & 23 & 22 & 23 & 22 & 19 & 16 & 14 \\
\hline Event Driven & 10 & 10 & 8 & 8 & 8 & 8 & 9 & 9 \\
\hline Market Neutral & 6 & 6 & 8 & 8 & 9 & 10 & 10 & 11 \\
\hline Fixed Income Arbitrage & 1 & 1 & 2 & 3 & 4 & 3 & 4 & 4 \\
\hline Convertible Arbitrage & 3 & 3 & 4 & 3 & 4 & 4 & 3 & 3 \\
\hline Equity Market Neutral & 2 & 2 & 2 & 2 & 2 & 2 & 3 & 3 \\
\hline Other & 1 & 1 & 1 & 2 & 2 & 2 & 3 & 3 \\
\hline Fund of Funds & 23 & 22 & 23 & 21 & 21 & 21 & 20 & 19 \\
\hline \multicolumn{9}{|l|}{ Size, as a $\%$ of total } \\
\hline$\leq \$ 100 \mathrm{~m}$ & 91 & 89 & 89 & 87 & 88 & 90 & 88 & 85 \\
\hline$\$ 100 m-\$ 1 b n$ & 9 & 11 & 10 & 13 & 11 & 10 & 12 & 14 \\
\hline$>\$ 1 \mathrm{bn}$ & $\cdots$ & $\ldots$ & 1 & 1 & 1 & $\ldots$ & $\ldots$ & 1 \\
\hline Total number & 294 & 396 & 550 & 799 & 1,047 & 1,291 & 1,516 & 1,776 \\
\hline \multicolumn{9}{|l|}{ Estimates of the whole industry } \\
\hline Van Hedge Fund Advisors & 1,977 & 2,373 & 2,848 & 3,417 & 4,100 & 4,700 & 5,100 & 5,500 \\
\hline TASS Research & - & - & - & - & - & - & - & - \\
\hline MAR/Hedge & - & - & - & - & - & - & - & - \\
\hline Hennessee Group & - & 880 & 1,100 & 1,640 & 2,080 & 2,800 & 3,000 & 3,200 \\
\hline \multicolumn{9}{|l|}{ Samples of other databases } \\
\hline MAR/Hedge, CISDM & 163 & 233 & 357 & 542 & 887 & 1,011 & 1,277 & 1,428 \\
\hline
\end{tabular}

Sources: TASS database (30 June 2005 version), TASS Research, Eichengreen et al. (1998), International Monetary Fund (2004),

Financial Stability Forum (2000), Gradante (2003) and Hennessee Group.

Notes: Only funds with reported (estimated) capital under management.

1) September 1999.

2) October 2004 .

\section{Table A2 Number of EU hedge funds}

\begin{tabular}{|c|c|c|c|c|c|c|c|c|}
\hline Strategy, as a $\%$ of total & 1990 & 1991 & 1992 & 1993 & 1994 & 1995 & 1996 & 1997 \\
\hline Directional & 34 & 50 & 53 & 59 & 64 & 61 & 60 & 61 \\
\hline Long/Short Equity Hedge & 3 & 2 & 8 & 12 & 14 & 14 & 18 & 19 \\
\hline Dedicated Short Bias & $\ldots$ & $\ldots$ & $\ldots$ & 1 & 1 & $\ldots$ & $\ldots$ & $\ldots$ \\
\hline Global Macro & 7 & 15 & 14 & 10 & 9 & 11 & 8 & 8 \\
\hline Emerging Markets & 17 & 17 & 16 & 13 & 11 & 11 & 11 & 13 \\
\hline Managed Futures & 7 & 15 & 15 & 24 & 29 & 24 & 22 & 21 \\
\hline Event Driven & 7 & 4 & 3 & 3 & 2 & 2 & 1 & 1 \\
\hline Market Neutral & 3 & 4 & 7 & 6 & 8 & 6 & 5 & 5 \\
\hline Fixed Income Arbitrage & $\ldots$ & 2 & 4 & 3 & 4 & 3 & 2 & 1 \\
\hline Convertible Arbitrage & 3 & 2 & 1 & 2 & 2 & 1 & 2 & 1 \\
\hline Equity Market Neutral & $\cdots$ & $\cdots$ & 1 & 2 & 2 & 1 & 2 & 3 \\
\hline Other & 3 & 2 & 1 & 2 & 1 & 1 & 2 & 2 \\
\hline Fund of Funds & 52 & 39 & 36 & 31 & 26 & 31 & 32 & 31 \\
\hline Size, as a \% of total & 86 & 76 & 80 & 81 & 86 & 88 & 85 & 84 \\
\hline$\$ 100 m-\$ 1 b n$ & $\begin{array}{l}80 \\
14\end{array}$ & 24 & 20 & 19 & 14 & 12 & 15 & 16 \\
\hline$>\$ 1 b n$ & $\ldots$ & $\ldots$ & $\cdots$ & $\ldots$ & $\ldots$ & $\ldots$ & $\ldots$ & 1 \\
\hline Total number & 29 & 46 & 74 & 120 & 168 & 218 & 262 & 291 \\
\hline
\end{tabular}

Source: TASS database (30 June 2005 version).

Note: Only funds with reported (estimated) capital under management. 


\begin{tabular}{|c|c|c|c|c|c|c|c|}
\hline Strategy, as a $\%$ of total & 1998 & 1999 & 2000 & 2001 & 2002 & 2003 & 2004 \\
\hline Directional & 57 & 57 & 57 & 53 & 50 & 48 & 47 \\
\hline Long/Short Equity Hedge & 31 & 33 & 36 & 36 & 34 & 32 & 31 \\
\hline Dedicated Short Bias & 1 & 1 & 1 & 1 & 1 & 1 & 1 \\
\hline Global Macro & 5 & 5 & 4 & 3 & 4 & 4 & 4 \\
\hline Emerging Markets & 8 & 8 & 7 & 5 & 5 & 5 & 5 \\
\hline Managed Futures & 12 & 10 & 8 & 8 & 7 & 6 & 7 \\
\hline Event Driven & 9 & 9 & 9 & 9 & 9 & 9 & 9 \\
\hline Market Neutral & 11 & 12 & 11 & 13 & 15 & 14 & 14 \\
\hline Fixed Income Arbitrage & 4 & 3 & 3 & 3 & 4 & 4 & 5 \\
\hline Convertible Arbitrage & 3 & 3 & 4 & 4 & 4 & 4 & 4 \\
\hline Equity Market Neutral & 4 & 5 & 5 & 6 & 6 & 6 & 5 \\
\hline Other & 3 & 3 & 3 & 3 & 4 & 4 & 4 \\
\hline Fund of Funds & 20 & 20 & 20 & 21 & 22 & 25 & 27 \\
\hline \multicolumn{8}{|l|}{ Size, as a $\%$ of total } \\
\hline$\leq \$ 100 \mathrm{~m}$ & 85 & 83 & 81 & 79 & 77 & 72 & 67 \\
\hline$\$ 100 m-\$ 1 b n$ & 14 & 16 & 18 & 20 & 22 & 26 & 31 \\
\hline$>\$ 1 b n$ & 1 & 1 & $\ldots$ & 1 & 1 & 1 & 2 \\
\hline Total number & 1,969 & 2,212 & 2,418 & 2,697 & 2,939 & 3,156 & 3,264 \\
\hline \multicolumn{8}{|l|}{ Estimates of the whole industry } \\
\hline Van Hedge Fund Advisors & 5,830 & 6,200 & 6,500 & 7,000 & 7,500 & 8,100 & - \\
\hline TASS Research & - & - & - & - & - & 6,700 & - \\
\hline MAR/Hedge & 3,000 & 3,000 & - & - & - & - & - \\
\hline Hennessee Group & 3,500 & 4,000 & 4,800 & 5,500 & 5,700 & 7,000 & 8,050 \\
\hline \multicolumn{8}{|l|}{ Samples of other databases } \\
\hline MAR/Hedge, CISDM & 1,385 & $1,256^{1)}$ & - & - & - & 1,862 & $2,000^{2)}$ \\
\hline
\end{tabular}

\section{Table A2 Number of EU hedge funds (cont'd)}

\begin{tabular}{|c|c|c|c|c|c|c|c|}
\hline Strategy, as a $\%$ of total & 1998 & 1999 & 2000 & 2001 & 2002 & 2003 & 2004 \\
\hline Directional & 59 & 61 & 60 & 55 & 51 & 49 & 48 \\
\hline Long/Short Equity Hedge & 20 & 27 & 31 & 32 & 31 & 30 & 29 \\
\hline Dedicated Short Bias & $\ldots$ & & $\ldots$ & $\ldots$ & $\ldots$ & $\ldots$ & $\ldots$ \\
\hline Global Macro & 9 & 7 & 6 & 6 & 6 & 6 & 5 \\
\hline Emerging Markets & 12 & 11 & 10 & 7 & 6 & 6 & 5 \\
\hline Managed Futures & 18 & 16 & 13 & 10 & 8 & 8 & 9 \\
\hline Event Driven & 3 & 3 & 4 & 4 & 4 & 4 & 4 \\
\hline Market Neutral & 5 & 7 & 7 & 11 & 13 & 13 & 12 \\
\hline Fixed Income Arbitrage & 2 & 2 & 2 & 3 & 3 & 3 & 4 \\
\hline Convertible Arbitrage & 1 & 1 & 2 & 2 & 3 & 3 & 2 \\
\hline Equity Market Neutral & 2 & 4 & 4 & 6 & 7 & 7 & 6 \\
\hline Other & 3 & 4 & 3 & 4 & 3 & 3 & 3 \\
\hline Fund of Funds & 30 & 26 & 26 & 25 & 29 & 31 & 33 \\
\hline Size, as a $\%$ of total & & & & & & & \\
\hline$\leq \$ 100 \mathrm{~m}$ & 81 & 81 & 80 & 77 & 72 & 65 & 59 \\
\hline$\$ 100 m-\$ 1 b n$ & 18 & 18 & 19 & 22 & 27 & 34 & 39 \\
\hline$>\$ 1 \mathrm{bn}$ & 1 & 1 & 1 & 1 & 1 & 2 & 2 \\
\hline Total number & 328 & 397 & 464 & 569 & 669 & 773 & 836 \\
\hline
\end{tabular}




\section{Table A3 Capital under management of hedge funds}

\begin{tabular}{|c|c|c|c|c|c|c|c|c|}
\hline \multicolumn{9}{|l|}{ (USD billions) } \\
\hline Strategy, as a $\%$ of total & 1990 & 1991 & 1992 & 1993 & 1994 & 1995 & 1996 & 1997 \\
\hline Directional & 59 & 61 & 62 & 59 & 60 & 60 & 55 & 52 \\
\hline Long/Short Equity Hedge & 24 & 23 & 22 & 27 & 24 & 29 & 29 & 27 \\
\hline Dedicated Short Bias & 3 & 1 & 1 & 1 & 1 & 1 & 1 & 1 \\
\hline Global Macro & 19 & 25 & 30 & 17 & 18 & 16 & 11 & 10 \\
\hline Emerging Markets & 3 & 4 & 4 & 8 & 11 & 10 & 10 & 11 \\
\hline Managed Futures & 11 & 8 & 6 & 6 & 6 & 5 & 4 & 3 \\
\hline Event Driven & 13 & 12 & 10 & 10 & 10 & 11 & 11 & 12 \\
\hline \multirow{4}{*}{$\begin{array}{l}\text { Market Neutral } \\
\text { Fixed Income Arbitrage } \\
\text { Convertible Arbitrage } \\
\text { Equity Market Neutral }\end{array}$} & 6 & 6 & 9 & 11 & 9 & 11 & 14 & 16 \\
\hline & 3 & 3 & 3 & 4 & 4 & 5 & 7 & 8 \\
\hline & 2 & 2 & 5 & 5 & 4 & 4 & 5 & 5 \\
\hline & 1 & 1 & 1 & 1 & 1 & 2 & 3 & 3 \\
\hline Other & $\ldots$ & $\ldots$ & $\ldots$ & 1 & 1 & 2 & 3 & 4 \\
\hline Fund of Funds & 23 & 20 & 18 & 19 & 20 & 17 & 17 & 16 \\
\hline \multicolumn{9}{|l|}{ Size, as a $\%$ of total } \\
\hline$\leq \$ 100 \mathrm{~m}$ & 42 & 36 & 31 & 31 & 31 & 36 & 34 & 29 \\
\hline$\$ 100 m-\$ 1 b n$ & 58 & 58 & 46 & 56 & 52 & 49 & 53 & 56 \\
\hline$>\$ 1 \mathrm{bn}$ & $\ldots$ & 6 & 23 & 13 & 17 & 14 & 13 & 15 \\
\hline Total capital & 11 & 18 & 28 & 43 & 55 & 63 & 83 & 122 \\
\hline \multicolumn{9}{|l|}{ Estimates of the whole industry } \\
\hline Van Hedge Fund Advisors & 67 & 94 & 120 & 172 & 189 & 217 & 261 & 295 \\
\hline TASS Research & - & - & - & - & - & - & - & - \\
\hline MAR/Hedge & - & - & - & - & - & - & - & 145 \\
\hline \multirow{2}{*}{\multicolumn{9}{|c|}{$\begin{array}{l}\text { Hennessee Group } \\
\text { Samples of other databases }\end{array}$}} \\
\hline & & & & & & & & \\
\hline MAR/Hedge, CISDM & 10 & 15 & 23 & 43 & 70 & 71 & 99 & 132 \\
\hline
\end{tabular}

Sources: TASS database (30 June 2005 version), TASS Research, Eichengreen et al. (1998), International Monetary Fund (2004), Financial Stability Forum (2000), Gradante (2003) and Hennessee Group.

Notes: Only funds with reported (estimated) capital under management.

1) September 1999.

2) October 2004

\section{Table A4 Capital under management of EU hedge funds}

\begin{tabular}{|c|c|c|c|c|c|c|c|c|}
\hline \multicolumn{9}{|l|}{ (USD billions) } \\
\hline Strategy, as a $\%$ of total & 1990 & 1991 & 1992 & 1993 & 1994 & 1995 & 1996 & 1997 \\
\hline Directional & 52 & 45 & 44 & 49 & 51 & 50 & 53 & 56 \\
\hline Long/Short Equity Hedge & 4 & 3 & 7 & 13 & 7 & 10 & 15 & 14 \\
\hline Dedicated Short Bias & $\ldots$ & $\ldots$ & $\ldots$ & $\ldots$ & $\ldots$ & $\ldots$ & 1 & $\ldots$ \\
\hline Global Macro & 34 & 26 & 21 & 16 & 16 & 11 & 11 & 15 \\
\hline Emerging Markets & 14 & 15 & 13 & 18 & 23 & 23 & 22 & 22 \\
\hline Managed Futures & 1 & 1 & 2 & 2 & 4 & 5 & 5 & 5 \\
\hline Event Driven & 7 & 7 & 7 & 5 & 5 & 3 & 1 & 1 \\
\hline Market Neutral & 4 & 14 & 18 & 10 & 9 & 9 & 13 & 9 \\
\hline Fixed Income Arbitrage & $\ldots$ & 10 & 12 & 6 & 7 & 8 & 8 & 6 \\
\hline Convertible Arbitrage & 4 & 4 & 4 & 4 & 1 & 1 & 1 & 1 \\
\hline Equity Market Neutral & $\ldots$ & $\ldots$ & 1 & $\ldots$ & 1 & 1 & 4 & 3 \\
\hline Other & $\cdots$ & $\ldots$ & $\ldots$ & $\cdots$ & $\ldots$ & $\cdots$ & 1 & 2 \\
\hline Fund of Funds & 37 & 34 & 31 & 37 & 35 & 38 & 32 & 32 \\
\hline Size, as a $\%$ of total & & & & & & & & \\
\hline$\leq \$ 100 \mathrm{~m}$ & 38 & 22 & 20 & 19 & 27 & 31 & 29 & 23 \\
\hline$\$ 100 m-\$ 1 b n$ & 62 & 78 & 80 & 81 & 73 & 69 & 71 & 64 \\
\hline$>\$ 1 \mathrm{bn}$ & $\ldots$ & $\ldots$ & $\ldots$ & $\ldots$ & $\ldots$ & $\ldots$ & $\ldots$ & 13 \\
\hline Total capital & 2 & 3 & 4 & 9 & 10 & 11 & 15 & 22 \\
\hline
\end{tabular}

Source: TASS database (30 June 2005 version).

Note: Only funds with reported (estimated) capital under management. 


\begin{tabular}{|c|c|c|c|c|c|c|c|}
\hline (USD billions) & & & & & & & \\
\hline Strategy, as a $\%$ of total & 1998 & 1999 & 2000 & 2001 & 2002 & 2003 & 2004 \\
\hline Directional & 48 & 53 & 48 & 44 & 41 & 41 & 40 \\
\hline Long/Short Equity Hedge & 31 & 38 & 39 & 35 & 30 & 27 & 27 \\
\hline Dedicated Short Bias & 1 & 1 & 1 & 1 & $\ldots$ & $\ldots$ & ... \\
\hline Global Macro & 8 & 6 & 2 & 2 & 3 & 5 & 4 \\
\hline Emerging Markets & 5 & 5 & 4 & 3 & 3 & 5 & 5 \\
\hline Managed Futures & 4 & 3 & 3 & 3 & 4 & 4 & 5 \\
\hline Event Driven & 14 & 13 & 15 & 15 & 13 & 12 & 13 \\
\hline Market Neutral & 17 & 13 & 15 & 18 & 19 & 18 & 16 \\
\hline Fixed Income Arbitrage & 7 & 5 & 4 & 5 & 6 & 6 & 7 \\
\hline Convertible Arbitrage & 5 & 3 & 4 & 5 & 6 & 6 & 5 \\
\hline Equity Market Neutral & 5 & 5 & 6 & 7 & 7 & 5 & 4 \\
\hline Other & 4 & 4 & 5 & 6 & 6 & 6 & 6 \\
\hline Fund of Funds & 17 & 16 & 17 & 18 & 22 & 23 & 25 \\
\hline Size, as a $\%$ of total & & & & & & & \\
\hline$\leq \$ 100 \mathrm{~m}$ & 29 & 28 & 26 & 24 & 23 & 19 & 15 \\
\hline$\$ 100 m-\$ 1 b n$ & 58 & 61 & 66 & 64 & 63 & 64 & 66 \\
\hline$>\$ 1 \mathrm{bn}$ & 12 & 11 & 8 & 12 & 15 & 17 & 20 \\
\hline Total capital & 127 & 157 & 185 & 235 & 270 & 361 & 463 \\
\hline Estimates of the whole industry & & & & & & & \\
\hline Van Hedge Fund Advisors & 311 & 480 & 520 & 600 & 650 & 820 & - \\
\hline TASS Research & - & - & - & - & - & 750 & 975 \\
\hline MAR/Hedge & 175 & 205 & - & - & - & - & - \\
\hline Hennessee Group & 221 & 324 & 408 & 564 & 592 & 795 & $1,000+$ \\
\hline Samples of other databases & & & & & & & \\
\hline MAR/Hedge, CISDM & 128 & $121^{1)}$ & - & - & - & - & $384^{21}$ \\
\hline
\end{tabular}

\section{Table A4 Capital under management of EU hedge funds (cont'd)}

\begin{tabular}{|c|c|c|c|c|c|c|c|}
\hline (USD billions) & & & & & & & \\
\hline Strategy, as a $\%$ of total & 1998 & 1999 & 2000 & 2001 & 2002 & 2003 & 2004 \\
\hline Directional & 53 & 58 & 53 & 50 & 52 & 54 & 50 \\
\hline Long/Short Equity Hedge & 23 & 34 & 38 & 35 & 36 & 32 & 32 \\
\hline Dedicated Short Bias & $\ldots$ & $\ldots$ & $\ldots$ & $\ldots$ & $\ldots$ & $\ldots$ & $\ldots$ \\
\hline Global Macro & 11 & 6 & 4 & 4 & 5 & 7 & 4 \\
\hline Emerging Markets & 10 & 11 & 7 & 6 & 6 & 9 & 7 \\
\hline Managed Futures & 7 & 6 & 4 & 4 & 5 & 6 & 7 \\
\hline Event Driven & 1 & 2 & 5 & 4 & 3 & 3 & 4 \\
\hline Market Neutral & 13 & 12 & 12 & 14 & 14 & 14 & 13 \\
\hline Fixed Income Arbitrage & 8 & 6 & 3 & 3 & 3 & 3 & 6 \\
\hline Convertible Arbitrage & 2 & 1 & 3 & 5 & 5 & 5 & 3 \\
\hline Equity Market Neutral & 3 & 5 & 6 & 6 & 6 & 5 & 4 \\
\hline Other & 3 & 5 & 8 & 9 & 6 & 4 & 4 \\
\hline Fund of Funds & 30 & 23 & 22 & 24 & 26 & 26 & 29 \\
\hline Size, as a $\%$ of total & & & & & & & \\
\hline$\leq \$ 100 \mathrm{~m}$ & 24 & 23 & 23 & 22 & 20 & 15 & 12 \\
\hline$\$ 100 m-\$ 1 b n$ & 68 & 60 & 59 & 63 & 66 & 68 & 69 \\
\hline$>\$ 1 \mathrm{bn}$ & 9 & 18 & 18 & 15 & 14 & 17 & 19 \\
\hline Total capital & 24 & 35 & 42 & 55 & 71 & 104 & 137 \\
\hline
\end{tabular}


Major international initiatives to address concerns related to hedge funds

\begin{tabular}{|c|c|c|c|}
\hline Date & Entity & Report & Description \\
\hline Jan. 1999 & $\begin{array}{l}\text { Basel Committee on } \\
\text { Banking Supervision } \\
\text { (BCBS) }\end{array}$ & $\begin{array}{l}\text { Banks' Interactions with } \\
\text { Highly Leveraged } \\
\text { Institutions (HLIs) } \\
\text { Sound Practices for Banks' } \\
\text { Interactions with HLIs }\end{array}$ & $\begin{array}{l}\text { The aim of the reports was to encourage prudent } \\
\text { management of risks generated from banks' interactions } \\
\text { with highly leveraged institutions. }\end{array}$ \\
\hline Mar. 1999 & $\begin{array}{l}\text { International Swaps and } \\
\text { Derivatives Association } \\
\text { (ISDA) }\end{array}$ & $\begin{array}{l}\text { ISDA } 1999 \text { Collateral } \\
\text { Review }\end{array}$ & $\begin{array}{l}\text { Measures to reduce risks associated with collateralisation } \\
\text { were suggested. }\end{array}$ \\
\hline Mar. 1999 & $\begin{array}{l}\text { Institute of International } \\
\text { Finance (IIF) }\end{array}$ & $\begin{array}{l}\text { Report of the Task Force on } \\
\text { Risk Assessment }\end{array}$ & \\
\hline Apr. 1999 & $\begin{array}{l}\text { US President's Working } \\
\text { Group on Financial } \\
\text { Markets (PWG) }\end{array}$ & $\begin{array}{l}\text { Hedge Funds, Leverage and } \\
\text { the Lessons of LTCM }\end{array}$ & $\begin{array}{l}\text { Review of the near-collapse of LTCM and the analysis of } \\
\text { further sources of remaining systematic vulnerabilities. } \\
\text { Recommendations include increased transparency } \\
\text { through enhanced disclosure of hedge funds. }\end{array}$ \\
\hline June 1999 & $\begin{array}{l}\text { Counterparty Risk } \\
\text { Management Policy } \\
\text { Group I (CRMPG) }\end{array}$ & $\begin{array}{l}\text { Improving Counterparty } \\
\text { Risk Management Practices } \\
\text { (Corrigan report) }\end{array}$ & $\begin{array}{l}\text { The report made recommendations on how to improve } \\
\text { counterparty risk management practices and suggested a } \\
\text { possible format for regulatory reporting relating to HLIs. }\end{array}$ \\
\hline Nov. 1999 & $\begin{array}{l}\text { International } \\
\text { Organization of Securities } \\
\text { Commissions (IOSCO) }\end{array}$ & $\begin{array}{l}\text { Hedge Funds and Other } \\
\text { HLIs }\end{array}$ & $\begin{array}{l}\text { Focus on risk management issues relating to securities } \\
\text { firms and the need for greater transparency in the hedge } \\
\text { fund sector. }\end{array}$ \\
\hline Jan. 2000 & BCBS & $\begin{array}{l}\text { Banks' Interactions with } \\
\text { HLIs: Implementation of } \\
\text { Basel Committee's Sound } \\
\text { Practices Paper }\end{array}$ & $\begin{array}{l}\text { Issues which need further work were identified - for } \\
\text { example, measurement of potential future credit } \\
\text { exposures. }\end{array}$ \\
\hline Feb. 2000 & $\begin{array}{l}\text { A group of five of the } \\
\text { largest independent } \\
\text { hedge fund managers }\end{array}$ & $\begin{array}{l}\text { Sound Practices for Hedge } \\
\text { Fund Managers }\end{array}$ & $\begin{array}{l}\text { Response to PWG Report, addressing the PWG } \\
\text { recommendation to develop and publish sound practices } \\
\text { for risk management and internal controls. }\end{array}$ \\
\hline Apr. 2000 & $\begin{array}{l}\text { Financial Stability } \\
\text { Forum (FSF) }\end{array}$ & $\begin{array}{l}\text { Report of the Working } \\
\text { Group on HLIs }\end{array}$ & $\begin{array}{l}\text { The report concentrated on systemic risk posed by HLIs } \\
\text { and their impact on market dynamics. Measures } \\
\text { enhancing prudent firm behaviour and market discipline } \\
\text { were brought forward. }\end{array}$ \\
\hline Mar. 2001 & BCBS and IOSCO & $\begin{array}{l}\text { Review of Issues Relating } \\
\text { to HLIs }\end{array}$ & $\begin{array}{l}\text { Senior managers have reinforced their oversight of HLI } \\
\text { activities, and information flows from HLI have } \\
\text { improved. Competitive pressures should not erode credit } \\
\text { standards. }\end{array}$ \\
\hline Mar. 2001 & FSF & $\begin{array}{l}\text { Progress in Implementing } \\
\text { the Recommendations of } \\
\text { the Working Group on } \\
\text { HLIs }\end{array}$ & $\begin{array}{l}\text { Strengthened counterparty risk management and } \\
\text { regulatory oversight acknowledged, but counterparty risk } \\
\text { measurement and stress tests need further work. } \\
\text { Disclosure by HLIs has slightly improved, but the } \\
\text { progress remains inconsistent. }\end{array}$ \\
\hline Apr. 2001 & $\begin{array}{l}\text { Multidisciplinary } \\
\text { Working Group on } \\
\text { Enhanced Disclosure }\end{array}$ & $\begin{array}{l}\text { Final Report to BCBS, } \\
\text { Committee on the Global } \\
\text { Financial System (CGFS) } \\
\text { of the G-10 Central Banks, } \\
\text { International Association } \\
\text { of Insurance Supervisors } \\
\text { (IAIS), IOSCO }\end{array}$ & $\begin{array}{l}\text { The report seeks to improve the state of financial } \\
\text { disclosures and to promote a level playing-field in } \\
\text { disclosure for all financial intermediaries, irrespective } \\
\text { of the type of activities. }\end{array}$ \\
\hline Aug. 2002 & $\begin{array}{l}\text { UK's Financial Services } \\
\text { Authority (FSA) }\end{array}$ & $\begin{array}{l}\text { Hedge Funds and the FSA } \\
\text { (Discussion paper No. 16) }\end{array}$ & $\begin{array}{l}\text { The FSA has initiated an evaluation of the current } \\
\text { regulatory framework of hedge fund activities. }\end{array}$ \\
\hline Aug. 2002 & $\begin{array}{l}\text { Alternative Investment } \\
\text { Management Association } \\
\text { (AIMA) }\end{array}$ & $\begin{array}{l}\text { Guide to Sound Practices } \\
\text { for European Hedge Fund } \\
\text { Managers }\end{array}$ & \\
\hline Mar. 2003 & UK's FSA & $\begin{array}{l}\text { Hedge Funds and the FSA: } \\
\text { Feedback Statement on } \\
\text { Discussion Paper No.16 }\end{array}$ & $\begin{array}{l}\text { The decision was that no amendments to the current UK } \\
\text { regulatory framework of hedge fund activities are } \\
\text { required. }\end{array}$ \\
\hline
\end{tabular}


Major international initiatives to address concerns related to hedge funds (cont'd)

\begin{tabular}{|c|c|c|c|}
\hline Date & Entity & Report & Description \\
\hline Sep. 2003 & $\begin{array}{l}\text { Staff Report to US } \\
\text { Securities and Exchange } \\
\text { Commission (SEC) }\end{array}$ & $\begin{array}{l}\text { Implications of the Growth } \\
\text { of Hedge Funds }\end{array}$ & $\begin{array}{l}\text { Concerns about the rapidity of hedge fund industry } \\
\text { growth and its opaqueness led to the proposal to require } \\
\text { hedge fund managers to register with the SEC under the } \\
\text { Investment Advisers Act of } 1940 \text { and to comply with } \\
\text { certain disclosure requirements. }\end{array}$ \\
\hline Aug. 2003 & $\begin{array}{l}\text { Managed Funds } \\
\text { Association (MFA) }\end{array}$ & $\begin{array}{l}\text { Sound Practices for Hedge } \\
\text { Fund Managers: Update }\end{array}$ & $\begin{array}{l}\text { Update of February } 2000 \text { report by five large hedge fund } \\
\text { managers. }\end{array}$ \\
\hline Jan. 2004 & European Parliament & $\begin{array}{l}\text { Resolution on the Future } \\
\text { of Hedge Funds and } \\
\text { Derivatives }\end{array}$ & $\begin{array}{l}\text { The desire to bring offshore hedge funds onshore led to } \\
\text { the proposal to introduce a pan-European, lightly } \\
\text { regulated regime for "sophisticated alternative } \\
\text { investment vehicles", benefiting from a common EU- } \\
\text { wide passport. }\end{array}$ \\
\hline June 2005 & UK's FSA & $\begin{array}{l}\text { Wider-range Retail } \\
\text { Investment Products } \\
\text { (Discussion paper No. 3); } \\
\text { Hedge funds: a Discussion } \\
\text { of Risk and Regulatory } \\
\text { Engagement (Discussion } \\
\text { paper No. 4) }\end{array}$ & $\begin{array}{l}\text { The purpose of DP } 3 \text { is to assess whether the present } \\
\text { regulatory regime that applies to retail investment } \\
\text { products is still appropriate in light of existing/new } \\
\text { products (incl. hedge funds). The aim of DP } 4 \text { is to } \\
\text { identify potential risks posed by hedge funds and to } \\
\text { stimulate debate. }\end{array}$ \\
\hline July 2005 & $\begin{array}{l}\text { Counterparty Risk } \\
\text { Management Policy } \\
\text { Group II (CRMPG) }\end{array}$ & $\begin{array}{l}\text { Toward Greater Financial } \\
\text { Stability: a Private Sector } \\
\text { Perspective }\end{array}$ & Review of the June 1999 report. \\
\hline Aug. 2005 & $\begin{array}{l}\text { Managed Funds } \\
\text { Association (MFA) }\end{array}$ & $\begin{array}{l}\text { Sound Practices for Hedge } \\
\text { Fund Managers }\end{array}$ & $\begin{array}{l}\text { Update and expansion of August } 2003 \text { and February } 2000 \\
\text { reports. }\end{array}$ \\
\hline
\end{tabular}




\section{REFERENCES}

1. Alternative Investment Management Association (2002), "Guide to Sound Practices for European Hedge Fund Managers", August.

2. Asset Management Expert Group (2004), "Financial Services Action Plan: Progress and Prospects, Final Report by the Asset Management Expert Group", May.

3. Atiyah, S. and A. Walters (2004), "Hedge Funds - An Overview", Butterworths Journal of International Banking and Financial Law, May, pp. 173-77.

4. Atkins, P. S. (2004), "Open Meeting to Consider the Registration of Hedge Fund Advisors", speech, 26 October.

5. Avery, H. (2005), "Hedge Funds Register Scorn at SEC Ruling", Euromoney, March, pp. 36-39.

6. Barclays Capital (2003), "Observations on the Rapid Growth of the Hedge Fund Industry", December.

7. Basel Committee on Banking Supervision (1999a), "Banks' Interactions with Highly Leveraged Institutions", January.

8. Basel Committee on Banking Supervision (1999b), "Sound Practices for Banks' Interactions with Highly Leveraged Institutions", January.

9. Basel Committee on Banking Supervision (2000), "Banks' Interactions with Highly Leveraged Institutions: Implementation of the Basel Committee's Sound Practices Paper", January.

10. Basel Committee on Banking Supervision and the International Organization of Securities Commissions (2001), "Review of Issues Relating to Highly Leveraged Institutions (HLIs)", March.

11. Bernstein, P. J. (2002), “The Hedge Fund Mystique”, Journal of Accountancy, May, p. 55.

12. Bradbery, A. (2004), "U.K. Pension Managers Turn to Hedge Funds", Wall Street Journal, 18 August.

13. British Bankers' Association (2004), “Credit Derivatives Report-2003/04”, September.

14. Chan, N., M. Getmansky, S. M. Haas and A. W. Lo (2005), "Systemic Risk and Hedge Funds", NBER, WP 11200, March.

15. Counterparty Risk Management Policy Group (1999), "Improving Counterparty Risk Management Practices", June.

16. Counterparty Risk Management Policy Group (2005), "Toward Greater Financial Stability: a Private Sector Perspective", July. 
17. Deutsche Bank (2004), "2004 Alternative Investment Survey. Hedge Funds: Full Speed Ahead", February.

18. Deutsche Bank (2005), “2005 Alternative Investment Survey”, July.

19. Economist (2005), "The New Money Men”, 19 February, pp. 59-61.

20. Eichengreen, B., D. Mathieson, B. Chadha, A. Jansen, L. Kodres and S. Sharma (1998), "Hedge Funds and Financial Market Dynamics", International Monetary Fund Occasional Paper, No 166, May.

21. Eichengreen, B. and D. Mathieson (1999), "Hedge Funds: What Do We Really Know?", Economic Issues, No 19, International Monetary Fund, September.

22. EuroHedge (2004), "Chasing Pack Continue to Close Gap on the Big Two", March, pp. 19-21.

23. European Central Bank (2004), Financial Stability Review, December.

24. European Central Bank (2005), Financial Stability Review, June.

25. European Commission (2005a), "Green Paper on Financial Services Policy (2005-2010)", $\operatorname{COM}(2005)$ 177, May.

26. European Commission (2005b), "Green Paper on the Enhancement of the EU Framework for Investment Funds", $\operatorname{COM}(2005) 314$, July.

27. European Parliament (2003), "Report on the Future of Hedge Funds and Derivatives", Committee on Economic and Monetary Affairs, 17 December.

28. European Parliament (2004), "Resolution on the Future of Hedge Funds and Derivatives", January.

29. Financial Stability Forum (2000), "Report of the Working Group on Highly Leveraged Institutions", April.

30. Financial Stability Forum (2002), "Recommendations and Concerns Raised by Highly Leveraged Institutions: An Assessment", March.

31. Fitch Ratings (2005), "Hedge Funds: An Emerging Force in the Global Credit Markets”, July.

32. Getmansky, M., A. W. Lo and I. Makarov (2003), "Serial Correlation and Illiquidity in Hedge Fund Returns", April.

33. Gradante, C. J. (2003), "Comments of Hennessee Group LLC for the U.S. SEC Roundtable on Hedge Funds", May.

34. Haigh, M. S., J. Hranaiova and J. A. Overdahl (2005), "Price Dynamics, Price Discovery and Large Futures Trader Interactions in the Energy Complex", CFTC, April. 
35. Hedges, J. R. IV (2004a), "Size vs. Performance in the Hedge Fund Industry", Journal of Financial Transformation, Vol. 10, Capco Institute, April.

36. Hedges, J. R. IV (2004b), "Hedge Fund Indices", Journal of Financial Transformation, Vol. 11, Capco Institute, August.

37. Institute of International Finance (1999), "Report of the Task Force on Risk Assessment".

38. International Financial Services, London (2004), "Hedge Funds", City Business Series, June.

39. International Financial Services, London (2005), "Hedge Funds", City Business Series, April.

40. International Monetary Fund (2004), “Global Financial Stability Report”, September.

41. International Organization of Securities Commissions (1999), "Hedge Funds and Other Highly Leveraged Institutions", November.

42. International Organization of Securities Commissions (2003), "Regulatory and Investor Protection Issues Arising from the Participation by Retail Investors", February.

43. International Swaps and Derivatives Association (1999), "ISDA 1999 Collateral Review", March.

44. Joint Forum (2004), "Financial Disclosure in the Banking, Insurance and Securities Sectors: Issues and Analysis", May.

45. Kundro, C. and S. Feffer (2004), "Valuation Issues and Operational Risk in Hedge Funds", Journal of Financial Transformation, Vol. 11, Capco Institute, August, pp. 41-47.

46. Maiden, B. (2004), "SEC Faces Challenges to Authority on Fund Rules", International Financial Law Review, October.

47. Malkiel, B. G. and A. Saha (2004), “Hedge Funds: Risk and Return”, October.

48. Managed Funds Association (2000), "Sound Practices for Hedge Fund Managers”, February.

49. Managed Funds Association (2003), "Sound Practices for Hedge Fund Managers: Update", August.

50. Managed Funds Association (2005), "MFA's 2005 Sound Practices for Hedge Fund Managers", August.

51. McGuire, P., E. Remolona and K. Tsatsaronis (2005), “Time-varying exposures and leverage in hedge funds", BIS Quarterly Review, March.

52. Multidisciplinary Working Group on Enhanced Disclosure (2001), "Final Report to BCBS, CGFS, IAIS and IOSC", April. 
53. Osterberg, W. and J. Thomson (1999), "The Truth about Hedge Funds", Federal Reserve Bank of Cleveland, May.

54. Persaud, A. (2001), "The Puzzling Decline in Financial Market Liquidity" and "Sending the Herd Off the Cliff Edge: the Disturbing Interaction between Herding and Market-Sensitive Risk Management Practices", published in "Market Liquidity: Proceedings of a Workshop Held at the BIS", BIS Papers, No. 2, April.

55. PricewaterhouseCoopers (2004a), “Investment Management Perspectives”, March.

56. PricewaterhouseCoopers (2004b), "The Regulation and Distribution of Hedge Funds in Europe, Changes and Challenges: Update", May.

57. Pütz, A. and C. Schmies (2004), "Hedge Fund Regulation in Germany", Journal of International Banking Law and Regulation, No 5, pp. 177-83.

58. Radley \& Associates (2005), "The Hedge Fund Industry and the City", June.

59. Sants, H. (2004), "FSA's Outlook on Asset Management Risks, Priorities and Challenges", speech, 28 September.

60. Securities and Exchange Commission (2003), "Implications of the Growth of Hedge Funds", staff report to the United States Securities and Exchange Commission, September.

61. Securities and Exchange Commission (2004), "Registration under the Advisers Act of Certain Hedge Fund Advisers - 17 CFR Parts 275 and 279", Federal Register, Vol. 69, No 144, 28 July.

62. Strategic Financial Solutions (2004), "Database Study 2004: Executive Summary", 10 November.

63. Trichet, J.-C. (2005), "European Financial Integration: the Views of the ECB", Speech at the EUROPLACE, International Financial Forum, 6 July.

64. UK's Financial Services Authority (2002), "Hedge Funds and the FSA", Discussion Paper, No 16, August.

65. UK's Financial Services Authority (2003), "Hedge Funds and the FSA: Feedback Statement on Discussion Paper 16", March.

66. UK's Financial Services Authority (2005a), "Wider-range Retail Investment Products", Discussion Paper, No. 3, June.

67. UK's Financial Services Authority (2005b), "Hedge Funds: a Discussion of Risk and Regulatory Engagement", Discussion Paper, No. 4, June.

68. US President's Working Group on Financial Markets (1999), "Hedge Funds, Leverage, and the Lessons of Long-term Capital Management", April. 
69. US Securities and Exchange Commission (2003), "Implications of the Growth of Hedge Funds", September.

70. Vaughan, D. A. (2003), "Selected Definitions of Hedge Fund", comments for the US SEC Roundtable on Hedge Funds, 14-15 May.

71. Wolcott, R. (2004), "Insurers Consider Alternative Route”, Risk, August, pp. 23-25. 
Absolute return - portfolio return without subtracting any benchmark return.

Alpha - return associated with active asset management. Also referred to as non-systematic risk or specific risk, as opposed to systemic or overall market risk.

Alternative investments - a broad category of investments, other than stocks and bonds, including venture capital, private equity, real estate, precious metals, collectibles and hedge funds.

Arbitrage - in theory, a transaction that produces risk-free profit by exploiting mis-priced securities or any other assets while hedging all risk. In practice, arbitrage strategies do not eliminate all risk and do entail some risk of loss or uncertainty about total profits.

Beta - broadly denotes volatility and returns associated with general or market-wide risks. A measure of the volatility relative to the overall market.

Carry trade - involves borrowing funds in a low-yielding currency and investing in a highyielding one, or purchasing one security with more yield, or carry, than that which is sold.

Crowded trade - a crowded trade could be defined as multiple parties entering into correlated trading strategies across one or more markets, where the aggregate volume of trades in the market(s) is sufficient to constrain the ability of traders to exit from the position on a simultaneous basis without significantly impacting prevailing prices.

Derivative - a financial instrument whose value depends upon the value of an underlying security. Options, forwards and futures are examples of derivatives.

Domicile of a fund - the location of the legal entity of the fund.

Fund of hedge funds - a fund that invests in other hedge funds for diversification.

Hedge fund - a fund, whose managers generally have no or very limited restrictions on the use of various active investment strategies to achieve positive absolute returns, and receive performance-related fees. Such strategies often involve leverage, derivatives, long and short positions in securities or any other assets in a wide range of markets.

Herding - A situation in which traders emulate or follow the actions of other traders.

Hurdle rate - the minimum return that must be generated before fund managers may receive any performance allocation.

Leverage - economic (debt) leverage is associated with increased assets under management, whereas financial (investment) leverage refers to making investments on margin, where the cost of investment is less than the exposure it generates (e.g. through the use of financial derivatives).

Lock-up period - the time during which an investor cannot withdraw invested money. 
Management fee - an annual fee calculated as a percentage of average capital under management.

Performance fee - the percentage that the hedge fund manager takes of the return of the fund.

Short-selling - the sale of borrowed assets that a seller does not own.

VaR (Value at Risk) - the estimated maximum potential loss to a portfolio over a given time period at a given level of confidence. For example, if a ten-day VaR at 99 confidence level is $€ 100,000$, then we can conclude that $99 \%$ of the time the portfolio will not decline more than $€ 100,000$ in value within 10 days.

Watermark - a fund valuation below which performance fees are not paid. With a high watermark, performance (incentive) fees are paid only if cumulative performance recovers any past shortfalls. For example, a hedge fund manager who loses in the first year and then merely regains that loss in the second year will not receive an incentive payment for the second year's gain.

Wrappers - performance-linked instruments, including unit-linked insurance policies and structured notes, which mimic the performance of a hedge fund. 


\section{EUROPEAN CENTRAL BANK}

OCCASIONAL PAPER SERIES

1 "The impact of the euro on money and bond markets" by J. Santillán, M. Bayle and C. Thygesen, July 2000.

2 "The effective exchange rates of the euro" by L. Buldorini, S. Makrydakis and C. Thimann, February 2002.

3 "Estimating the trend of M3 income velocity underlying the reference value for monetary growth" by C. Brand, D. Gerdesmeier and B. Roffia, May 2002.

4 "Labour force developments in the euro area since the $1980 \mathrm{~s}$ " by V. Genre and R. Gómez-Salvador, July 2002.

5 "The evolution of clearing and central counterparty services for exchange-traded derivatives in the United States and Europe: a comparison" by D. Russo, T. L. Hart and A. Schönenberger, September 2002.

6 "Banking integration in the euro area" by I. Cabral, F. Dierick and J. Vesala, December 2002.

7 "Economic relations with regions neighbouring the euro area in the "Euro Time Zone"" by F. Mazzaferro, A. Mehl, M. Sturm, C. Thimann and A. Winkler, December 2002.

8 "An introduction to the ECB's survey of professional forecasters" by J. A. Garcia, September 2003.

9 "Fiscal adjustment in 1991-2002: stylised facts and policy implications" by M. G. Briotti, February 2004.

10 "The acceding countries' strategies towards ERM II and the adoption of the euro: an analytical review" by a staff team led by P. Backé and C. Thimann and including O. Arratibel, O. Calvo-Gonzalez, A. Mehl and C. Nerlich, February 2004.

11 "Official dollarisation/euroisation: motives, features and policy implications of current cases" by A. Winkler, F. Mazzaferro, C. Nerlich and C. Thimann, February 2004.

12 "Understanding the impact of the external dimension on the euro area: trade, capital flows and other international macroeconomic linkages" by R. Anderton, F. di Mauro and F. Moneta, March 2004.

13 "Fair value accounting and financial stability" by a staff team led by A. Enria and including L. Cappiello, F. Dierick, S. Grittini, A. Maddaloni, P. Molitor, F. Pires and P. Poloni, April 2004.

14 "Measuring Financial Integration in the Euro Area" by L. Baele, A. Ferrando, P. Hördahl, E. Krylova, C. Monnet, April 2004. 
15 "Quality adjustment of European price statistics and the role for hedonics" by H. Ahnert and G. Kenny, May 2004.

16 "Market dynamics associated with credit ratings: a literature review" by F. Gonzalez, F. Haas, R. Johannes, M. Persson, L. Toledo, R. Violi, M. Wieland and C. Zins, June 2004.

17 “Corporate 'Excesses' and financial market dynamics” by A. Maddaloni and D. Pain, July 2004.

18 "The international role of the euro: evidence from bonds issued by non-euro area residents" by A. Geis, A. Mehl and S. Wredenborg, July 2004.

19 "Sectoral specialisation in the EU a macroeconomic perspective" by MPC task force of the ESCB, July 2004.

20 "The supervision of mixed financial services groups in Europe" by F. Dierick, August 2004.

21 "Governance of securities clearing and settlement systems" by D. Russo, T. Hart, M. C. Malaguti and C. Papathanassiou, October 2004.

22 "Assessing potential output growth in the euro area: a growth accounting perspective" by A. Musso and T. Westermann, January 2005.

23 "The bank lending survey for the euro area" by J. Berg, A. van Rixtel, A. Ferrando, G. de Bondt and S. Scopel, February 2005.

24 "Wage diversity in the euro area: an overview of labour cost differentials across industries" by V. Genre, D. Momferatou and G. Mourre, February 2005.

25 "Government debt management in the euro area: recent theoretical developments and changes in practices" by G. Wolswijk and J. de Haan, March 2005.

26 "The analysis of banking sector health using macro-prudential indicators" by L. Mörttinen, P. Poloni, P. Sandars and J. Vesala, March 2005.

27 "The EU budget - how much scope for institutional reform?" by H. Enderlein, J. Lindner, O. Calvo-Gonzalez, R. Ritter, April 2005.

28 "Reforms in selected EU network industries" by R. Martin, M. Roma, I. Vansteenkiste, April 2005.

29 "Wealth and asset price effects on economic activity", by F. Altissimo, E. Georgiou, T. Sastre, M. T. Valderrama, G. Sterne, M. Stocker, M. Weth, K. Whelan, A. Willman, June 2005.

30 "Competitiveness and the export performance of the euro area", by a Task Force of the Monetary Policy Committee of the European System of Central Banks, June 2005. 
31 "Regional monetary integration in the member states of the Gulf Cooperation Council (GCC)" by M. Sturm and N. Siegfried, June 2005.

32 "Managing Financial Crises in Emerging Market Economies: Experience with the Involvement of Private Sector Creditors", by an International Relations Committee task force, July 2005.

33 "Integration of securities market infrastructures in the euro area", by H. Schmiedel, A. Schönenberger, July 2005.

34 "Hedge funds and their implications for financial stability", by T. Garbaravicius and F. Dierick, August 2005. 

